INTERNATIONAL MONETARY FUND

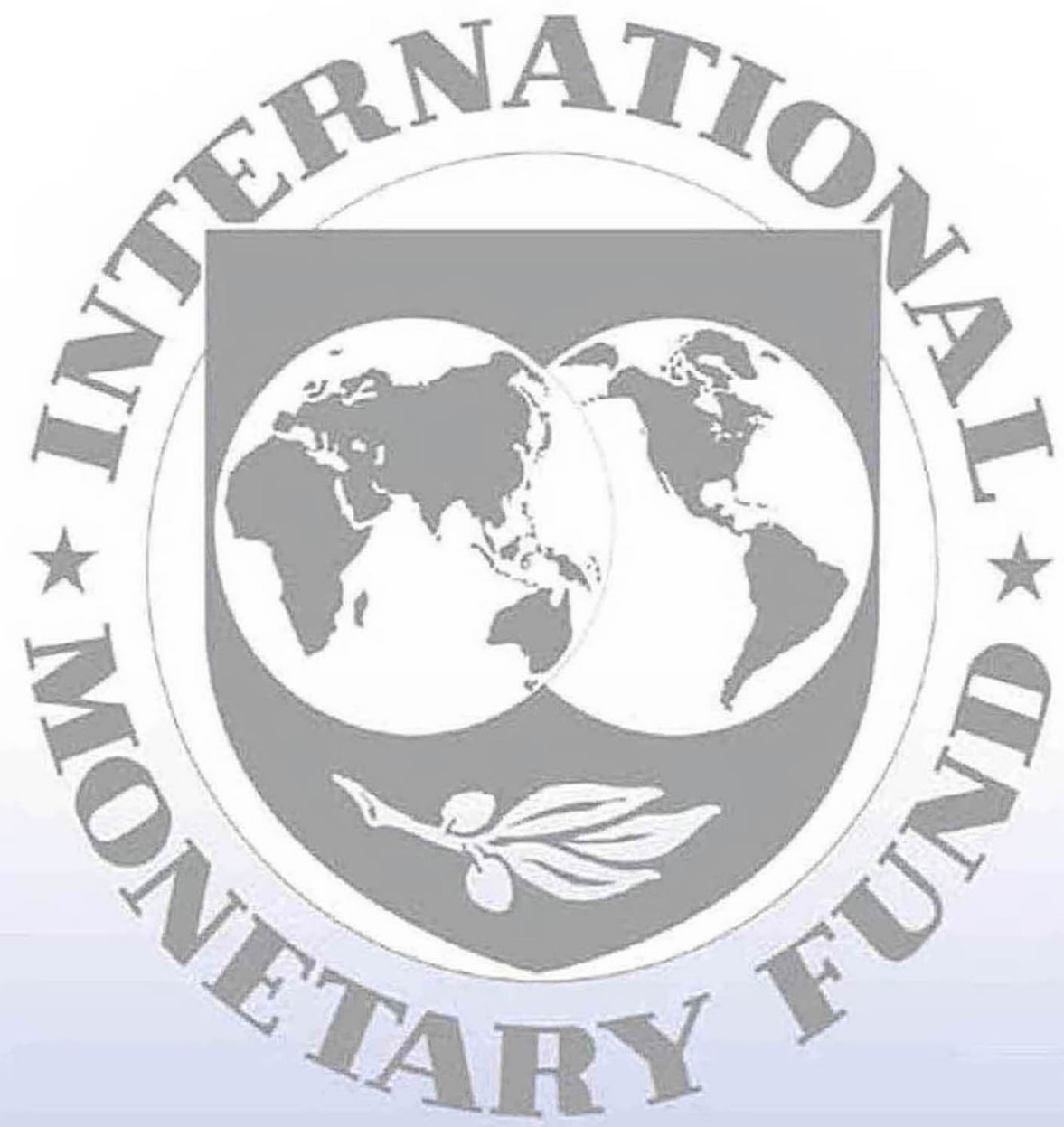

Staff

Country

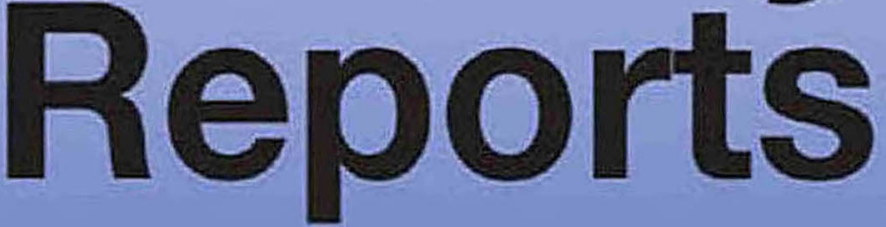




\title{
Burkina Faso: Staff Report for the 2011 Article IV Consultation and the Third Review Under the Extended Credit Facility-Staff Report; Staff Supplement; Public Information Notice and Press Release on the Executive Board Discussion; and Statement by the Executive Director for Burkina Faso
}

Under Article IV of the IMF's Articles of Agreement, the IMF holds bilateral discussions with members, usually every year. In the context of a combined discussion of the Staff Report for the 2011 Article IV Consultation with Burkina Faso and the Third Review Under the Extended Credit Facility, the following documents have been released and are included in this package:

- The staff report for the combined Staff Report for the 2011 Article IV Consultation and the Third Review Under the Extended Credit Facility, prepared by a staff team of the IMF, following discussions that ended on October 14, 2011, with the officials of Burkina Faso on economic developments and policies. Based on information available at the time of these discussions, the staff report was completed on December 8, 2011. The views expressed in the staff report are those of the staff team and do not necessarily reflect the views of the Executive Board of the IMF.

- $\quad$ A Joint World Bank/IMF Debt Sustainability Analysis

A Public Information Notice (PIN) and Press Release, summarizing the views of the Executive Board as expressed during its December 21, 2011, discussion of the staff report on issues related to the Article IV consultation and the IMF arrangement, respectively.

- $\quad$ A statement by the Executive Director for Burkina Faso.

The documents listed below have been or will be separately released.

Letter of Intent sent to the IMF by the authorities of Burkina Faso*

Memorandum of Economic and Financial Policies by the authorities of

Burkina Faso*

Technical Memorandum of Understanding*

*Also included in Staff Report

The policy of publication of staff reports and other documents allows for the deletion of market-sensitive information.

Copies of this report are available to the public from

International Monetary Fund • Publication Services

$70019^{\text {th }}$ Street, N.W. • Washington, D.C. 20431

Telephone: (202) 623-7430 • Telefax: (202) 623-7201

E-mail: publications@imf.org Internet: http://www.imf.org

\author{
International Monetary Fund \\ Washington, D.C.
}


INTERNATIONAL MONETARY FUND

BURKINA FASO

\section{Staff Report for the 2011 Article IV Consultation and Third Review Under the Extended Credit Facility}

Prepared by the African Department

(In collaboration with other departments)

Approved by Michael Atingi-Ego and Thomas Dorsey

December 8, 2011

Mission: Discussions took place in Ouagadougou during September 29-October 14, 2011 for the 2011 Article IV Consultation and the third review under the Extended Credit Facility. The team comprised Ms. Kabedi-Mbuyi (head); Ms. Diouf; Ms. Adenauer (resident representative), and Messrs. Gueye and van Houtte (All AFR). The team held discussions with Ministers Lucien Marie Bembamba (Economy and Finance), Sungalo Ouattara (Public Works), Lamoussa Kaboré (Mining), Arthur Kafando (Commerce), Jean Bertin Ouédraogo (Infrastructure), and Soungalo Appolinaire Ouattara (Civil Service), Mr. Francois M.S. Zoundi (Deputy Minister in Charge of Budget), Mr. Bolo Sanou (National Director of the regional central bank), and other senior officials. Mr. Tall (OED) participated in policy discussions.

Program review. Performance under the program was satisfactory despite a difficult social environment. At end-June 2011, all quantitative performance criteria were met, one indicative target was missed, and most structural benchmarks were observed.

Exchange system: Burkina Faso is a member of the West African Economic and Monetary Union (WAEMU). As such, it has accepted the obligations under Article VIII, Sections 2, 3, and 4 of the IMF Articles of Agreement, and has maintained an exchange system free of restrictions on payments and transfers for current international transactions. The WAEMU common currency is the CFA franc, pegged to the euro at a fixed rate; its monetary and exchange rate policies are conducted by a common central bank.

Data provision: Burkina Faso participates in the General Data Dissemination System (GDDS). Despites some weaknesses, data provision is timely and broadly adequate for surveillance.

Outreach: The team met with representatives of the donor community, the private sector, and the media; and organized a seminar on debt sustainability, competitiveness, and the macroeconomic impact of aid scaling-up for Burkina Faso. 
Acronyms

Executive Summary .$\underline{5}$

I. Introduction $\underline{6}$

II. Overview and Surveillance Issues.

A. Strong Growth despite a Narrow Productive Base ............................................. $\underline{6}$

B. Inflation Is Moderate

C. External Position - Vulnerability to Exogenous Shocks

D. The Financial Sector-Sound with Shallow Financial Intermediation ................... 9

E. Fiscal Policy—Sustained Consolidation Efforts ........................................... 13

III. Medium-Term Outlook

IV. Policy Discussions

A. Supporting Fiscal Sustainability …….................................................... $\frac{15}{16}$

B. Strengthening Debt Policy and Management Capacity........................................ $\frac{16}{19}$

C. Enhancing Growth Prospects ................................................................... $\frac{19}{19}$

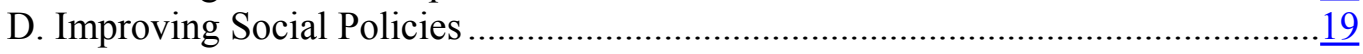

V. Program Performance and Policy for the Rest of $2011-12$.........................................22

VI. Staff Appraisal ................................................................................................... 24

Tables

1. Selected Economic and Financial Indicators, 2008-16 .........................................

2. Balance of Payments, 2008-16 ...................................................................... $\frac{27}{28}$

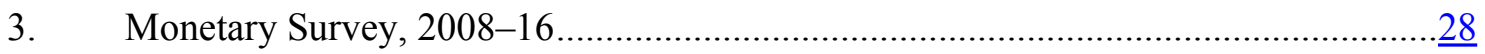

4. Consolidated Operations of the Central Government, 2008-16 ...............................29

5. Indicators of Capacity to Repay the Fund, 2009-19 ...........................................

6. Schedule of Disbursements Under the ECF Arrangement, 2010-13 .........................

7. Poverty-Reducing Social Expenditures, 2001-11 .............................................33

8. Selected Indicators on Millennium Goals, 1990-2008 ...........................................

Boxes

1. Status of Policy Recommendations from the 2009 Article IV Consultation ................

2. Recent Developments in the Financial Sector .....................................................10

3. Progress in Implementation of Key 2008 FSAP Recommendations ..........................11

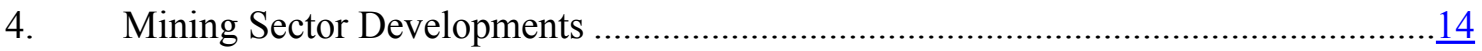


Figures

1. Indicators of Public and Publicly Guaranteed External Debt Under Alternative Scenarios, 2011-2031 ................................................................................. 18

2. Burkina Faso and Sub-Saharan Africa-Doing Business Indicator Rankings ............ $\underline{20}$

3. Selected Millennium Development Goals Indicators ..............................................21

\section{Appendices}

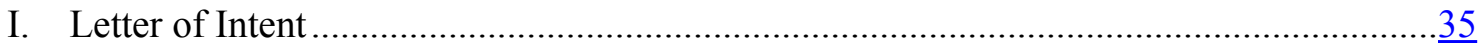

Attachment I. Memorandum of Economic and Financial Policies for 2010-13 ......... 37

Attachment II. Technical Memorandum of Understanding ..................................... 47

II. Exchange Rate Assessment .........................................................................

III. Public Investment Scaling-Up, Growth and Debt Sustainability in Burkina Faso ............ $\underline{63}$ 


\section{List of Acronyms}

$\begin{array}{ll}\text { BCEAO } & \text { Central Bank of West African States } \\ \text { BIC } & \text { tax on industrial and commercial profits } \\ \text { GNF } & \text { goods and nonfactor services } \\ \text { CPIA } & \text { Country Policy and Institutional Assessment } \\ \text { DeMPA } & \text { Debt Management Performance Assessment } \\ \text { IGF } & \text { Inspection Générale des Finances (General Finance Inspection) } \\ \text { LTO } & \text { large taxpayer office } \\ \text { MCC } & \text { Millennium Challenge Corporation } \\ \text { MFIs } & \text { microfinance Institutions } \\ \text { MEFP } & \text { Memorandum of Economic and Financial Policies } \\ \text { MTDS } & \text { Medium-Term Debt Strategy } \\ \text { MTO } & \text { medium taxpayer office } \\ \text { PV } & \text { present value } \\ \text { OHADA } & \text { Organization for the Harmonization of Business Law in Africa } \\ \text { PC } & \text { performance criterion } \\ \text { PFM } & \text { public financial management } \\ \text { PRSP } & \text { Poverty Reduction Strategy Paper } \\ \text { PRSC } & \text { Poverty Reduction and Structural Credit } \\ \text { REER } & \text { real effective exchange rate } \\ \text { SCADD } & \text { Stratégie pour une Croissance Accélérée et pour le Développement } \\ & \text { Durable (Strategy for Accelerated Growth and Sustainable } \\ \text { SSA } & \text { Development) } \\ \text { SOFITEX } & \text { sub-Saharan Africa } \\ \text { SONABHY } & \text { Société Burkinabè des Fibres Textiles (the largest cotton ginning } \\ \text { VAT } & \text { Sompany) } \\ \text { WAEMU } & \text { value-added tax } \\ & \text { West African Economic and Monetary Union } \\ & \end{array}$




\section{Executive Summary}

\section{Macroeconomic developments are positive}

The impact of adverse shocks in the earlier part of 2011 was minimal on the main sectors driving economic growth, and price pressures have subsided. Consequently, real GDP growth is expected to be in line with projections, and inflation to be moderate in 2011-12. The external current account (excluding official transfers) improved in 2010 thanks to higher gold and cotton prices, and a significant increase in gold production. It is forecast to deteriorate in 2011, mostly because of the projected increase in imports demand, partly owing to higher global oil prices. Fiscal policy has remained prudent, despite emergency measures to address the impact of adverse shocks. Mediumterm prospects are promising, reflecting the authorities' resolve to maintain the momentum of structural reforms and scale up investment; and the projected good performance in agriculture, cotton, mining, and services sectors. There are, however, downside risks to the outlook, mainly related to a potential downturn in the global economy and unfavorable weather conditions.

\section{Performance under the program has been good despite the impact of the social turmoil}

At end-June 2011, all quantitative performance criteria were met, the indicative target on pro-poor spending was not observed, partly because of the impact of social turmoil on budget execution; and most structural benchmarks were observed.

Staff recommends the completion of the third review under the Extended Credit Facility arrangement based on the strength of the program, and the authorities' policy commitments in the attached Letter of Intent.

\section{Key policy challenges}

Burkina Faso's main economic challenge is to increase and sustain economic growth to levels compatible with a significant reduction in poverty, while maintaining macroeconomic stability and supporting long-term debt sustainability.

\section{Key recommendations}

- Maintain a prudent fiscal policy stance and strengthen revenue mobilization to safeguard medium-term fiscal objectives.

- $\quad$ Enhance debt policy and management capacity, and maintain a prudent borrowing policy to support long-term debt sustainability.

- $\quad$ Promote economic diversification, and deepen structural reforms to enhance prospects for broad-based growth and poverty reduction.

- Improve social policies, and develop comprehensive social protection systems to protect the most vulnerable populations. 


\section{INTRODUCTION}

1. Burkina Faso's policy implementation has been generally satisfactory. The authorities have maintained the momentum of structural reforms and sound policies that have supported macroeconomic stability and poverty reduction. Continued reform implementation led also to strong performance under IMF-supported programs, and good progress on IMF policy advice following surveillance discussions (Box 1). This performance has helped the authorities secure sustained financial support from the country's development partners.

2. The Executive Board approved a three-year Extended Credit Facility (ECF) arrangement for Burkina Faso on June 14, 2010 with access of SDR 46.15 million (76.67 percent of quota). The Board completed the first and second reviews under the arrangement on December 3, 2010 and July 15, 2011 respectively.

\section{OVERVIEW AND SURVEILLANCE ISSUES}

\section{A. Strong Growth despite a Narrow Productive Base}

3. Economic growth has been sustained and above the average for the WAEMU. The combination of growthenhancing policies and the significant expansion in the mining sector since 2008 has supported economic growth in the last five years. Real GDP growth averaged 5 percent in 2006-10, outperforming other WAEMU countries (Text Figure 1). The impact of exogenous shocks earlier in 2011 was marginal on the main sectors driving growth. Consequently, real GDP is expected to expand by 5.6 percent as anticipated (Table 1, and MEFP \ 2).

\section{Despite generally good growth} performance, the productive base remains narrow. Until the onset of gold production in 2007 , the primary and secondary sectors, dominated by agriculture and ginned cotton, respectively, were the main sources of growth (Text Figure 2). As a result, real GDP growth fluctuated significantly in 2004-10, because of climatic and terms-oftrade shocks.
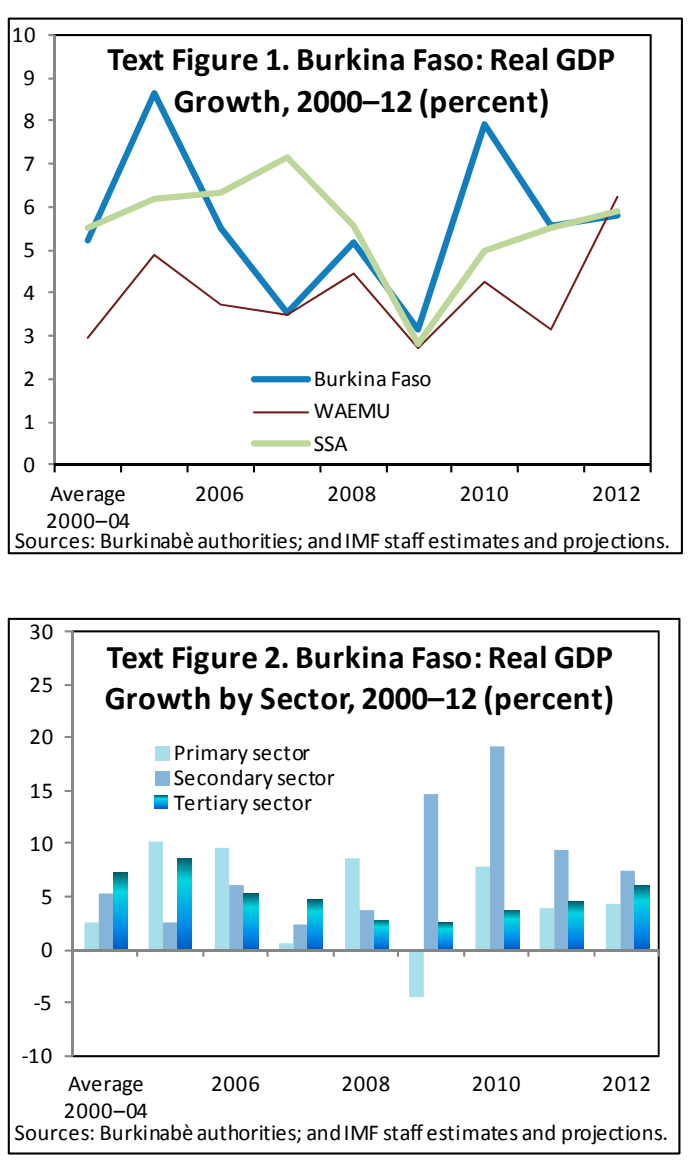
Box 1. Burkina Faso-Status of Policy Recommendations From the 2009 Article IV Consultation

\begin{tabular}{|lll|}
\hline \multicolumn{1}{|c|}{ Policy Area } & $\begin{array}{c}\text { Staff Recommendations During the } \\
\text { 2009 Article IV Consultation }\end{array}$ & \multicolumn{1}{c|}{ Outcome } \\
\hline $\begin{array}{l}\text { Fiscal policy and } \\
\text { public financial } \\
\text { management } \\
\text { (PFM) }\end{array}$ & $\begin{array}{l}\text { Enhance revenue collection through the } \\
\text { implementation of tax reform and } \\
\text { administrative measures. }\end{array}$ & $\begin{array}{l}\text { The authorities prepared a new tax reform strategy with } \\
\text { technical assistance from the IMF and financial support } \\
\text { from Switzerland, and implemented it in 2011. They } \\
\text { also took several revenue-enhancing measures, } \\
\text { including the connection of the majority of customs } \\
\text { offices to the main electronic server. }\end{array}$ \\
& $\begin{array}{ll}\text { Reinvigorate expenditure management } \\
\text { reforms and enhance Treasury cash } \\
\text { flow management. }\end{array}$ & $\begin{array}{l}\text { The authorities streamlined the documentation needed } \\
\text { for expenditure payment and adopted a new treasury } \\
\text { cash flow plan. They also took comprehensive } \\
\text { measures to prepare the transition to a program } \\
\text { budgeting system, and carried out organizational and } \\
\text { financial audits of expenditure commitment systems in } \\
\text { several line ministries. The authorities used the } \\
\text { outcome of the audits to define performance } \\
\text { assessment indicators to reduce delays in expenditure } \\
\text { payment. }\end{array}$ \\
&
\end{tabular}

Cotton sector Continue the rehabilitation of the main cotton ginning company (SOFITEX) and implement cotton sector reforms.

Private sector development

Financial sector

External debt

Petroleum

Products Pricing

System
Implement the financial sector strategy to deepen financial intermediation and broaden access to financial services.

Improve the business environment further and support economic diversification.

Maintain a prudent borrowing policy to safeguard long-term debt sustainability.

Adopt a new pricing and taxation system for petroleum products.
For SOFITEX, key measures included strengthening the company's management based on the results of the 2009 audit; enhancing the information system; recapitalizing the company in accordance with OHADA laws, and preparing a business plan for 201015. The authorities also adopted a new system to finance the cotton price-smoothing fund, in collaboration with other stakeholders.

The authorities set up two commercial courts in the two majors cities; rationalized the employers' tax; and made further progress on some World Bank Doing Business indicators.

The implementation of key measures under the financial sector development strategy has been limited for lack of funding. The authorities prepared a new microfinance development strategy.

The authorities have maintained a prudent borrowing policy, and have enhanced debt management capacity.

The authorities completed a study on a new pricing and taxation mechanism at end-2010. Based on the outcome of the study, they plan to adopt a new pricing system by December 2011. 


\section{B. Inflation Is Moderate}

5. Inflation has remained low. The authorities put in place an incentive program for agriculture production after the 2007 drought. The program has strengthened the supply for agricultural consumer goods, and has helped contain food inflation. After the sharp rise in 2008 driven by the global food and energy crisis, inflation has been trending down, declining to -0.3 percent in 2010. It is expected to inch up in 2011 because of the hike in global oil prices, but would stay below 2 percent (Text Figure 3).

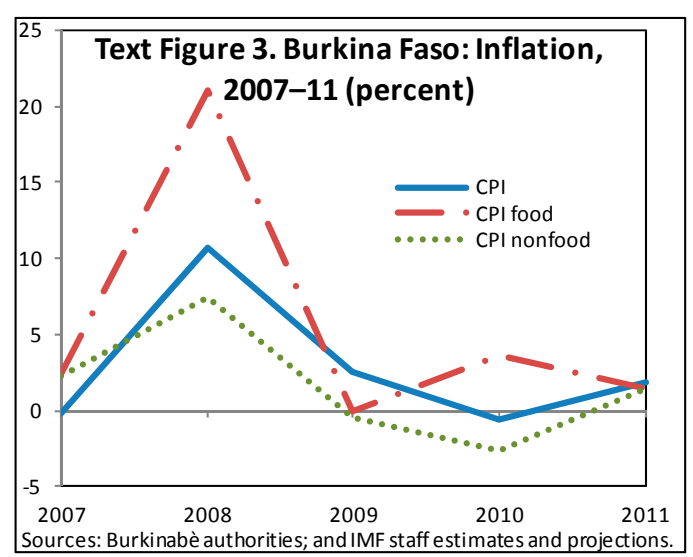

6. The freeze in fuel retail prices has played an important role in containing inflationary pressures. Since the 2008 global energy crisis, the authorities suspended the implementation of the petroleum products price pass-through mechanism, and limited subsidies to sensitive products for consumers and for power generation. This has helped contain the impact of higher global oil prices on inflation, although it caused operating losses for SONABHY.

\section{External Position-Vulnerability to Exogenous Shocks}

7. The external position is structurally fragile. With cotton and gold accounting for 75 percent of exports, and petroleum products representing some 30 percent of imports, Burkina Faso's current account is highly susceptible to exogenous shocks affecting production conditions, particularly for cotton, and to fluctuations in commodity prices. In 2010, the current account deficit narrowed to 71/2 percent of GDP, down from about 9 percent in 2009. Increased export earnings that compensated for the impact of higher oil prices underpinned this improvement. This, however, is expected to be temporary, mostly because of continued strong imports demand, partly reflecting higher oil prices (Text Figures 4 and 5; and Table 2).
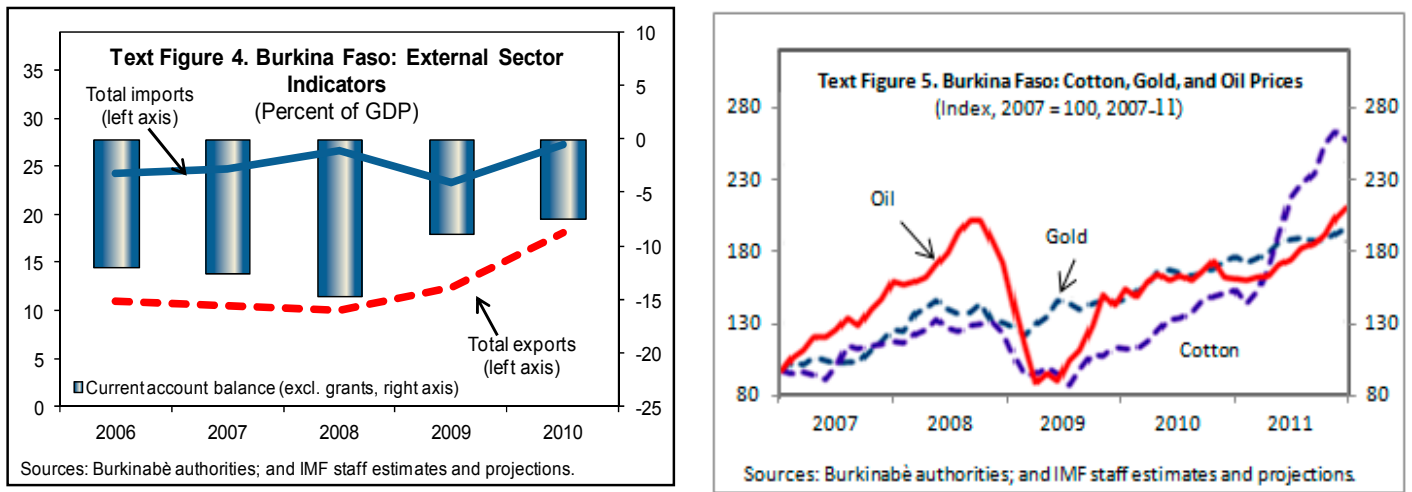


\section{The decline in inflation and the depreciation of the Euro provided some} competitiveness gains in 2010. The real effective exchange rate depreciated by 8.4 percent in 2010 compared with 2009, following years of appreciation (Text Figure 6). Analysis using selected cost indicators also points to an improvement in 2010; and a broader assessment of the REER suggests that it is broadly in line with economic fundamentals (Text Figure 7), consistent with the regional assessment. ${ }^{1}$ Nonetheless, Burkina Faso's performance on non-price competitiveness points to the need for continued improvement in the business climate to support private sector development (Appendix II).
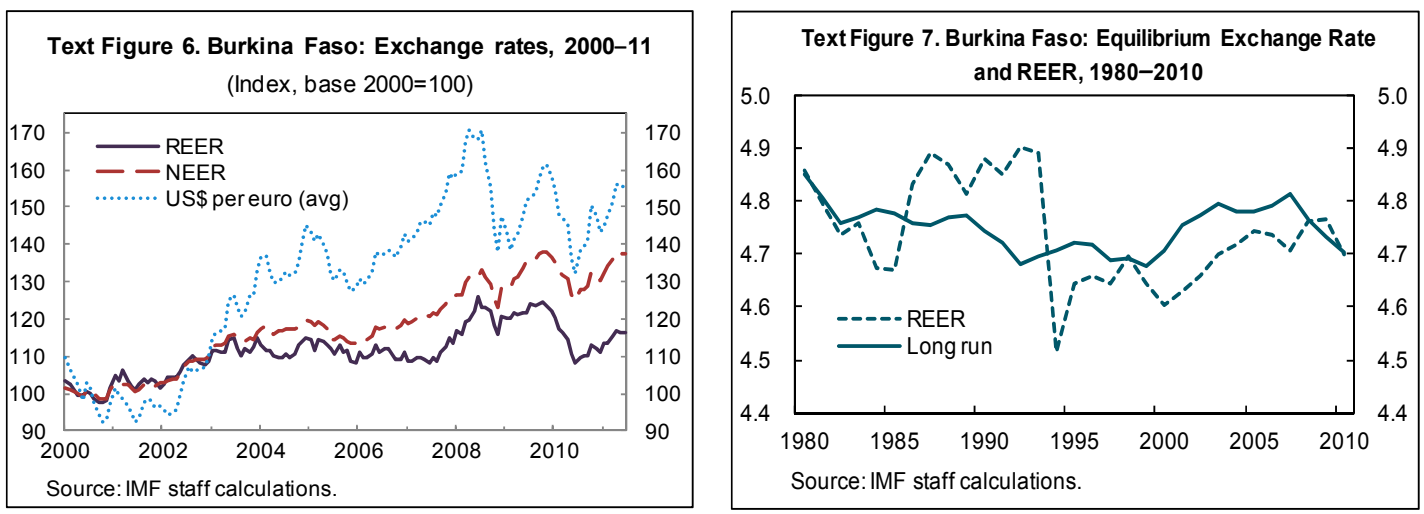

\section{The Financial Sector-Sound with Shallow Financial Intermediation}

9. The financial system is dominated by banks, and financing activities are not diversified. Although the system has expanded in recent years, commercial banks account for the largest share of assets (Box 2). In addition, credit concentration remains high: the financing of cotton production and commercial activities account for the largest share of credit to the economy. The Herfindhal-Hirschmann index shows that credit concentration is moderate, although above the WAEMU average.

10. Vulnerabilities in the financial sector have abated. Progress in the implementation of cotton sector reforms, and other recommendations from the 2008 FSAPreport (Box 3) have lowered vulnerabilities in the sector. In particular, the authorities recapitalized SOFITEX in 2010, and assumed its liabilities to the banking system. In addition, in collaboration with other stakeholders, the authorities set up a new mechanism to contain the impact of price shocks on the financial situation of ginning companies.

\footnotetext{
${ }^{1}$ IMF Country Report No. 11/98 (May 2011).
} 


\section{Box 2. Burkina Faso-Recent Developments in the Financial Sector}

The banking sector has expanded significantly in the last six years. The number of banks increased from 8 in 2005 to 12 in 2011, with their balance sheets growing by 130 percent (figure below). Three banks hold almost 50 percent of the total banking system's assets. Private sector deposits quadrupled, and there has been some diversification and increased access in/to financial services offered by banks. Credit infrastructure improved significantly with the strengthening of both the credit history center and the corporate balance sheet centralization system.

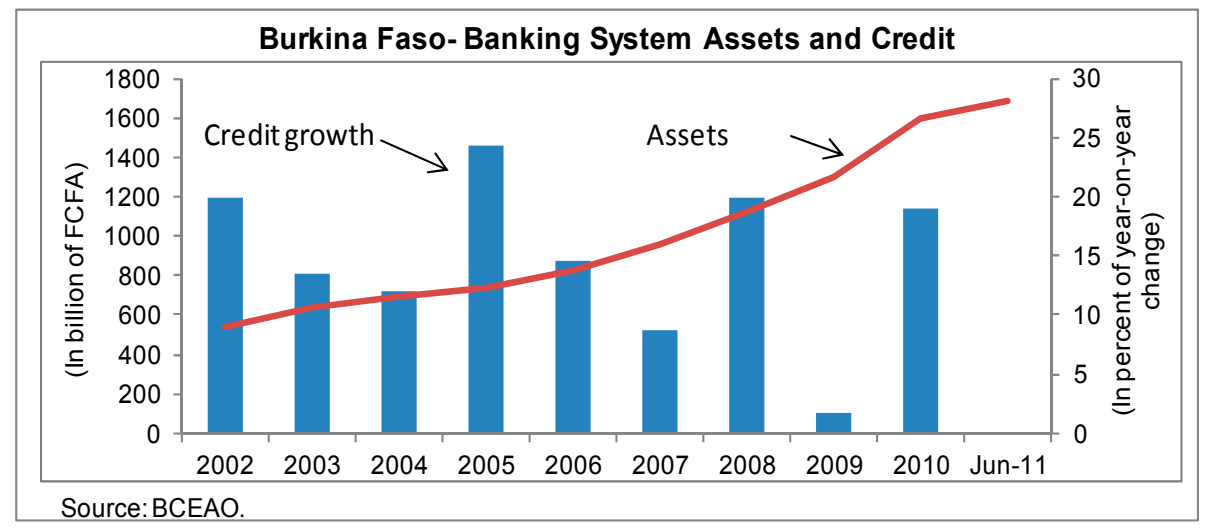

At end-June 2011, the majority of banks met the new regional minimum capital requirement of CFAF 5 billion. Compliance with the regional prudential ratios is generally good (Table below), and non-performing loans remain low. In addition, years of profitability and sound management, as well as weaknesses in the private sector credit market, have put banks in a comfortably liquid position, allowing them to participate actively in the regional bond market, particularly for Treasury bills with 3-to-12 month maturities.

\begin{tabular}{|c|c|c|c|c|c|c|}
\hline \multicolumn{7}{|c|}{ Burkina Faso:Financial Soundness Indicators (2008-2011) } \\
\hline & Jun-08 & Dec-08 & Jun-09 & Dec-09 & Dec-10 & Jun-11 \\
\hline & \multicolumn{6}{|c|}{ (Percent, unless otherwise indicated) } \\
\hline \multicolumn{7}{|l|}{ Capital adequacy } \\
\hline Capital to total assets & 8.0 & 8.3 & 7.7 & 7.4 & 6.5 & 6.5 \\
\hline Regulatory capital to risk-weighted assets & 13.0 & 12.4 & 12.4 & 12.4 & 10.8 & 12.5 \\
\hline Non-performing loans to capital & 49.7 & 34.1 & 47.7 & 32.8 & 35.0 & 47.0 \\
\hline \multicolumn{7}{|l|}{ Asset composition and quality } \\
\hline Total loans to total assets & 62.9 & 59.2 & 47.0 & 54.5 & 52.5 & 57.6 \\
\hline Gross non-performing loans to total loans & 17.9 & 15.8 & 19.4 & 19.7 & 24.0 & 19.7 \\
\hline Provisions to non-performing loans & 64.9 & 66.7 & 77.8 & 70.7 & 60.9 & 63.6 \\
\hline \multicolumn{7}{|l|}{ Earnings and profitability } \\
\hline Noninterest expenses to gross income & 68.0 & 86.1 & 96.3 & 70.4 & 72.0 & 64.0 \\
\hline \multicolumn{7}{|l|}{ Liquidity } \\
\hline Total deposits/Total loans & 94.2 & 93.6 & 98.2 & 106.7 & 82.5 & 82.9 \\
\hline \multicolumn{7}{|l|}{ Compliance levels (number of compliant banks) ${ }^{1}$} \\
\hline Minimum statutory capital & 8 & 9 & 9 & 6 & 10 & 10 \\
\hline Capital adequacy ratio (CAR) & 10 & 11 & 11 & 8 & 10 & 10 \\
\hline Liquidity ratio & 7 & 7 & 8 & 7 & 10 & 7 \\
\hline
\end{tabular}

There are some weaknesses in the regulatory and judicial systems for banks. In particular, debt collection and foreclosure on collateral are inefficient, and the judicial systems remain weak. Although competition has increased in recent years, there is a lack of innovative financial instruments, notably those geared towards small and medium-size enterprises.

The National Social Security Fund (CNSS), the postal service institution (SONAPOST), and microfinance institutions (MFIs) are also key actors in the financial sector. In particular, MFIs have played an increasing role in facilitating access to financial services in rural areas. 
Box 3. Burkina Faso-Progress in Implementation of Key 2008 FSAP Recommendations

Policy Area Recommendations Outcome

Stability of the Strengthen SOFITEX's financial position and risk banking management; improve transparency on SOFITEX's system

operations to help banks better manage risks in financing cotton producers; support the creation of a single bank pool for input financing, and credibly fund mechanisms for dealing with external shocks.

Identify a strategic investor with expertise in financial risks management, to divest from SOFITEX.
Done. Important reforms were implemented in the cotton sector in 2008-10.

Planned for end-2012.

\begin{tabular}{|lll|}
\hline $\begin{array}{l}\text { State exit from } \\
\text { the banks }\end{array}$ & $\begin{array}{l}\text { Identify strategic investors to sell the government's } \\
\text { shares in banks. }\end{array}$ & Done. \\
\hline $\begin{array}{l}\text { Government } \\
\text { cash flow }\end{array}$ & $\begin{array}{l}\text { Improve cash flow forecasts and issue treasury bills } \\
\text { more frequently, as needed. }\end{array}$ & Done. \\
\hline Microfinance & $\begin{array}{l}\text { Transfer to the MFIs professional association the } \\
\text { responsibility for the implementation of the action } \\
\text { plan to strengthen the sector, and strengthen the } \\
\text { supervisory capacity of the Microfinance Directorate. }\end{array}$ & $\begin{array}{l}\text { In progress. The authorities are } \\
\text { finalizing a new strategy for }\end{array}$ \\
& $\begin{array}{l}\text { Promote the enforcement of the OHADA frameworkent. } \\
\text { through increased involvement in regional initiatives. }\end{array}$ & In progress. \\
\hline $\begin{array}{l}\text { Legal and } \\
\text { judicial } \\
\text { framework }\end{array}$ & & \\
& & \\
\end{tabular}




\section{Financial intermediation remains shallow and the maturity mismatch} between deposit and credit structure limits banks' ability to finance the economy. Financial sector development indicators show that comparator countries outpaced Burkina Faso in the last decade (Text Figures 8 and 9; and Text Table 1). Financial intermediation, as measured by the ratio of broad money to GDP is shallow, and credit to the economy remains low, partly because demand deposits are the largest component of banks' resources. For 2011, credit to the economy is expected to increase by 11 percent (Table 3).
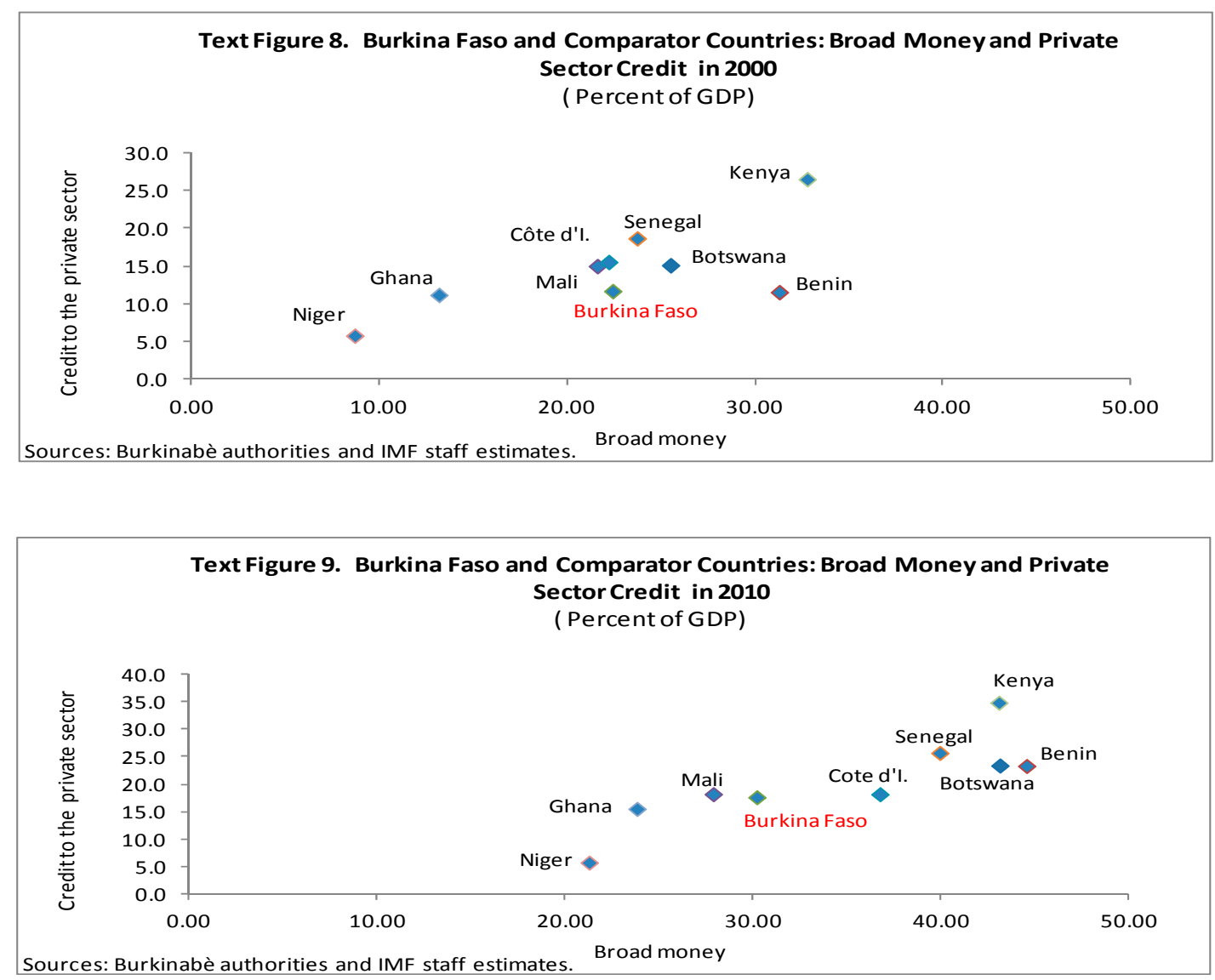

\begin{tabular}{|c|c|c|c|c|c|c|c|c|}
\hline & \multicolumn{8}{|c|}{$\begin{array}{c}\text { Text Table 1. Burkina Faso and Comparator Countries: Selected Financial Sector Indicators } \\
\text { (Percent of GDP unless otherw ise indicated) }\end{array}$} \\
\hline & \multicolumn{2}{|c|}{ M2 } & \multicolumn{2}{|c|}{ Credit to the Private Sector } & \multicolumn{2}{|c|}{ Deposits } & \multicolumn{2}{|c|}{ M1/M2 (percent) } \\
\hline & 2000 & 2010 & 2000 & 2010 & 2000 & 2010 & 2000 & 2010 \\
\hline Burkina Faso & 22.4 & 30.2 & 11.7 & 17.6 & 14.7 & 25.3 & 63.9 & 50.0 \\
\hline Botsw ana & 25.5 & 43.1 & 15.1 & 23.4 & 24.0 & 41.2 & 25.9 & 22.8 \\
\hline Benin & 31.3 & 44.6 & 11.6 & 23.3 & 18.7 & 33.9 & 98.8 & 99.4 \\
\hline Mali & 21.6 & 27.9 & 15.0 & 18.2 & 13.8 & 21.1 & 36.3 & 24.3 \\
\hline Côte d'Ivoire & 22.2 & 36.8 & 15.5 & 18.2 & 13.8 & 22.3 & 99.8 & 99.8 \\
\hline Senegal & 23.7 & 39.9 & 18.7 & 25.7 & 18.6 & 31.1 & 58.8 & 61.0 \\
\hline Ghana & 13.2 & 23.8 & 11.2 & 15.5 & 6.6 & 17.5 & 65.7 & 58.4 \\
\hline Niger & 8.7 & 21.3 & 5.8 & 12.8 & 6.0 & 12.6 & 73.8 & 78.5 \\
\hline Kenya & 32.8 & 43.1 & 26.5 & 34.8 & N/A & 44.6 & 37.9 & 52.5 \\
\hline Nigeria & 20.8 & 33.9 & 12.2 & 30.0 & 15.0 & 30.2 & 63.3 & 55.2 \\
\hline
\end{tabular}




\section{E. Fiscal Policy-Sustained Consolidation Efforts}

12. The authorities have generally maintained fiscal discipline. They have sustained revenue mobilization efforts and overall expenditure restraint, while addressing the impact of exogenous shocks. Revenue collection has benefitted from continued efforts to improve tax administration and combat fraud, tax reform measures, and increased revenue from the mining sector (Box 4). Tax revenue increased from 11.7 percent of GDP in 2005 to 13.0 percent in 2010 (MEFP 996 6). The strong revenue performance and high external budget support helped the authorities increase domestically financed investment and pro-poor spending, and address exceptional needs triggered by adverse shocks in 2009-11. ${ }^{2}$ Expenditure rose from 22.3 percent of GDP in 2005 to 25.7 percent in 2010, with an increasing share of capital expenditure. This notwithstanding, the overall budget deficit (including grants) rose from 5 percent of GDP in 2005 to 5.6 percent in 2010 (Table 4).

\section{MEDIUM-TERM OUTLOOK}

\section{Medium-term macroeconomic} prospects are promising. Economic growth is expected to remain strong, mostly driven by agriculture, cotton, mining, and services sectors, as well as higher public investment (Text Figure 10). In agriculture, production would benefit from continued implementation of measures aimed at supporting higher productivity and agricultural food supply. Regarding cotton, improvement in the global market conditions,

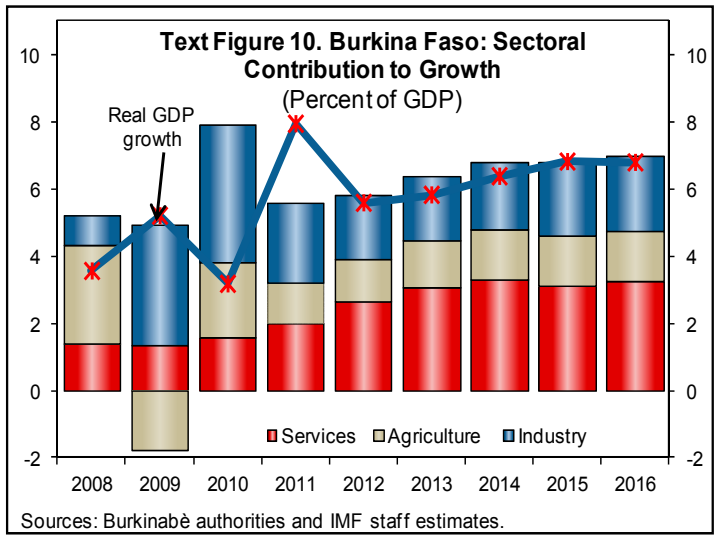
and higher productivity, thanks to the extended use of genetically modified seeds should boost production in 2012-16. Valueadded in the mining sector is set to benefit from the projected increase in gold and manganese activities. Inflation should remain moderate, consistent with the WAEMU regional convergence criterion.

\section{The external position would deteriorate in the medium-term} (Text Figure 11). The current account deficit

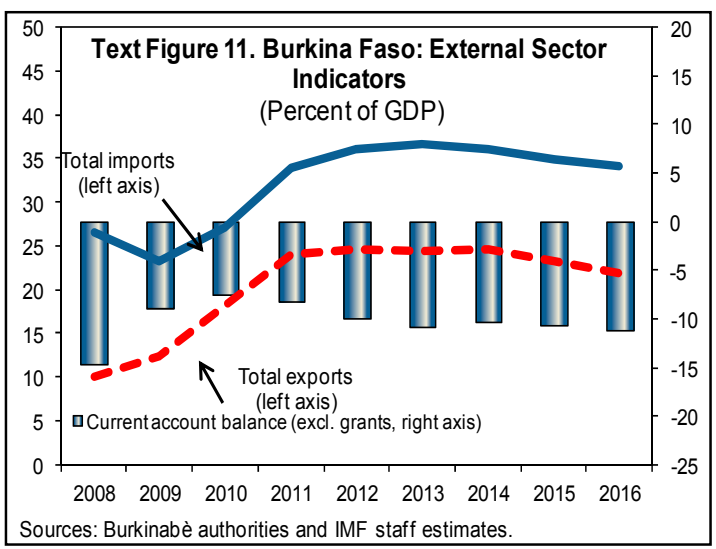
is forecast at 11.2 percent of GDP in 2016, up from 8.2 percent in 2011, mainly because

\footnotetext{
${ }^{2}$ In 2009-11, exceptional spending was triggered by heavy floods (2009); the impact of the global economic slowdown, particularly in the cotton sector (2010); spillover effects from the crisis in Côte d'Ivoire (through February 2011); and the impact of social unrest (February-June 2011).
} 


\section{Box 4. Burkina Faso-Mining Sector Developments}

Production. The mining sector has expanded significantly since 2007. Production has surged from $362 \mathrm{~kg}$ in 2007 to 31 tons in 2011, with the number of mines growing tenfold. Overall, Burkina Faso is a marginal gold producer in Africa (chart below). Since 2009, the four largest mines account for about two thirds of the formal production. The sector's contribution to GDP has also risen tenfold in 2008-10.

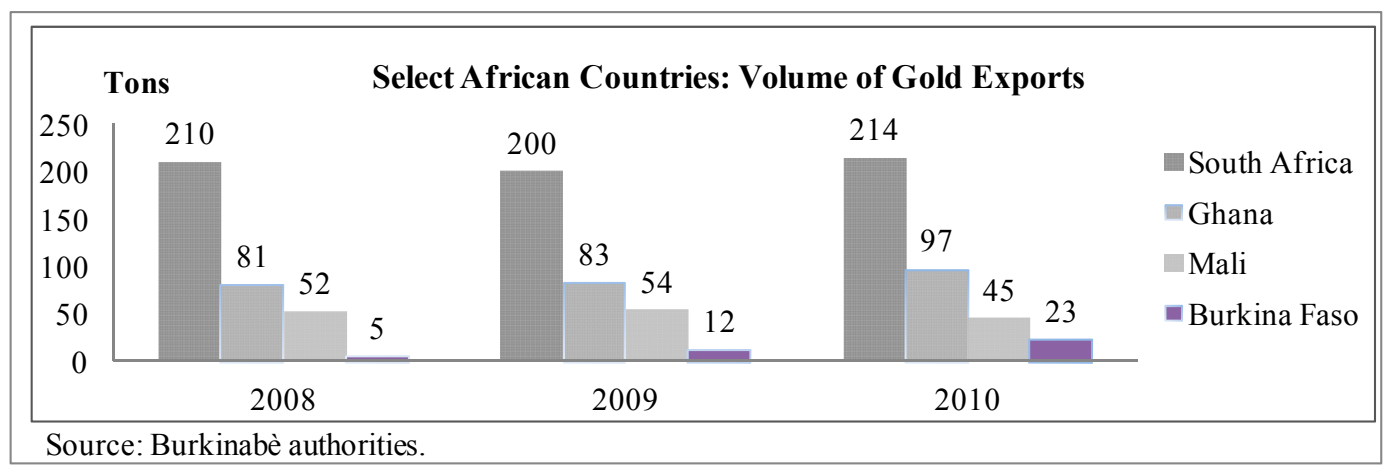

Export. Gold has overtaken cotton as the main export for Burkina Faso. While cotton export grew by 25 percent in 2008-11, gold export has increased tenfold during the same period, reflecting both strong global prices and increased production. At current gold prices, mining companies are expected to sustain production and increase investment in new mines.

Taxation. Revenue from the mining sector covers mainly royalties and corporate income taxes. With the expansion in the sector's activity, revenue increased from about $1 / 2$ percent of GDP in 2009 to about 1 percent in 2010, and a projected 1.8 percent in 2011 (text table below). In 2010, revenue from the mining sector accounted for about 7 percent of total government revenue. Since 2010, the royalty rate moved from a single 3 percent rate to a sliding scale system of 3-5 percent depending on global prices (US\$1,500/ounce is the trigger level for the higher rate, and US $\$ 1,300$ /ounce is the floor price for the lower rate). Mining companies pay corporate income tax at a reduced rate during the 3 -year tax holiday period. The State holds a 10 percent stake in mining companies. There has not been a distribution of dividends so far.

\begin{tabular}{|lrrr|}
\hline \multicolumn{4}{|c|}{ Revenue from the Mining Sec tor (CFAF billions) } \\
\hline & 2009 & 2010 & $2011^{1}$ \\
\hline Tax revenue & 5.9 & 24.2 & 54.6 \\
Customs revenue & 4.2 & 9.1 & 9.0 \\
Nontax revenue (including royalties) & 5.6 & 12.0 & 21.1 \\
Total revenue & $\mathbf{1 5 . 7}$ & $\mathbf{4 6 . 3}$ & $\mathbf{8 4 . 6}$ \\
\hline So urce: Burkinabè authorities. & \multicolumn{2}{c}{ At end August 2011. } \\
\hline
\end{tabular}

Transparency. Burkina Faso has accompanied the development of the mining industry with a strong effort to adhere to the Extractive Industries Transparency Initiative (EITI). It has been a candidate country since 2008, and has undertaken activities in three areas: capacity building, information dissemination, and reporting.

Burkina Faso's full membership in the EITI required a judgment of conformity with 22 criteria by May 2011. However, a six-month extension for the final assessment was granted because of the unrest of early 2011 . The first reconciliation report was published in March 2011. 
Burkina Faso's terms of trade are not expected to improve over the medium term. Exports are projected to decelerate somewhat, while imports demand would remain firm, in line with higher economic growth and investment.

15. The balance of risks is on the downside, and mainly related to the economy's vulnerability to exogenous shocks. Should these risks materialize, they would jeopardize economic growth and may generate additional spending, thus hampering fiscal consolidation.

- $\quad$ A global economic downturn with lower demand and commodity prices would adversely affect the cotton sector, as was the case in 2008-09. Its impact on the external current account would depend on developments in global oil and gold prices.

- An adverse change in climatic conditions that would affect the agriculture and cotton sectors is an important downside risk for growth and the balance of payments outlook.

\section{Policy Discussions}

16. Considering medium-term objectives and challenges, policy discussions focused on four areas:

- $\quad$ Supporting fiscal sustainability.

- $\quad$ Strengthening debt policy and management capacity.

- $\quad$ Enhancing growth prospects and;

- Improving social policies.

\section{A. Supporting Fiscal Sustainability}

17. The authorities agreed with staff that meeting the medium-term program objectives would require continued fiscal consolidation. They plan to enhance revenue mobilization in a medium-term fiscal strategy under preparation, and to continue strengthening expenditure management (Text Figure 12). Staff urged the authorities to increase public savings, to rebuild treasury deposits and strengthen

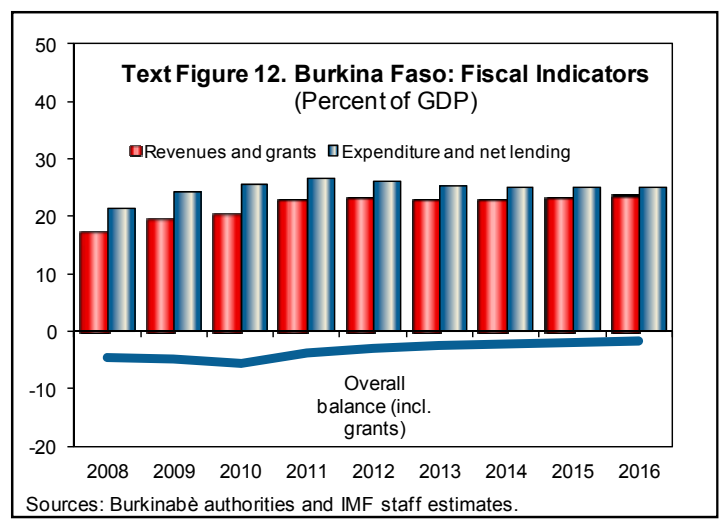
their ability to address unforeseen exogenous shocks, particularly for vulnerable groups.

18. The medium-term fiscal program assumes that revenue would increase from 15.8 percent of GDP in 2011 to 17.4 percent in 2016, supported by: (i) higher tax 
revenue consistent with the projected economic growth, and higher imports;

(ii) additional administrative efficiency gains and; (iii) increased revenue from the mining sector, reflecting expiring tax holidays, strong gold prices, and sustained production. As mining revenue rises, the authorities would have to ensure that, medium-term expenditure frameworks shield the budget from volatility in global gold prices, and account for the exhaustible nature of mining revenue.

19. After the implementation of one-off social measures in 2011 , expenditure would decline from 26.7 percent of GDP in 2011 to 25.1 percent in 2016. Nonetheless, propoor spending will rise by 10 percent, and capital outlays would increase from 12.4 percent of GDP in 2011 to 13.2 percent in 2016 (Text Figure 13). The increase in public investment would

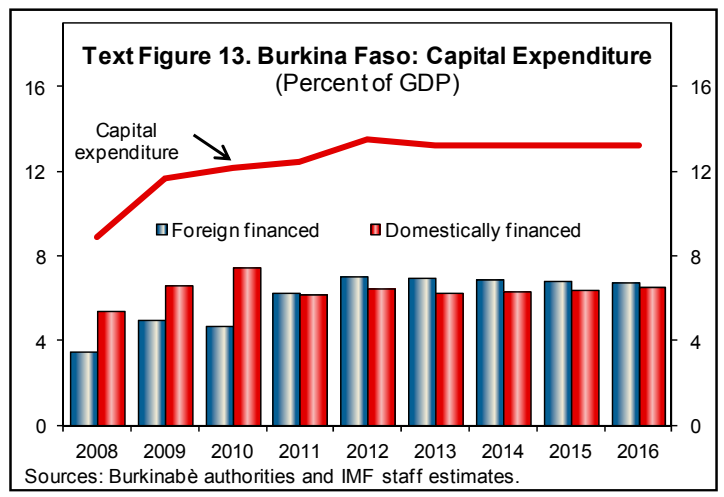
cover rehabilitation of roads and dams, including those damaged by the 2009 floods, new infrastructure projects; and planned large investment projects, notably the Samendeni dam, the Donsin airport, and the Bagré growth pole. The authorities plan to consider private sector participation in these projects, under the Public Private Partnerships legislation. During the discussions, the authorities agreed with staff on the importance of addressing absorptive capacity constraints, and ensuring that selected investment projects are consistent with PRSP objectives. They also concurred that financing options for the scaled-up investment had to be consistent with the long-term debt sustainability objective.

20. The overall budget deficit is projected to decline from 3.0 percent of GDP in 2012 to 1.8 percent in 2016 . It would be mostly financed with budget grants projected to average some 2.7 percent of GDP.

\section{B. Strengthening Debt Policy and Management Capacity}

\section{The risk of debt distress remains high and debt policy should remain}

prudent. Results from the DSA indicate that under current policies, the present value of debt-to-exports ratio would breach its indicative threshold around 2026 in the baseline scenario and under stress tests (Figure 1). The authorities agreed with staff that these results highlight Burkina Faso's narrow export base and the need to maintain a prudent borrowing policy, relying mostly on grants and highly concessional loans. Nonetheless, they insisted that flexibility in borrowing conditions under the current IMF/World Bank Debt Limits Framework would help Burkina Faso broaden financing sources for the investment scaling-up envisioned in the PRSP.

\section{Staff called the authorities' attention on results from the application of a} Dynamic General Equilibrium (DGE) model linking investment, economic growth and debt sustainability on Burkina Faso (Appendix III): 
- Simulation results from the application of a DGE model show that, under certain conditions, scaling-up investment to levels envisioned in the authorities' new PRSP would raise economic growth substantially in the medium to long term, boost private investment, and increase consumption. They also indicate that financing options for the scaled-up investment should be selected based on their implications for long-term fiscal and debt sustainability. In particular, simulation results show that financing the scaled-up investment through higher concessional borrowing, or access to commercial loans, would lead to unsustainable levels of external debt.

- Taking into account Burkina Faso's particular circumstances, notably the membership to a customs and monetary union, the high risk of debt distress under the 2011 DSA, and the economy's vulnerability to exogenous shocks, simulation results seem to indicate that a better macroeconomic outcome would be achieved through moderate and sustained increase in public investment, financed through higher grants and concessional loans, as well as increased government revenue.

\section{The authorities welcomed the analysis and broadly agreed with the policy}

recommendations. They found that the financing option with higher grants and concessional loans was consistent with their approach for financing the scaled-up investment envisaged in their new PRSP. In this vein, they expressed interest in using the model's results for the upcoming donors' conference scheduled for early 2012. In the discussion, the authorities found that under all simulation scenarios, the tax adjustment was neither realistic nor feasible because of Burkina Faso's obligations on VAT harmonization as a member of a monetary and customs union. Nonetheless, they concurred with staff on the need to continue enhancing revenue mobilization.

\section{The authorities agreed with staff that debt management capacity needs}

further improvement (MEFP 124 ). In recent years, the authorities have taken measures to strengthen debt management capacity by preparing a procedure manual, strengthening the treasury cash flow management, and setting-up an integrated system to monitor external financing. The 2011 World Bank DeMPA report concluded that most debt management indicators had improved compared to the 2008 assessment, although some weaknesses remain, particularly regarding debt management strategy. Staff encouraged the authorities to seek technical assistance for the preparation of a well-articulated medium-term debt management strategy in 2012, to further their debt management capacity. 


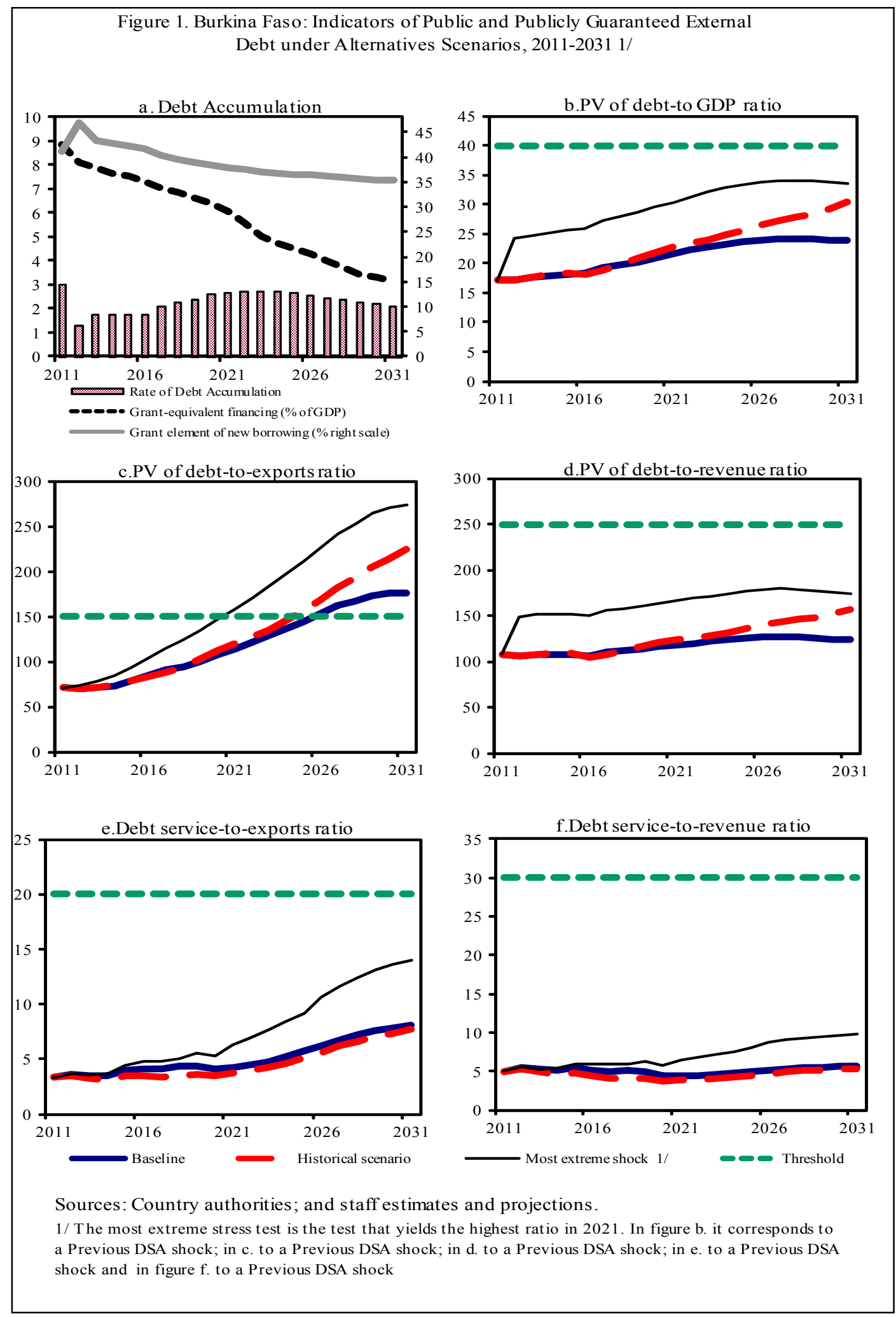

CInternational Monetary Fund. Not for Redistribution 


\section{Enhancing Growth Prospects}

25. The authorities reaffirmed their commitment to growth-enhancing policies to reach PRSP objectives. They have given priority to scaling up public investment, notably in infrastructure; supporting productivity gains in agriculture; and enhancing diversification in agriculture, mining, and agribusiness. Structural conditionality under the ECF-supported program seeks to support the authorities' objectives for macroeconomic stability and growth.

\section{Staff emphasized that continued efforts to improve the business environment} are needed to support private sector led-growth. Measures taken in recent years to improve the business climate have helped Burkina Faso's ranking on the World Bank Doing Business indicators (Figure 2). However, the authorities need to consolidate recent progress with judicial reforms, as well as measures aimed at supporting productivity gains in the private sector and reducing transactions costs. Staff argued that measures planned for 2011-12 to increase efficiency and transparency in merchandise customs clearance and in the public procurement system will play an important role in reducing transaction costs for the private sector. Similarly, higher investment in infrastructure, and increased power supply planned by the authorities and SONABEL for 2012, and in the mediumterm would support private sector development and enhance growth prospects.

\section{The authorities agreed with staff that continued progress in structural} reforms is essential to accelerating growth. They concurred that it was urgent to accelerate the implementation of financial sector reforms to broaden access to financial services, particularly for small and medium-sized enterprises. Staff urged them avoid any delays in the implementation of the microfinance development strategy, and to progress with the preparation of the SONAPOST strategy to enhance the quality of postal financial services. Staff reiterated that recent progress and improved global prospects in the cotton sector provided a good opportunity to accelerate reforms aimed at putting ginning companies on a solid footing. The authorities are preparing a strategy for the gradual reduction of the State's stake in SOFITEX for 2012 (MEFP qף 26-30).

\section{Improving Social Policies}

28. Social indicators remain weak despite recent improvements. The incidence of poverty is estimated to have increased, particularly in urban areas, partly reflecting the impact of adverse shocks in 2007-2010 that affected vulnerable groups. According to World Bank estimates, the incidence of poverty rose from 42 percent in 2006 to 44 percent in 2009. In addition, Burkina Faso's UN Human Development Indicator is 0.31 , the ninth lowest in the World, making poverty reduction an important priority and challenge for the authorities. Pro-poor spending rose from 17.5 percent of total expenditure in 2001 to 28 percent in 2010 (Table 7).

29. Progress towards the MDGs has been uneven. Burkina Faso is unlikely to meet the MDGs. Nonetheless, the country has made progress in some indicators: (i) access to safe drinking water; (ii) primary school net enrollment rate; (iii) reduction in maternal 
mortality; (iv) the ratio of girls to boys in primary education and; (v) access to antiretroviral drugs for the population with advanced HIV/AIDS (Figure 3 and Table 8).

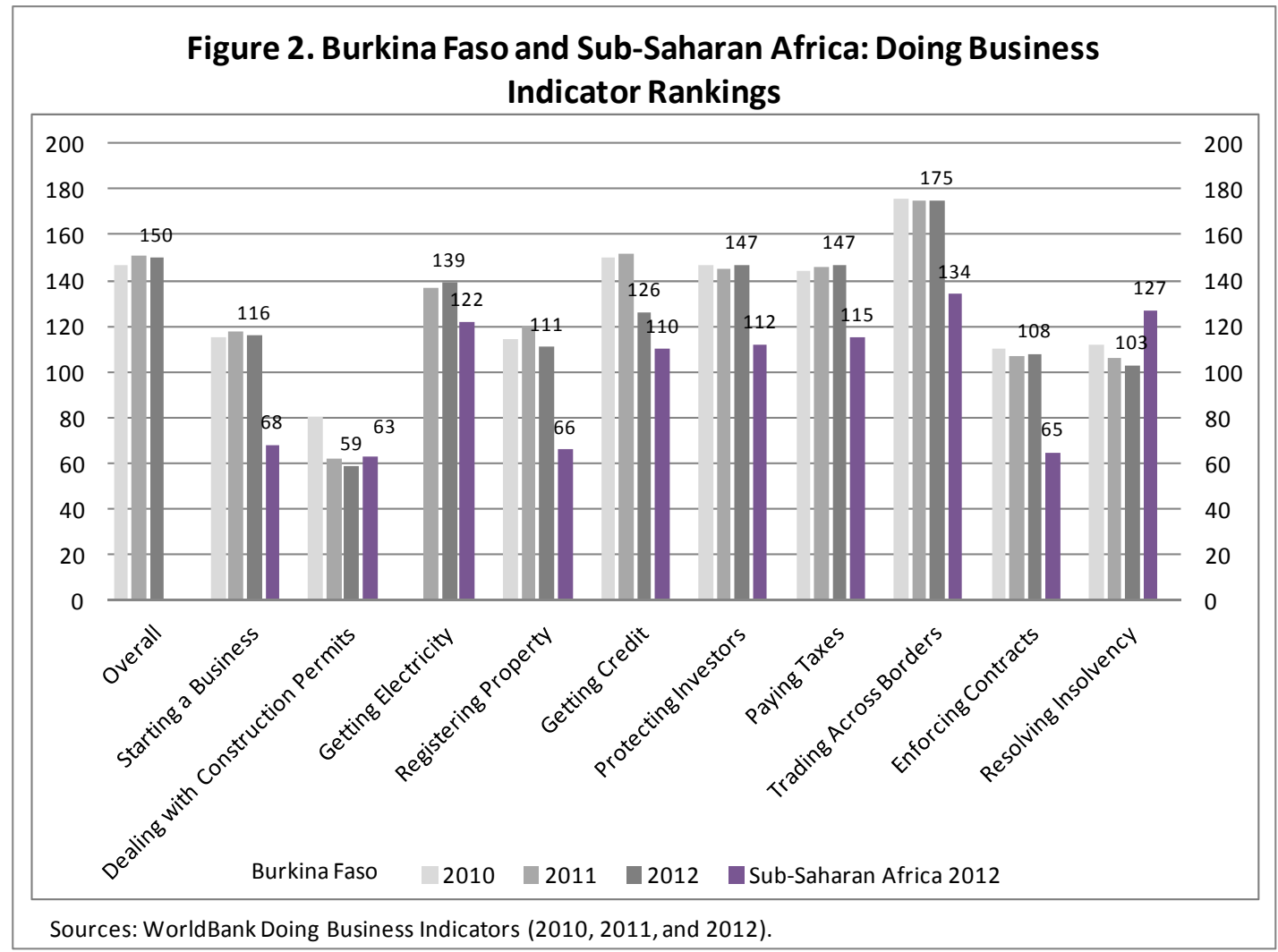

30. In line with the PRSP, the authorities plan to intensify poverty reduction measures and prepare social protection systems. For 2012, they intend to give priority to measures aimed at reducing hardship and enhancing employment opportunities for vulnerable groups (MEFP, ๆ 25). 
Figure 3. Burkina Faso: Selected Millennium Development Goals Indicators

Burkina Faso has already reached the objective for some indicators...
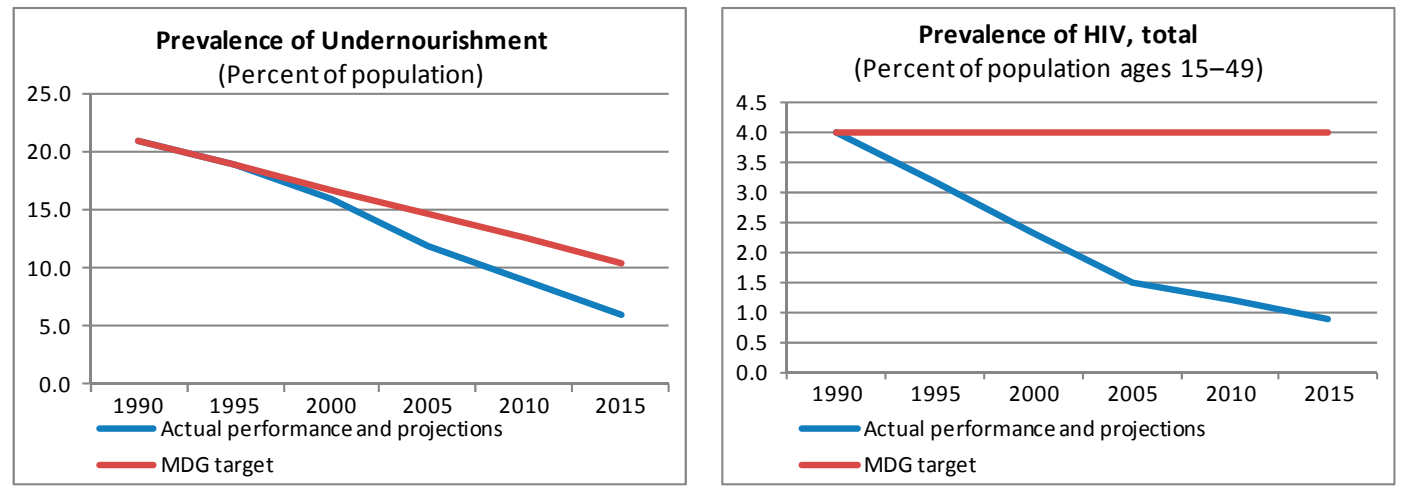

while significant progress is needed for other key indicators...
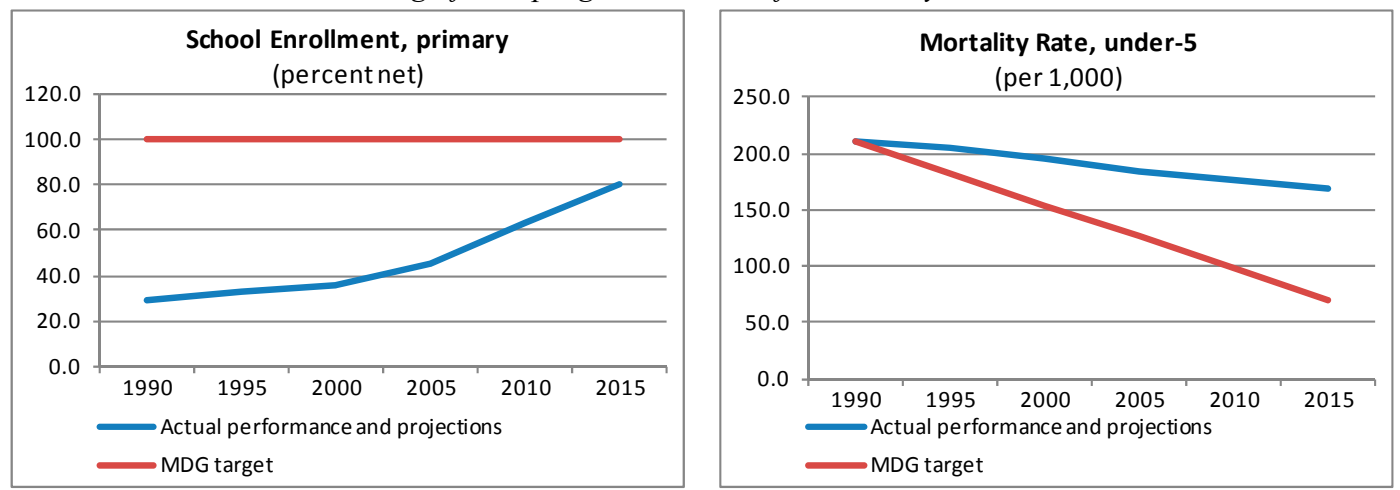

in health and education.
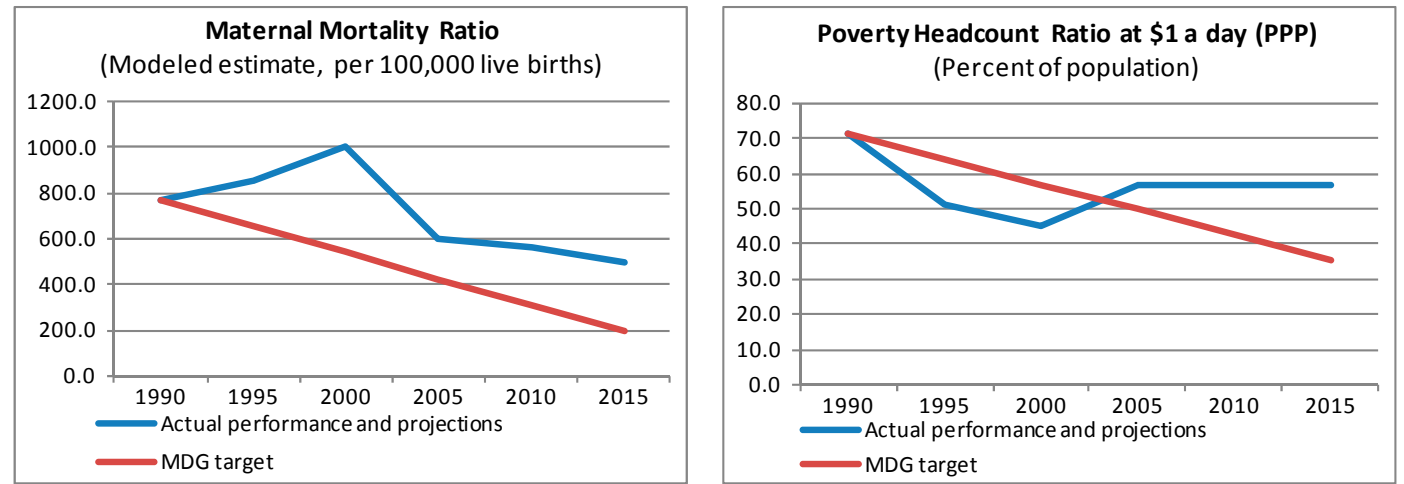

Sources: World Development Indicators 2011 and IMF staff projections. 


\section{Program Performance and Policy for the Rest of 2011-12}

\section{Performance under the program has been good despite the impact of social} turmoil in the first part of the year. At end-June 2011, all quantitative performance criteria, and indicative targets, but one, were met (Text Table 2). The performance criterion on the overall budget deficit (including grants), was met with a wide margin, after adjustment for the shortfall in grants at end-June. The indicative target on revenue was exceeded mainly because of a stronger-than-anticipated revenue from the corporate sector following the implementation of the 2010 tax reform. However, poverty-reducing social expenditure was below target, reflecting delays in budget execution, partly linked to the social turmoil in early 2011.

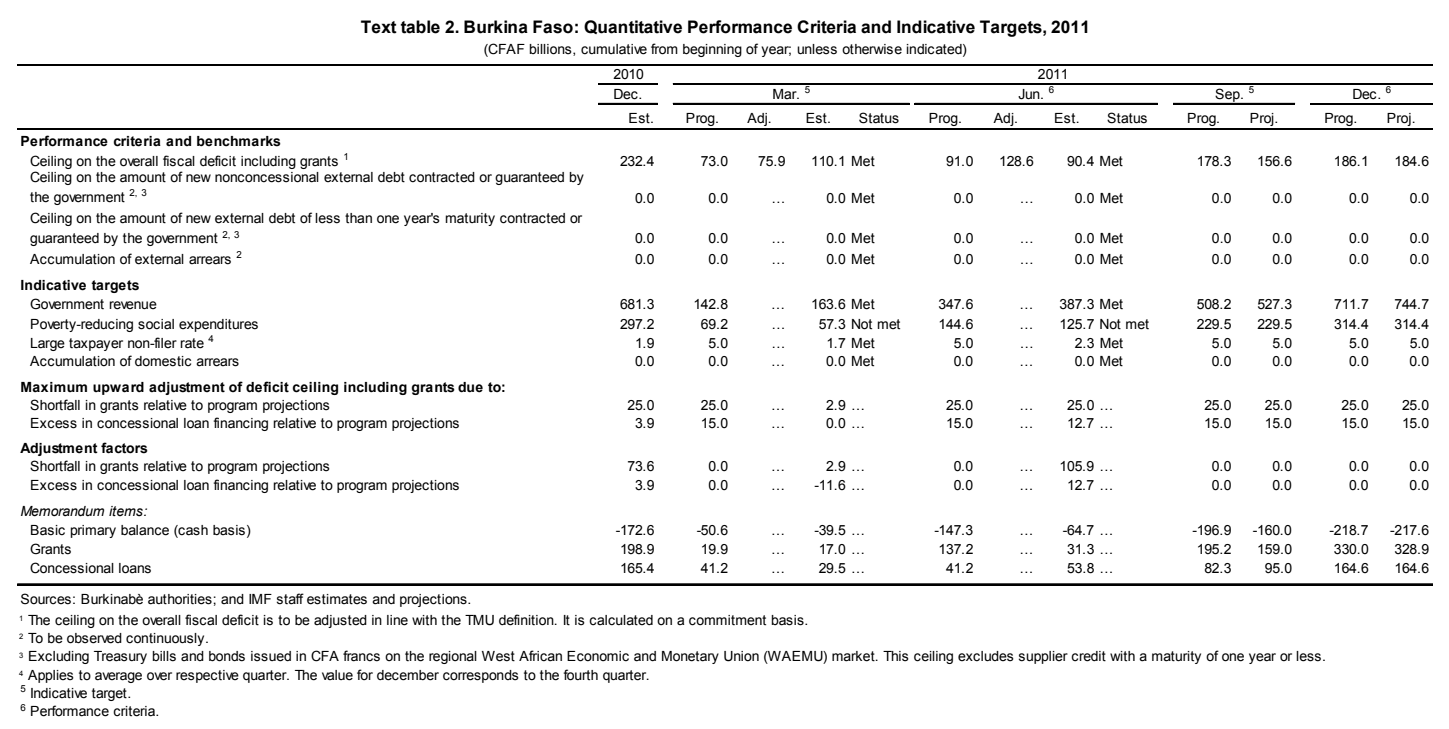

32. The authorities implemented most structural measures for the third review

(Text Table 3). An audit of the expenditure commitment systems in line ministries was completed, and a new system integrating external financing flows was put in place as expected. In the cotton sector, the study on new financing mechanisms for the pricesmoothing fund was completed. The study's recommendations provided a basis for setting the producer prices and bonuses for the 2011-12 crop. However, the second study on the cotton inputs fund was completed with a two-month delay.

\section{The authorities recognized the need to maintain a prudent fiscal policy to} meet the programmed fiscal targets. In the 2011 supplementary budget, the basic primary balance is projected to narrow to 4.2 percent of GDP (5 percent in 2010), as anticipated at the time of the second review. Revenue mobilization is set to benefit from a stronger than anticipated impact of the 2010 tax reform, and higher revenue from the mining sector because of the end of the tax holiday for some mining companies, and higher royalties (MEFP $\$ 19$ ). Expenditure would be slightly above the original program level, because some capital expenditure from the 2010 investment program was executed in early 2011. Current expenditure is expected to be on target, with the wage bill slightly above the programmed level, reflecting the authorities' decision to increase some civil 
servants' benefits in the fourth quarter. The adjustment is part of a broader set of measures, some of which were implemented in May 2011, ${ }^{3}$ aimed at addressing demands from labor unions in the aftermath of the 2011 social unrest. The authorities have taken steps to accelerate the execution of the investment program in the second half of the year, to ensure that capital outlays are consistent with original projections.

Text Table 3. Structural Benchmarks, January-June 2011

\begin{tabular}{|c|c|c|}
\hline Measures & Target Date & Status \\
\hline \multicolumn{3}{|l|}{ Public Financial Management } \\
\hline $\begin{array}{l}\text { Prepare an audit of expenditure commitment systems in } \\
\text { line ministries. }\end{array}$ & $\begin{array}{l}\text { End-June } 2011 \\
\text { (Third review) }\end{array}$ & Done. \\
\hline $\begin{array}{l}\text { Implementation of the integrated circuit for external } \\
\text { financing. }\end{array}$ & $\begin{array}{l}\text { End-June. } 2011 \\
\text { (Third review) }\end{array}$ & Done. \\
\hline \multicolumn{3}{|l|}{ Cotton Sector } \\
\hline $\begin{array}{l}\text { Adopt the recommendations of the studies on financing } \\
\text { mechanisms for the price-smoothing fund, and for the input } \\
\text { fund, and develop an action plan for implementing the new } \\
\text { mechanisms. }\end{array}$ & $\begin{array}{l}\text { End-June } 2011 \\
\text { (Third review) }\end{array}$ & Partially met ${ }^{1}$ \\
\hline \multicolumn{3}{|l|}{ Financial Sector } \\
\hline Implement the microfinance strategy. & $\begin{array}{l}\text { End-June } 2011 \\
\text { (Third review) }\end{array}$ & $\begin{array}{l}\text { Delayed to end- } \\
\text { December } 2011\end{array}$ \\
\hline
\end{tabular}

34. The 2012 fiscal program is consistent with the medium-term fiscal objectives. The basic primary balance is projected at 2.5 percent of GDP, down from 4.2 percent in 2011 (Table 4). To raise revenue to 16.2 percent of GDP, the authorities plan to intensify efforts to reduce tax evasion and fraud, enhance transit trade monitoring, and increase information technology resources in revenue collecting agencies. To this end, the authorities plan to set up a one-stop window for customs clearance, and an electronic system to improve merchandise valuation in two customs posts. Expenditure composition reflects the authorities' resolve to increase capital expenditure to support growth objectives. It also takes into account wage adjustments budgeted for 2012, covering the elimination of overdue payments on past promotions for some civil servants, an increase is some benefits to reduce inequities in the compensation system; and a 5 percent salary increase. These measures would raise the wage bill to 6.3 percent of GDP, up from 6 percent in 2011(MEFP, 9 ๆ 18-22).

35. Staff emphasized that civil service reforms were critical for the attainment of fiscal objectives. It encouraged the authorities to maintain the merit-based promotion

\footnotetext{
${ }^{3}$ See IMF Country Report No. 11/226.
} 
system, while taking the necessary administrative measures to ensure that promotions in the civil service are paid within the year. Key reform measures programmed for 2012 include completing the civil service census, setting-up biometrics cards for civil servants, and completing a diagnostic study on the compensation system. The authorities are hopeful that these measures will generate some savings and contribute to lowering the wage bill as a share of GDP over the medium term.

36. The program is fully financed. At 9.9 percent of GDP, the overall budget deficit on a cash basis, would be covered with external financing and borrowing from the WAEMU bond market.

37. The attached Letter of Intent updates the government's policies and commitments for 2011-12. The authorities reaffirmed their commitment to policies geared towards macroeconomic stability and growth-enhancing structural reforms. The focus remains on furthering reforms in PFM, civil service, and cotton and financial sectors reforms. They are requesting that the implementation of the microfinance strategy, not observed at end-June because of technical problems, be rescheduled to end-December 2011. Understandings were reached on a new structural benchmark for December 2012 for reviewing the compensation system and making the harmonized personnel management system operational. This should strengthen the wage policy and reduce inequities in the civil service payroll.

38. The program will be monitored on a semiannual basis. Staff agreed with the authorities on quantitative benchmarks and performance criteria as well as structural benchmarks for the fourth and fifth ECF reviews. Quantitative financial targets for endJune and end-December 2012 are performance criteria (Appendix I). The fourth and fifth ECF reviews are expected to be completed by June 15, and December 15, 2012 respectively.

39. Burkina's capacity to repay the Fund is sound. Debt service to the Fund is projected at SDR 5.0 million at the end-2012, or 0.3 percent of exports of goods and services, and 8.3 percent of quota (Table 5).

\section{Staff Appraisal}

40. Economic developments and prospects are promising. Despite exogenous shocks in 2011, performance in agriculture, cotton, mining, and services sectors is expected to be strong and support the projected growth for 2011-12. Price pressures earlier in the year have subsided, and inflation should remain moderate. The outlook is, however, subject to downside risks linked to a potential worsening of the global economy, and climatic conditions.

41. Decisive structural reforms are needed to support the authorities' objectives in the PRSP. Although economic growth has generally been strong, the narrow production base is an important source of vulnerability for the economy. To support growth and poverty reduction objectives in the PRSP, it will be critical to accelerate growth-enhancing structural reforms, particularly in the cotton and financial sectors; and to improve the business climate further. Staff encourages the authorities to proceed with 
the implementation of diversification and other growth supporting initiatives envisioned in the PRSP.

42. Staff finds that fiscal policy is focus appropriately on enhancing revenue mobilization and creating adequate space for priority spending and investment. Sustained implementation of revenue-enhancing measures, combine with high levels of budget aid, supported the authorities' efforts to increase social spending, address exceptional needs triggered by exogenous shocks and social unrest, and increase domestically financed investment. Staff urges the authorities to maintain revenue mobilization efforts, and to prepare a medium-term revenue strategy to underpin their objectives under the PRSP. Staff believes that a strong revenue performance would also shield the budget from potential fluctuations in external budget support, and price shocks. More generally, staff encourages the authorities to maintain fiscal discipline, enhance expenditure management further, and improve efficiency in public investment execution to support economic growth, and long-term debt sustainability.

43. Staff commends the authorities for maintaining sound policies under the program despite a difficult environment in the first half of 2012. All quantitative performance criteria and indicative targets for end-June 2011 were met, except for poverty-reducing spending and; most structural benchmarks were observed. Staff urges the authorities to meet the annual targets for pro-poor spending, particularly in light of the impact of adverse shocks on vulnerable groups earlier in 2011.

\section{Staff supports the authorities' request for the completion of the third ECF}

review. Based on a strong program performance and the authorities' policy commitment in the Letter of Intent, staff supports their request for completion of the third review and the disbursement of the fourth loan under the ECF arrangement.

45. It is proposed that the next Article IV consultation with Burkina Faso takes place in accordance with Decision No. 14747 (10/96) adopted on September 28, 2010, on consultation cycles. 
Table 1. Burkina Faso: Selected Economic and Financial Indicators, 2008-16

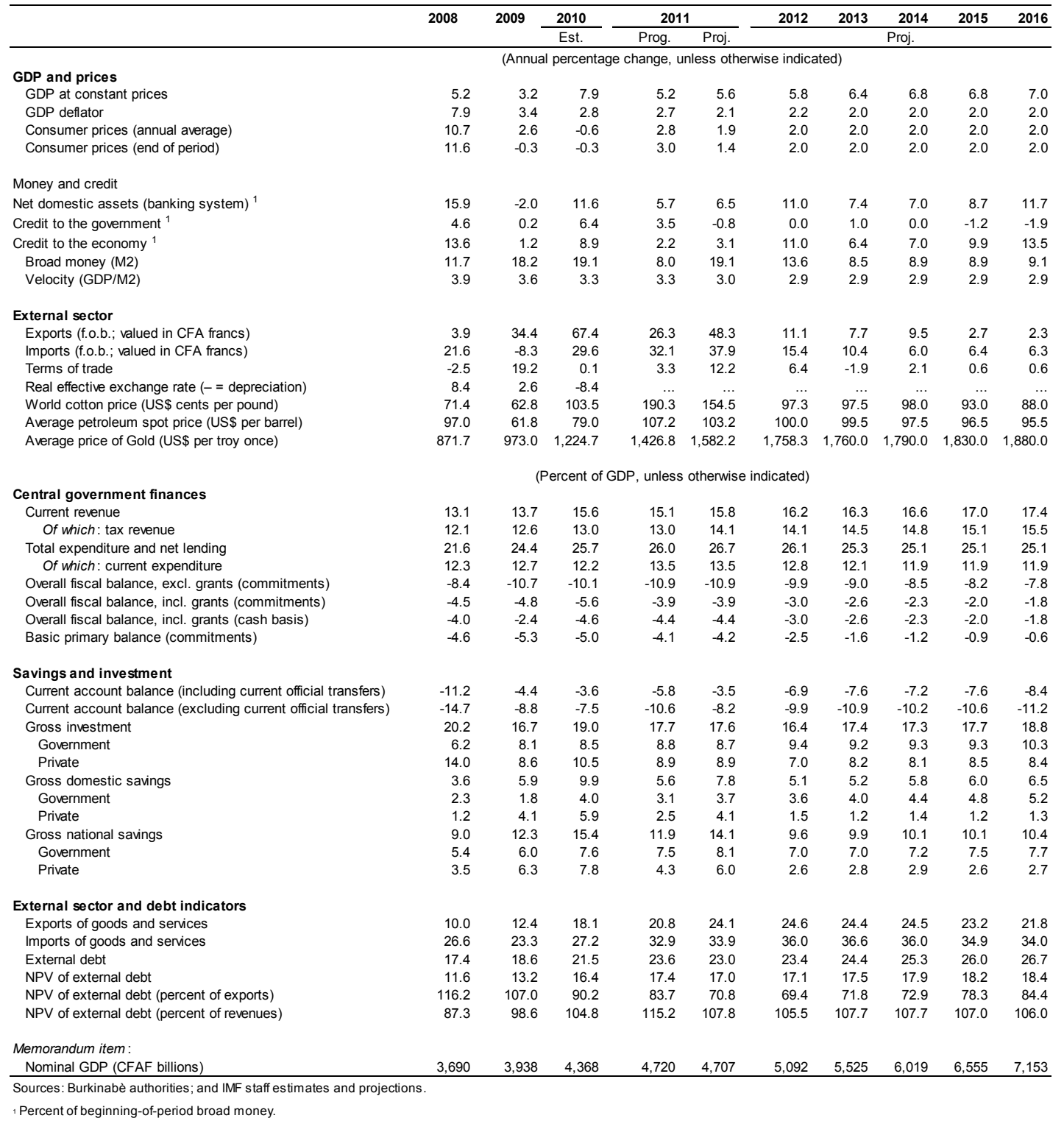

CInternational Monetary Fund. Not for Redistribution 
Table 2. Burkina Faso : Balance of Payments, 2008-16

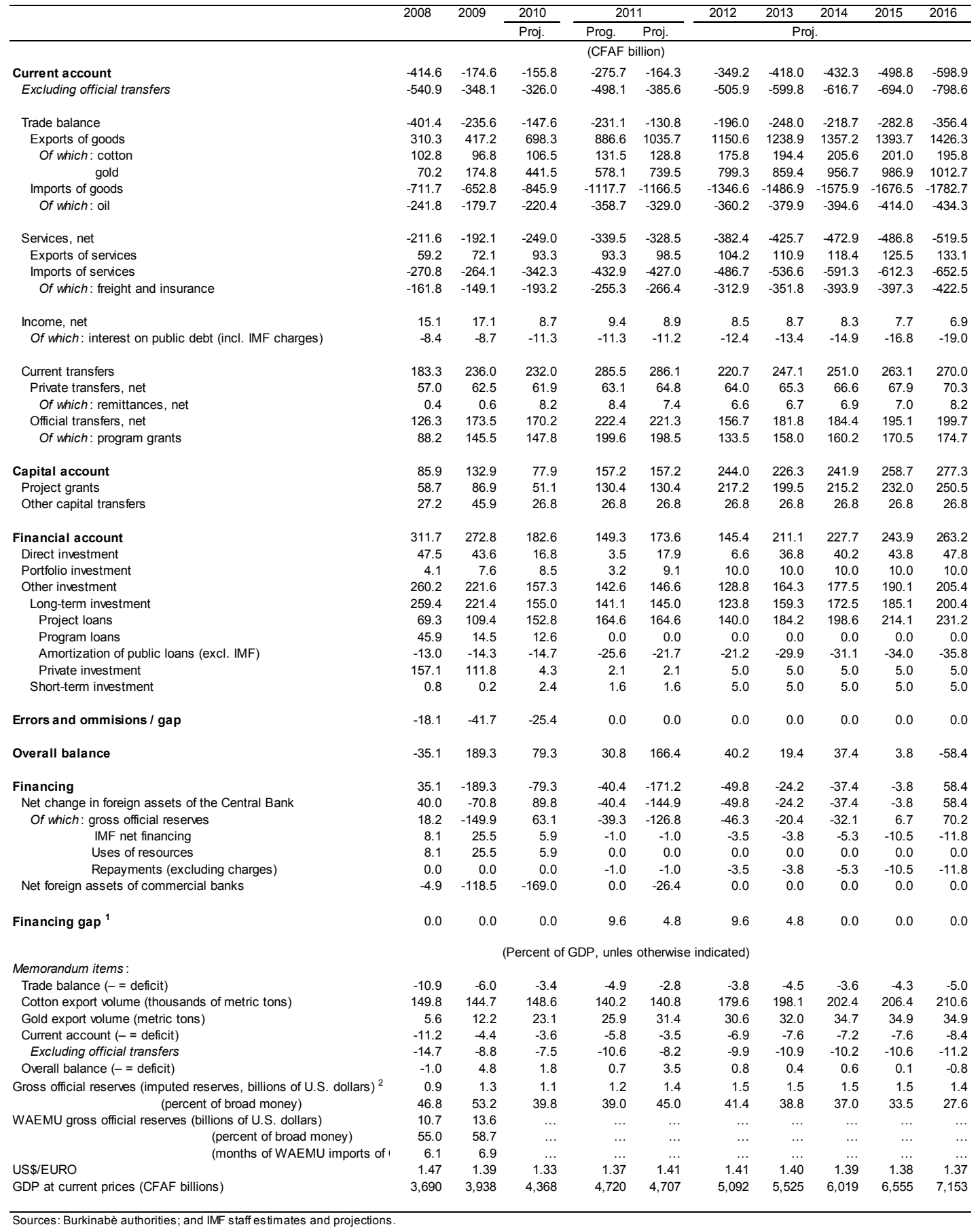

${ }^{1}$ The financing gap is expected to be covered by ECF disbursements as financing from other sources is included in program grants and loans.

${ }^{2}$ Including the Special Drawing Rights allocation of August 2009. 
Table 3. Burkina Faso: Monetary Survey, 2008-16

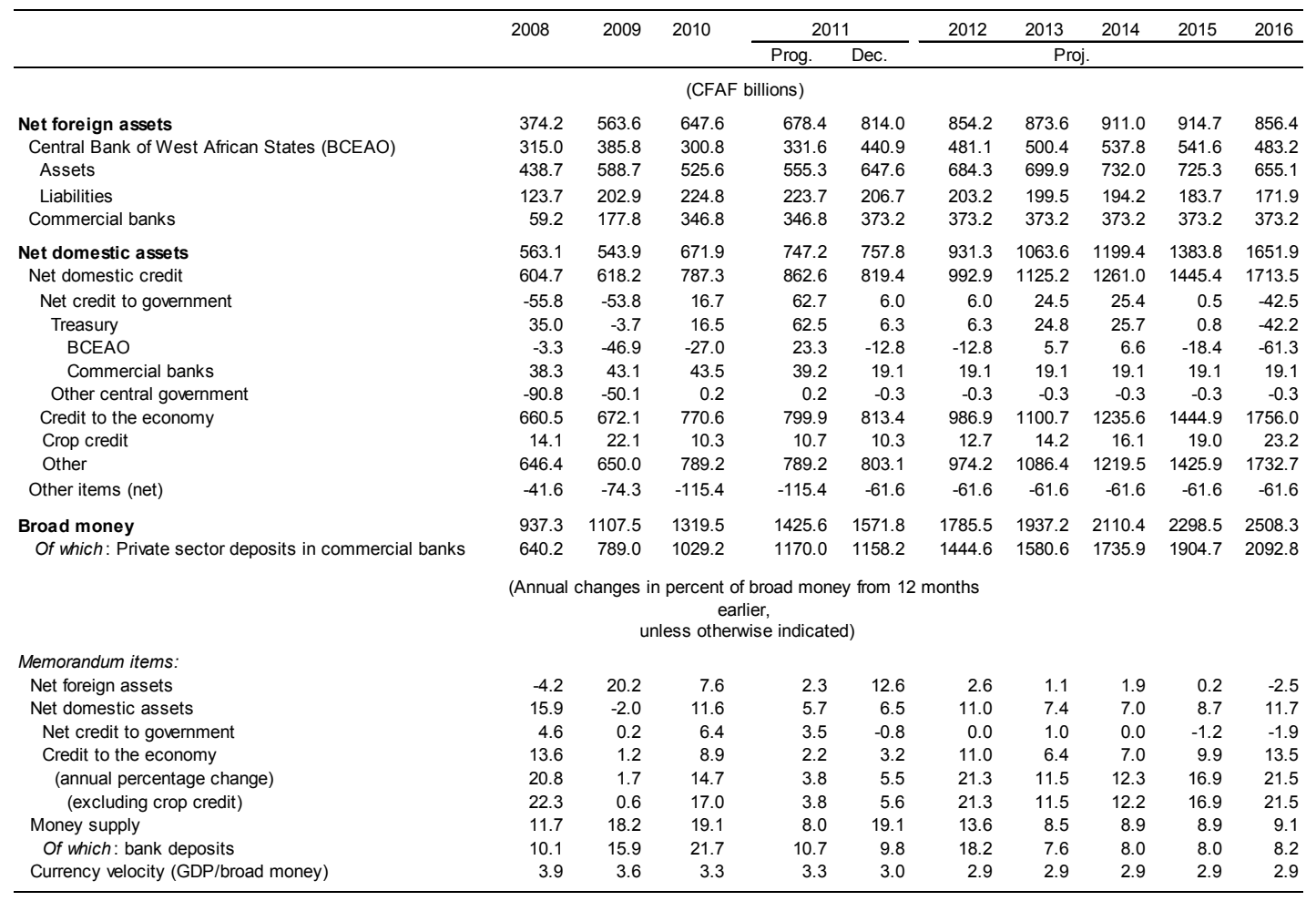

Sources: Burkinabè authorities; and IMF staff estimates and projections. 
Table 4. Burkina Faso: Consolidated Operations of the Central Government, 2008-16

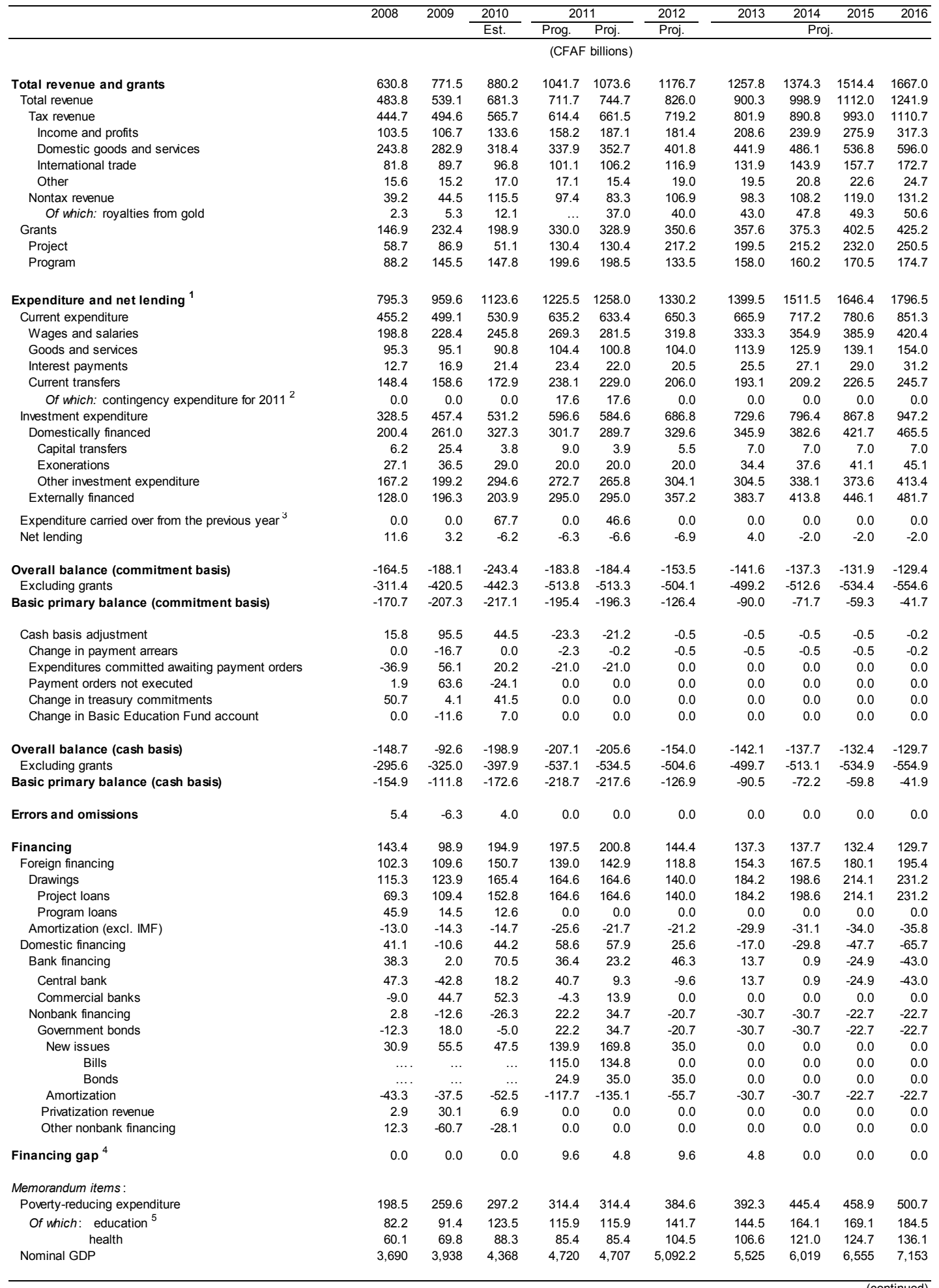


Table 4. Burkina Faso: Consolidated Operations of the Central Government, 2008-16 (concluded)

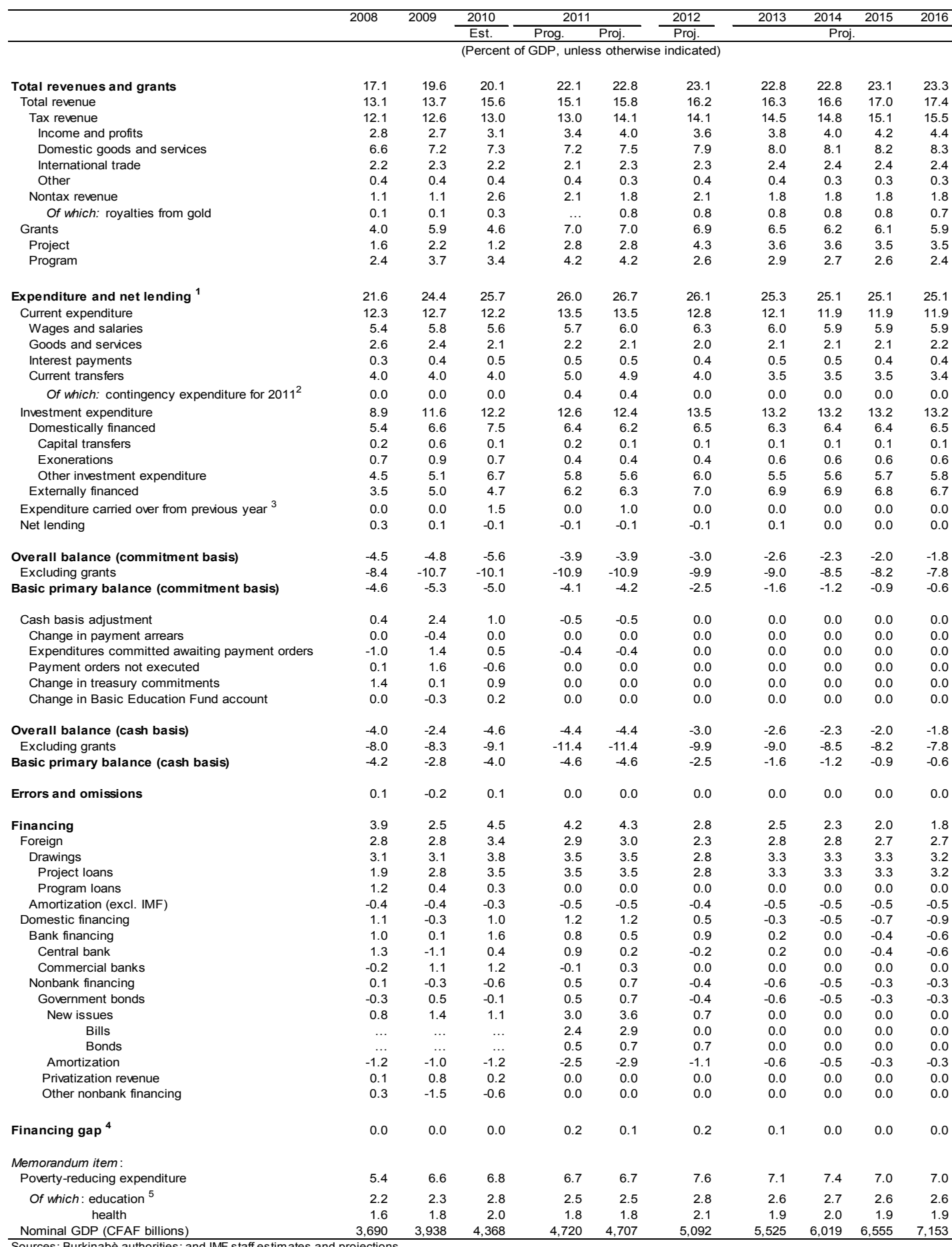

\section{Sources: Burkinabè authoritios; and}

${ }^{1}$ Commitment ("engagement") basis

${ }^{2}$ Contingency expenditure to address the impact of expected exogenous shocks in 2011, should they materialize.

${ }^{3}$ For 2010 and 2011 only.

${ }^{4}$ The financing gap is expected to be covered by ECF disbursements because financing from other sources is included in program grants and loans.

${ }^{5}$ Basic education. 
Table 5. Burkina Faso: Indicators of Capacity to Repay the IMF, 2009-19

\begin{tabular}{|c|c|c|c|c|c|c|c|c|c|c|c|}
\hline & 2009 & 2010 & 2011 & 2012 & 2013 & 2014 & 2015 & 2016 & 2017 & 2018 & 2019 \\
\hline & \multicolumn{11}{|c|}{ Projections } \\
\hline Fund obligations based on existing credit & \multicolumn{11}{|c|}{ (SDR millions) } \\
\hline Principal & 0.0 & 0.0 & 2.4 & 4.7 & 5.1 & 7.2 & 14.1 & 14.4 & 13.5 & 13.1 & 11.0 \\
\hline Charges and interest & 0.2 & 0.0 & 0.1 & 0.2 & 0.2 & 0.2 & 0.2 & 0.2 & 0.1 & 0.1 & 0.1 \\
\hline Fund obligations based on existing and prospective credit & \multicolumn{11}{|c|}{ (SDR millions) } \\
\hline Principal & 0.0 & 0.0 & 2.4 & 4.7 & 5.1 & 7.2 & 14.1 & 16.0 & 18.0 & 20.4 & 20.5 \\
\hline Charges and interest & 0.2 & 0.0 & 0.1 & 0.3 & 0.3 & 0.3 & 0.3 & 0.2 & 0.2 & 0.2 & 0.1 \\
\hline \multicolumn{12}{|l|}{ Total obligations based on existing and prospective credit } \\
\hline SDR millions & 0.2 & 0.0 & 2.5 & 5.0 & 5.4 & 7.5 & 14.4 & 14.5 & 15.4 & 17.6 & 16.2 \\
\hline CFAF billions & 0.1 & 0.0 & 1.8 & 3.7 & 4.0 & 5.5 & 10.7 & 10.7 & 11.4 & 13.0 & 12.0 \\
\hline Percent of exports of goods and services & 0.0 & 0.0 & 0.2 & 0.3 & 0.3 & 0.4 & 0.7 & 0.7 & 0.7 & 0.7 & 0.6 \\
\hline Percent of debt service ${ }^{1}$ & 0.6 & 0.0 & 4.8 & 8.1 & 8.5 & 10.7 & 17.9 & 17.0 & 17.1 & 17.0 & 14.6 \\
\hline Percent of GDP & 0.0 & 0.0 & 0.0 & 0.1 & 0.1 & 0.1 & 0.2 & 0.1 & 0.1 & 0.2 & 0.1 \\
\hline Percent of tax revenue & 0.0 & 0.0 & 0.3 & 0.5 & 0.5 & 0.6 & 1.1 & 1.0 & 0.9 & 1.0 & 0.8 \\
\hline Percent of quota & 0.3 & 0.0 & 4.1 & 8.3 & 9.0 & 12.4 & 23.9 & 24.0 & 25.6 & 29.2 & 26.8 \\
\hline \multicolumn{12}{|l|}{ Outstanding IMF credit } \\
\hline SDR millions & 70.4 & 83.6 & 94.1 & 102.3 & 103.7 & 96.5 & 82.4 & 67.3 & 51.9 & 34.3 & 18.2 \\
\hline CFAF billions & 51.1 & 63.1 & 69.4 & 75.7 & 76.7 & 71.4 & 61.0 & 49.8 & 38.4 & 25.4 & 13.4 \\
\hline Percent of exports of goods and services & 10.5 & 8.0 & 6.1 & 6.0 & 5.7 & 4.8 & 4.0 & 3.2 & 2.3 & 1.4 & 0.7 \\
\hline Percent of debt service ${ }^{7}$ & 221.6 & 252.8 & 185.3 & 167.0 & 163.1 & 139.1 & 102.6 & 79.3 & 57.6 & 33.3 & 16.4 \\
\hline Percent of GDP & 1.3 & 1.4 & 1.5 & 1.5 & 1.4 & 1.2 & 0.9 & 0.7 & 0.5 & 0.3 & 0.1 \\
\hline Percent of tax revenue & 10.3 & 11.1 & 10.5 & 10.5 & 9.6 & 8.0 & 6.1 & 4.5 & 3.2 & 1.9 & 0.9 \\
\hline Percent of quota & 116.9 & 138.9 & 156.3 & 169.9 & 172.2 & 160.3 & 136.8 & 111.7 & 86.2 & 57.0 & 30.2 \\
\hline Net use of IMF credit (SDR millions) & 35.1 & 13.9 & 10.5 & 8.2 & 1.4 & -7.2 & -14.1 & -16.0 & -18.0 & -20.4 & -20.5 \\
\hline Disbursements & 35.1 & 13.9 & 12.9 & 12.9 & 6.5 & 0.0 & 0.0 & 0.0 & 0.0 & 0.0 & 0.0 \\
\hline Repayments and Repurchases & 0.0 & 0.0 & 2.4 & 4.7 & 5.1 & 7.2 & 14.1 & 16.0 & 18.0 & 20.4 & 20.5 \\
\hline \multicolumn{12}{|l|}{ Memorandum items: } \\
\hline Exports of goods and services (CFAF billions) & 489.3 & 791.6 & 1134.2 & 1254.8 & 1349.8 & 1475.6 & 1519.2 & 1559.4 & 1664.1 & 1783.5 & 1889.6 \\
\hline External Debt service (CFAF billions) ${ }^{1}$ & 23.1 & 24.9 & 37.5 & 45.3 & 47.0 & 51.4 & 59.4 & 62.8 & 66.6 & 76.4 & 81.8 \\
\hline Nominal GDP (CFAF billions) & 3,938 & 4,368 & 4,707 & 5,092 & 5,525 & 6,019 & 6,555 & 7,153 & 7,804 & 8,524 & 9,315 \\
\hline Tax Revenue (CFAF billions) & 494.6 & 565.7 & 661.5 & 719.2 & 801.9 & 890.8 & 993.0 & 1110.7 & 1216.0 & 1339.4 & 1476.3 \\
\hline Quota (SDR millions) & 60.2 & 60.2 & 60.2 & 60.2 & 60.2 & 60.2 & 60.2 & 60.2 & 60.2 & 60.2 & 60.2 \\
\hline
\end{tabular}

Source: IMF staff estimates and projections.

${ }^{1}$ Total external debt service includes IMF repurchases and repayments. 
Table 6. Burkina Faso: Schedule of Disbursements Under the ECF Arrangement, 2010-13

\begin{tabular}{|c|c|c|}
\hline Amount & Date Available & Conditions Necessary for Disbursement ${ }^{1}$ \\
\hline SDR 7.454 million & June 14, 2010 & $\begin{array}{l}\text { Following Executive Board approval of the new } \\
\text { ECF arrangement }\end{array}$ \\
\hline SDR 6.45 million & December 15, 2010 & $\begin{array}{l}\text { Observance of the performance criteria for June } \\
30,2010 \text {, and completion of the first review under } \\
\text { the arrangement }\end{array}$ \\
\hline SDR 6.45 million & June 14, 2011 & $\begin{array}{l}\text { Observance of the performance criteria for } \\
\text { December } 31,2010 \text {, and completion of the } \\
\text { second review under the arrangement }\end{array}$ \\
\hline SDR 6.45 million & December 15, 2011 & $\begin{array}{l}\text { Observance of the performance criteria for June } \\
30,2011 \text {, and completion of the third review } \\
\text { under the arrangement }\end{array}$ \\
\hline SDR 6.45 million & June 14, 2012 & $\begin{array}{l}\text { Observance of the performance criteria for } \\
\text { December } 31,2011 \text {, and completion of the fourth } \\
\text { review under the arrangement }\end{array}$ \\
\hline SDR 6.45 million & December 15, 2012 & $\begin{array}{l}\text { Observance of the performance criteria for June } \\
30,2012 \text {, and completion of the fifth review under } \\
\text { the arrangement }\end{array}$ \\
\hline SDR 6.45 million & May 31, 2013 & $\begin{array}{l}\text { Observance of the performance criteria for } \\
\text { December } 31,2012 \text {, and completion of the sixth } \\
\text { review under the arrangement }\end{array}$ \\
\hline
\end{tabular}

Source: IMF Staff.

${ }^{1}$ In addition to the generally applicable conditions under the Extended Credit Facility. 
Table 7. Burkina Faso: Poverty-Reducing Social Expenditure, 2001-11

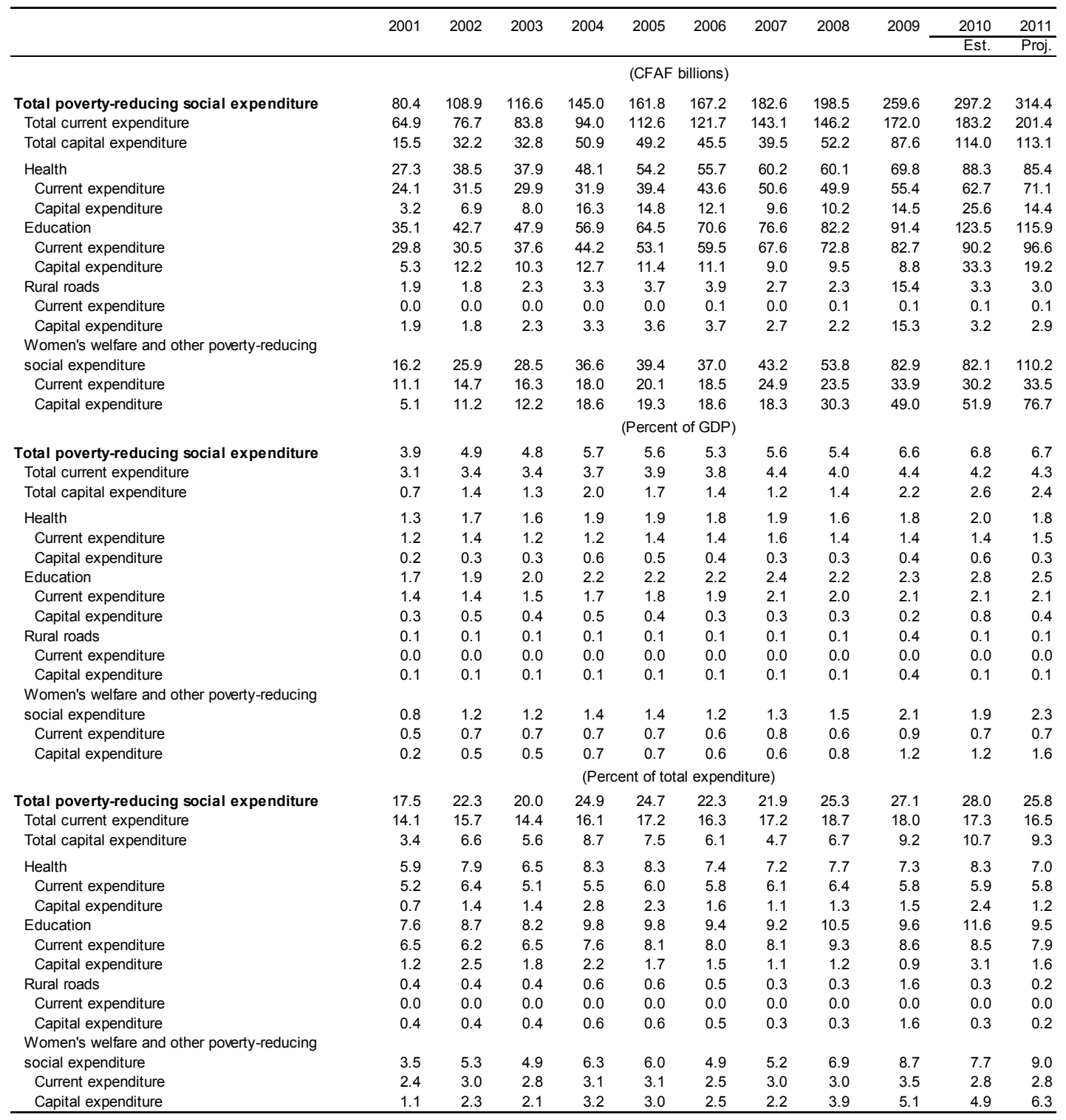

Sources: Burkinabè authorities; and IMF staff estimates and projections. 
Table 8. Burkina Faso: Selected Indicators on the Millennium Development Goals, 1990-2008

\begin{tabular}{|c|c|c|c|c|c|}
\hline & 1990 & 1995 & 2000 & 2005 & 2010 \\
\hline Eradicate extreme poverty and hunger & \multicolumn{5}{|c|}{ (2015 target: halve 1990 US $\$ 1$ a day poverty and malnutrition rates) } \\
\hline Income share held by lowest 20 percent & .. & 5.1 & 5.9 & $6.9^{\wedge}$ & .. \\
\hline Malnutrition prevalence, weight for age (percent of children under 5) & .. & 32.7 & 34.3 & $35.2^{\wedge}$ & $26.0^{*}$ \\
\hline Poverty gap at $\$ 1$ a day (PPP, percent) ${ }^{1}$ & .. & 19.5 & 14.4 & $20.3^{\wedge}$ & .. \\
\hline Poverty headcount ratio at $\$ 1$ a day (PPP) (percent of population) ${ }^{1}$ & 71.2 & 51.4 & 44.9 & $56.5^{\wedge}$ & .. \\
\hline Poverty headcount ratio at national poverty line (percent of population) & .. &.. & 54.6 & $46.4^{\wedge}$ & .. \\
\hline Prevalence of undernourishment (percent of population) & 21.0 & 19.0 & .. & $12.0^{\wedge}$ & $9.0^{* \star *}$ \\
\hline Achieve universal primary education & \multicolumn{5}{|c|}{ (2015 target: net enrollment to 100 ) } \\
\hline Literacy rate, youth total (percent of people ages 15-24) & & .. & & 33.0 & $39.9^{*}$ \\
\hline Persistence to grade 5 , total (percent of cohort) & 70.0 & .. & 69.0 & 72.5 & $75.0^{*}$ \\
\hline Primary completion rate, total (percent of relevant age group) & 20.0 & 20.0 & 25.0 & 31.1 & 46.9 \\
\hline School enrollment, primary (percent net) & 29.0 & .. & 36.0 & 45.3 & $63.3^{*}$ \\
\hline Promote gender equality and empower women & \multicolumn{5}{|c|}{ (2015 target: education ratio 100 ) } \\
\hline Proportion of seats held by women in national parliament (percent) & .. & 4.0 & 8.0 & 11.7 & 15.3 \\
\hline Ratio of girls to boys in primary education (percent) & 61.0 & .. & 70.0 & 80.3 & 91.0 \\
\hline Ratio of girls to boys in secondary education (percent) & .. & .. & .. & 71.0 & 76.2 \\
\hline $\begin{array}{l}\text { Share of women employed in the non-agricultural sector (percent of total } \\
\text { non-agricultural employment) }\end{array}$ & 12.5 & 13.0 & .. & .. & .. \\
\hline Reduce child mortality & \multicolumn{5}{|c|}{ (2015 target: reduce 1990 under 5 mortality by two-thirds) } \\
\hline Immunization, measles (percent of children ages 12-23 months) & 79.0 & 43.0 & 59.0 & 75.0 & $75.0^{*}$ \\
\hline Mortality rate, infant (per 1,000 live births) & 113.0 & 107.0 & 100.0 & 95.4 & 92.6 \\
\hline Mortality rate, under-5 (per 1,000$)$ & 210.0 & 204.0 & 196.0 & 183.5 & 176.2 \\
\hline Improve maternal health & \multicolumn{5}{|c|}{ (2015 target: reduce 1990 maternal mortality by three-fourths) } \\
\hline Births attended by skilled health staff (percent of total) & & 42.0 & 31.0 & 53.5 & $53.5^{\star \star \star}$ \\
\hline Maternal mortality ratio (modeled estimate, per 100,000 live births) & 770.0 & .. & 1000.0 & 600.0 & $560^{* *}$ \\
\hline Combat HIV/AIDS, malaria, and other diseases & \multicolumn{5}{|c|}{ (2015 target: halt, and begin to reverse, AIDS, etc.) } \\
\hline Contraceptive prevalence (percent of women ages 15-49) & .. & 25.0 & 12.0 & 13.8 & $17.4^{\star \star \star}$ \\
\hline Incidence of tuberculosis (per 100,000 people) & 158.0 & 155.0 & 182.0 & 238.0 & $215.0^{*}$ \\
\hline Prevalence of HIV, female (percent ages 15-24) & & .. & .. & .. & $0.8^{*}$ \\
\hline Prevalence of HIV, total (percent of population ages 15-49) & 4.0 & .. & .. & 1.5 & $1.2^{*}$ \\
\hline Tuberculosis cases detected under DOTS (percent) & .. & 11.0 & 17.0 & 11.0 & $14.0^{*}$ \\
\hline Ensure environmental sustainability & \multicolumn{5}{|c|}{ (2015 target: various) } \\
\hline CO2 emissions (metric tons per capita) & 0.1 & 0.1 & 0.1 & 0.1 & $0.1^{* \star *}$ \\
\hline Forest area (percent of land area) & 26.0 & .. & 25.0 & 21.7 & 20.6 \\
\hline GDP per unit of energy use (constant 2000 PPP $\$$ per $\mathrm{kg}$ of oil equivalent) & .. & .. & .. & .. & .. \\
\hline Improved sanitation facilities (percent of population with access) & 7.0 &.. & .. & 11.0 & $11.0^{* *}$ \\
\hline Improved water source (percent of population with access) & 38.0 &.. & .. & 70.0 & $76.0^{* *}$ \\
\hline Nationally protected areas (percent of total land area) & .. &.. & .. & 13.9 & 13.9 \\
\hline Develop a global partnership for development & \multicolumn{5}{|c|}{ (2015 target: various) } \\
\hline Aid per capita (current US\$) & 38.0 & 50.0 & 30.0 & 48.8 & $67.8^{*}$ \\
\hline $\begin{array}{l}\text { Debt service (PPG and IMF only, percent of exports of goods and services, } \\
\text { excl. workers' remittances) }\end{array}$ & 7.8 & 14.6 & 20.3 & 8.3 & $6.3^{*}$ \\
\hline Internet users (per 1,000 people) & 0.0 & 0.0 & 1.0 & 4.5 & $11.1^{*}$ \\
\hline Personal computers (per 1,000 people) & 0.0 & 0.0 & 1.0 & .. & .. \\
\hline Total debt service (percent of exports of goods, services and income) & 6.8 & 11.9 & 14.9 & .. & .. \\
\hline Unemployment, youth female (percent of female labor force ages 15-24) & .. & .. & .. & .. & .. \\
\hline Unemployment, youth male (percent of male labor force ages 15-24) & .. & .. & .. &.. & .. \\
\hline Unemployment, youth total (percent of total labor force ages 15-24) & .. & .. & .. & .. & .. \\
\hline \multicolumn{6}{|l|}{ Other } \\
\hline Fertility rate, total (births per woman) & 6.9 & 6.9 & 6.5 & 6.0 & $5.9^{*}$ \\
\hline GNI per capita, Atlas method (current US\$) & 350.0 & 240.0 & 250.0 & 390.0 & 550.0 \\
\hline GNI, Atlas method (current US\$) (billions) & 2.9 & 2.4 & 2.8 & 5.5 & 9.0 \\
\hline Gross capital formation (percent of GDP) & 18.2 & 22.8 & 22.7 & 20.4 & $18.1^{* \star *}$ \\
\hline Life expectancy at birth, total (years) & 48.0 & 46.0 & 47.0 & 52.4 & $54.4^{*}$ \\
\hline Literacy rate, adult total (percent of people ages 15 and above) &.. & .. & .. & 23.5 & $28.7^{\star * \star}$ \\
\hline Population, total (millions) & 8.5 & 9.8 & 11.3 & 14.2 & 16.5 \\
\hline Trade (percent of GDP) & 35.4 & 40.7 & 34.3 & 35.6 & $38.3^{\star \star \star}$ \\
\hline
\end{tabular}

Note: * refers to 2009 data ** refers to 2008 data ${ }^{* * *}$ refers to 2007 data $\wedge$ refers to 2003 data

\$1.25 as of 2008 .

Source: World Development Indicators database, 2011. 


\title{
APPENDIX I-LETTER OF INTENT
}

Ouagadougou, December 7, 2011

\author{
Christine Lagarde \\ Managing Director, \\ International Monetary Fund \\ $70019^{\text {th }}$ Street NW \\ WASHINGTON, DC 20431 (USA)
}

\section{Dear Mrs. Lagarde:}

1. The government of Burkina Faso remains determined to address the country's developmental challenges, as reflected in the ambitious goals set in the PRPS.

2. Despite a difficult social and regional environment in the first half of the year, the government maintained the course for economic policies, while taking mitigating measures to address the impact of the exogenous shocks. Despite these shocks, however, economic prospects for 2011 and 2012 are promising. Economic growth is expected to be in line with projections for both years, while inflationary pressures should be moderate. Nonetheless, the government is committed to fiscal discipline to consolidate recent progress in fiscal sustainability, and support macroeconomic stability.

3. The government maintained sound policies, and implemented its economic and financial program supported by the IMF under the Extended Credit Facility in a satisfactory manner. As a result, at end-June 2011, all quantitative performance criteria, and all indicative targets, except for the one on poverty reducing spending were met and, most structural reforms measures were implemented. Furthermore, as indicated in the attached MEFP, the government maintains its resolve on reform implementation and prudent fiscal management. Therefore, it is convinced that program objectives for endDecember 2011 are reachable, as reflected in the 2011 supplementary budget, in the case of fiscal objectives.

4. The draft budget for 2012 is consistent with the programmed fiscal targets. It calls for continued revenue mobilization efforts and prudent expenditure management. In particular, the government intends to increase capital and pro-poor expenditure to support its growth and poverty reduction objectives, and to ensure that the wage policy remains consistent with medium-term fiscal sustainability. In this vein, the agreement reached with labor unions on November 29, 2011 is fully consistent with this objective. As a result, the overall fiscal deficit budgeted for 2012 stands at 3 percent of GDP, down from 3.9 percent of GDP in 2011.

5. The government is convinced that the economic and financial policies presented in the attached Memorandum of Economic and Financial Policies (MEFP) support the achievement of medium-term objectives, and in particular, those set under our ECF- 
supported program. It is determined to take any additional measures that may become necessary to reach the objectives. Should such measures become necessary, the government will consult with the IMF before their adoption, and before any revision to policies outlined in the MEFP, in accordance with the Fund's policies on such consultation. Furthermore, the government will provide the IMF with information on policy and reform implementation, as agreed under the attached Technical Memorandum of Understanding, or upon request.

6. In view of the strong program performance and policy commitments outlined in the MEFP attached to this letter, the government of Burkina Faso requests the completion of the third ECF review, and the fourth disbursement totaling SDR 6.45 million.

7. As was the case in the past, the government authorizes the IMF to publish this Letter of Intent and its attachments, as well as the staff report, upon approval by the IMF Executive Board.

Sincerely yours,

\author{
$/ \mathrm{s} /$ \\ Lucien Marie Noël BEMBAMBA \\ Minister of Economy and Finance \\ Officier de l'Ordre National
}

Attachments: Memorandum of Economic and Financial Policies, 2011-12

Technical Memorandum of Understanding 


\section{APPENDIX I--ATTACHMENT I \\ Memorandum OF ECONOMIC AND FinANCIAL Policies FOR 2011-12}

DECEMBER 7, 2011

\section{Introduction}

1. The economic and financial program of Burkina Faso, supported by the International Monetary Fund (IMF) under the Extended Credit Facility (ECF) is intended to consolidate macroeconomic stability, enhance growth prospects, and step up the fight against poverty, in line with the objectives of the Strategy for Accelerated Growth and Sustained Development (SCADD). This memorandum of economic and financial policies taking stock of the program's implementation as of end-June 2011, and outlines economic policies and reforms that the government intends to undertake to achieve the objectives set in its economic and financial program for the remainder of 2011 and 2012. It supplements the Letter of Intent from the Minister of Economy and Finance, as well as the Memorandum of Economic and Financial Policies of June 28, 2011.

\section{Recent Economic Developments and Program Implementation at end-June 2011}

\section{A. Recent Economic Developments}

2. Economic activity was affected by social unrest during the first half of 2011. Nonetheless, economic growth is expected to stand at 5.6 percent, supported primarily by continued dynamism in the mining sector and the recovery of cotton production. The mining sector should benefit from the expected expansion in production, projected at 21.3 percent, and the coming on stream of a manganese mine, with a projected production of 60,000 tons. The production of cottonseed should rise by 21.7 percent for the $2010 / 11$ crop year. This increase is partly due to the continued support to producers and the increasing use of genetically-modified cottonseeds. As for consumer prices, annual average inflation is projected at 1.4 percent, well below the 3 percent WAEMU convergence criterion, reflecting essentially the impact of a good harvest from the 2009/10 crop year, and the favorable outlook for the 2010/2011 food crop.

3. The external position of Burkina Faso should improve in 2011. Net capital inflows, particularly in the form of budgetary assistance and the CFAF 30 billion in foreign assistance expected under the Millennium Challenge Account, should offset the projected deficit on the current account (excluding grants) and support a sharp improvement in the overall balance of payments, compared to 2010.

4. Money supply was up by 6.1 percent in June 2011 compared with end-December 2010. The increase was essentially due to rise in credit to the private sector, as well as a significant use of bank financing by the Treasury, caused in part by the low disbursement 
rate of budgetary support at end-June. The increase in net credit to the government and in credit to the economy thus contributed to a rise in net domestic assets, which more than offset the decline in net foreign assets.

5. The financial system remains sound overall. The majority of banks continues to uphold prudential standards and are sufficiently capitalized according to the new regional rules. Moreover, they have remained active on the regional bond market and were not adversely affected by the post-election crisis in Côte d'Ivoire at the beginning of the year.

6. On the fiscal front, performance on the revenue side was strong at end-June 2011, while there were some weaknesses on expenditure execution. Revenues were in fact 11.4 percent higher than anticipated, thanks to measures to strengthen the revenue collection units and make them more accountable. Expenditure execution was weaker than expected, reflecting delays in the procurement process which, combined with the impact of social unrest, had an adverse impact on both investment and social spending in the first six months of the year. The midterm implementation review of the 2011 budget produced a number of recommendations that are expected to improve the execution rate for capital expenditure in the context of a new supplementary budget for 2011, submitted to the National Assembly in September. Budget execution during the first half of 2011 revealed the need for further adjustments to the budgetary closeout framework introduced in 2010, in order to ensure closer adherence to the budget calendar.

\section{B. Results of Program Implementation}

7. The majority of program objectives for end-June were met. The total revenue floor of CFAF 347.6 billion was exceeded by 11.4 percent, as revenue topped 387.3 billion. Moreover, thanks to ongoing efforts to ensure closer monitoring of businesses, the large taxpayer non-filer rate was 2.3 percent compared to a program target of 5 percent for end-June: 2 percent for the VAT, 5 percent for the IUTS (tax on wage income) and 2 percent for the IMF (minimum tax on businesses) - with a taxpayer follow-up rate of 100 percent. The performance criteria on overall budget deficit set at CFA 91 billion was met despite the shortfall in budgetary assistance experienced at endJune. However, social spending fell short of objectives, in part because of delays in the execution of capital expenditures. The government maintained a prudent foreign borrowing policy: it neither contracted nor guaranteed debt on non-concessional terms. Nor did it accumulate domestic payment arrears.

8. Most structural measures set for end-June 2011 were met (see Table 1 below). These include in particular the completion of the audit of finance and administration units (DAFs); implementation of the integrated external financing system; and completion of the study on mechanisms for financing the price-smoothing fund. The recommendations from that study were used to establish a new system for setting producer prices as of the 2011/12 cotton year. However, the study on the inputs fund was completed after the scheduled date of end-June 2011 because of data collection problems. 
9. With respect to fiscal reforms, the following measures were taken:

- $\quad$ As part of the antifraud campaign, two scanners were purchased for the customs offices at Ouagadougou (road) and Bobo Dioulasso (station) and a startup test was conducted at Ouagadougou. Corrective maintenance, preparation of an operating procedures manual, and a public information and awareness campaign are on course for implementation by the end of the year. However, the ORBUS customs preclearance system will be deployed late, as it took longer than expected to obtain the consent of the principal financing partner supporting this component of customs facilitation reforms.

- $\quad$ For reducing payment times, a Council of Ministers adopted a decree on July 27, 2011 instituting budget expenditure verification units in line ministries and institutions. Arrangements are now in place to make five verification units operational on a pilot basis.

- $\quad$ The Technical Secretariat of the Budget Execution and Cash Management Monitoring Committee is now responsible for validating the data in the government flow-of-funds table (TOFE) before its submission to the Committee, which meets monthly. This step will further strengthen the reliability of data in the TOFE and reduce the time taken to complete it.

10. There has been significant progress in preparations for the transition to a resultsbased budgeting framework by 2017, as recommended by WAEMU. The principal steps taken in 2010 related to: (i) adoption of a conceptual memorandum by the Council of Ministers; (ii) organization of stakeholder awareness campaigns, including in the regions; and (iii) development of a methodological guide on the preparation of program budgets. That document was used as the basis for preparing program budgets for the seven pilot ministries in 2010.

11. With respect to internalizing WAEMU fiscal directives, a work schedule was adopted in January 2011 and three subcommittees finalized drafts of the following texts: (i) preliminary draft law on the transparency code, (ii) preliminary draft budget law, (iii) draft decree issuing general regulations on government accounting, (iv) draft decree establishing the legal regime applicable to government accounting officers, and (v) draft decree establishing the TOFE. These texts are expected to be validated by end-2011 and introduced for adoption by the National Assembly.

12. Measures to strengthen debt management capacity were pursued, including the following:

- $\quad$ Preparation of an action plan to address the vulnerabilities noted in the Debt Management Performance Assessment (DEMPA) prepared by the World Bank during the March 2011 mission. 
- Inclusion of a risk analysis in the annual indebtedness strategy for 2012. However, there is still a need to strengthen risk analysis capabilities, and a request has been made to the IMF Institute for an on-site training course for selected staff.

- Training for staff involved in introducing the Integrated External Finance System.

- $\quad$ To facilitate use of the borrowing and debt management procedures manual adopted in 2009, training sessions were held for 63 officers during June 2011.

13. The authorities pursued reforms in the cotton sector. Actions to strengthen the management of SOFITEX were furthered, and the main recommendations from the study on the price-smoothing fund were implemented. The study on the inputs fund is expected by end-October 2011. The authorities have also begun work on an action plan to implement the strategy for reducing the government's stake in SOFITEX.

14. With respect to the financial sector development strategy, the following actions were taken: (i) a note was prepared outlining the strategy for restructuring the postal services including the overhaul of the information system, an improvement in the reliability of the postal financial services files, and a review of the organizational structure of SONAPOST; (ii) systematic and regular supervision was established for insurance companies and brokerage firms and the list of insurance agents and brokers was updated by the Insurance Directorate; and (iii) a workshop was held to validate the new microfinance development strategy in October 2011.

15. Progress was made with regard to implementation of a new pricing mechanism for petroleum products. The provisional report from the study was examined in March 2011 by a consulting firm, which provided guidance for finalizing the study in June 2011 during a validation workshop. The final report will be submitted to the Council of Ministers for review and adoption so that the new system can be implemented by endDecember 2011.

\section{Economic Policies for 2011-12}

\section{A. Macroeconomic Framework}

16. The government intends to pursue strategies and actions to support growth and reduce poverty, in the context of the SCADD. For 2012, economic growth is projected at 5.8 percent, average inflation at around 2 percent, and the external current account deficit at 6.9 percent.

17. To achieve these objectives, the government will focus on: (i) vigorous pursuit of steps to strengthen fiscal progress to date, in terms both of revenue mobilization and of expenditure and cash management; (ii) implementation of structural reforms; and (iii) strengthening of social policy; and (iv) implementation of the measures and programs planned in the SCADD. 


\section{B. Fiscal Policy}

18. Fiscal policy will focus on maintaining growth by boosting public investment and supporting private sector investment within a sustainable macroeconomic and financial framework. In 2011, the overall fiscal deficit (on a commitments basis, excluding grants) is projected at 10.9 percent of GDP, slightly up from 2010, despite higher revenues. The deficit will be financed by budgetary assistance from the country's development partners within the general framework for the organization of budget support, expected disbursements from the IMF, and a bond issue on the WAEMU market.

19. Revenue is projected at 16.2 percent of GDP in 2012, compared to 15.8 percent of GDP in 2011. This increase reflects the recovery in economic activity, continued organizational improvements in the revenue collecting units, implementation of the new tax provisions adopted in 2010, and higher international gold prices. Non-tax revenue collection will also benefit for the payment of telecommunication revenue for the fourth mobile telephone license.

20. Total expenditure and net lending should amount to 26.1 percent of GDP in 2012 compared to 26.7 percent of GDP in 2011. Expenditure control remains an important objective of the government. Thus, nominal increase in spending would be modest, while reflecting the objective of supporting economic recovery. In this context, while spending for priority sectors would rise, current expenditure would drop from 13.5 percent of GDP in 2011 to 12.8 percent of GDP in 2012.

21. Capital expenditure is projected to rise to 13.5 percent of GDP in 2012, to support the economic recovery and achieve the growth objectives in the SCADD. Expenditure priority areas would be: (i) boosting support for rural development, including rehabilitation of dams and reservoirs; (ii) improving the areas surrounding the dams to make more farmland available; (iii) developing economic infrastructure; (iv) intensifying efforts to fight poverty; and (v) promoting employment and reducing unemployment, particularly among young people and women.

22. Regarding the wage bill, the government intends to respond to claims from labor union following the social unrest earlier this year, to increase purchasing power for civil servants. Nonetheless, the government plans to address these demands while ensuring that the wage policy remains consistent with medium-term fiscal sustainability objectives. Therefore, the government plans to accelerate civil service reforms programmed for 2012, and to take additional measures aimed at reducing inequities in the compensation system for civil servants. Some of the measures will have a financial impact that will increase the wage bill from 6 percent of GDP in 2011 to 6.3 percent of GDP in 2012. Nonetheless, the real impact could be lower because of savings expected from civil service reforms in 2011-12. Moreover, the government believes that the planned reforms would strengthen the wage policy and make the merit-based promotion system more efficient. More generally, a better control on the size of the civil service through the setting up of biometrics card, and merit-based promotion would contribute to a deceleration in the 
wage bill over the medium term. The key measures programmed for 2011-12 are the following:

- $\quad$ The extension in the last quarter of 2011 of the housing and advising allowances to civil servants that did not benefit from these allowances at end-June 2011.

- $\quad$ Clearance of late payments in promotions granted during 2009-2010 and timely payment of 2011 promotions, in 2011.

- $\quad$ Increase of the base salary by 5\% in 2012 .

- $\quad$ Preparation of a diagnostic study on the compensation system by end-December 2012 (Structural benchmark); and the launching of the civil service census in December 2011. Results from the census would lead to the harmonization of the payroll system and the civil service roster, and the efficient setting up of the biometrics card for civil servants.

\section{Borrowing Policy and Debt Management}

23. The government is committed to a prudent borrowing policy in order to avoid over-indebtedness, while mobilizing significant resources to finance growth. It intends to pursue its policy of relying on grants and concessional loans to meet its financing needs.

24. Efforts to strengthen the government's debt management capacity will continue in 2011-12. In particular, steps will be taken to correct the shortcomings noted by the World Bank DEMPA mission of March 2011, with particular emphasis on developing a medium-term debt management strategy, for which the government intends to request technical assistance from the IMF and the World Bank, improving debt auditing, and holding training activities.

\section{Social Policy}

25. With respect to efforts to support the most vulnerable groups, and more generally to fight poverty, social spending is anticipated to amount to 7 percent of GDP in 2012. The following actions are planned for 2012:

- $\quad$ Strengthening of the social safety nets, in particular the school lunches program and obstetrical care.

- Launch of an ambitious employment program for young people and women, funded with CFAF 10 billion and supported by several technical and financial partners.

- Implementation of priority items in the action plan for the national social protection policy (PNPS) now in preparation. A national forum to validate the proposed PNPS is planned for November 2011. 


\section{E. Implementation of the SCADD}

26. The 2011-2013 performance matrix for the SCADD adopted on September 30, 2011, calls for:

- Launching the work on sources of growth. In this context, the government plans to begin implementation of the pilot Bagré growth project; adopt a law to develop public-private partnerships, adopt an inputs strategy to support agricultural productivity; carry out the technical work on national backbone infrastructure to speed the introduction of information and communication technologies; manage the industrial zones of Ouagadougou and Bobo-Dioulasso sustainably; and adopt a new mining code and regulations.

- $\quad$ Consolidating human capital. The government plans to expedite the implementation of the program for construction of school and health infrastructure, as well as measures to match training and employment opportunities through the development of technical education and vocational training.

\section{Structural Reforms for 2011-12}

\section{A. Financial Sector}

27. In the financial sector, the government plans to deepen reforms by further implementing the financial sector development strategy. To this end, the government will seek to establish a framework conducive to greater competition among financial sector participants; to promote the insurance sector, while pursuing activities underway in the CNSS to strengthen its solvency over the medium and long term; to improve access to financing in rural areas and for small and medium-sized enterprises; to boost financing for housing and access to ownership; and to improve the legal and judicial framework essential to the financial system and its stability.

28. To improve SME access to financial services, the government will promote the microfinance sector by strengthening its institutional framework. It also plans to adopt and implement, by December 2011, the new microfinance development strategy and its action plan.

\section{B. Public Finance Reforms}

29. Efforts to improve expenditure management will be pursued. Particular emphasis will be placed on further reducing payment times, stricter monitoring of the expenditure system in the line ministries, and implementation of the recommendations from the audits of the financial administration directorates. The following measures are planned by endSeptember 2012:

- Benchmarking of new functionalities in the expenditure system to shorten payment times. 
- Option for computerized rejection of irregular supplier submissions when the grounds for rejection are attributable to the supplier.

- Introduction of acknowledgment of receipt to make staff more accountable for meeting timeliness standards.

- In order to ensure timely processing, expenditure verifications (liquidations) not processed within a certain time limit by appropriations managers will be automatically abandoned.

30. In order to strengthen capital budget execution and improve the business environment, a meeting will be held in November 2011 with all persons involved in government procurement procedures to identify ways of improving those procedures. The government also intends to continue the practice of advance planning for procurement, to train the members of procurement sub-commissions, and to step up the monitoring of procurement plans.

31. In preparation for the transition to results-based budgeting, all ministries and institutions will be expected to define their programs in 2011, consistent with the SCADD and the Millennium Development Goals. Burkina Faso intends to respect the Community target of moving to results-based budgeting by 2017. In this context, the medium-term expenditure framework will remain a very important tool for meeting the objectives of the SCADD.

\section{Program Monitoring}

32. The authorities intend to take all measures necessary to achieve the objectives and benchmarks agreed with IMF staff, as presented in Tables 1 and 2 of this memorandum. The program will be monitored in accordance with the Technical Memorandum of Understanding, which defines quantitative performance criteria and requirements for data reporting to IMF staff. The program will be reviewed twice yearly. For the duration of the program, the government undertakes not: (i) to introduce restrictions on payments and transfers under current international transactions or tighten any such restrictions without prior consultation with the IMF; (ii) to introduce or modify multiple currency practices; (iii) to conclude bilateral payment agreements incompatible with the provisions of Article VIII of the IMF Articles of Agreement; or (iv) to introduce restrictions on imports for balance of payments purposes.

33. Program reviews: the conclusion of the fourth program review, scheduled for June 15, 2012, is conditional upon the observance of performance criteria for December 31, 2011; the conclusion of the fifth program review, scheduled for December 15, 2012, is conditional upon the observance of performance criteria for June 30,2012; and the conclusion of the sixth program review, scheduled for May 31, 2013, is conditional upon the observance of performance criteria for December 30, 2012. 


\begin{tabular}{|c|c|c|c|c|c|}
\hline & \multirow{3}{*}{$\frac{2011}{\text { Proj. }}$} & \multicolumn{4}{|c|}{2012} \\
\hline & & Mar. ${ }^{5}$ & Jun. ${ }^{6}$ & Sep. ${ }^{5}$ & Dec. ${ }^{6}$ \\
\hline & & Proj. & Proj. & Proj. & Proj. \\
\hline \multicolumn{6}{|l|}{ Performance criteria and benchmarks } \\
\hline $\begin{array}{l}\text { Ceiling on the overall fiscal deficit including grants }{ }^{1} \\
\text { Ceiling on the amount of new nonconcessional external debt contracted or guaranteed by }\end{array}$ & 184.6 & 51.6 & 91.1 & 122.8 & 154.0 \\
\hline the government ${ }^{2,3}$ & 0.0 & 0.0 & 0.0 & 0.0 & 0.0 \\
\hline $\begin{array}{l}\text { Ceiling on the amount of new external debt of less than one year's maturity contracted or } \\
\text { guaranteed by the government } 2,3\end{array}$ & 0.0 & 0.0 & 0.0 & 0.0 & 0.0 \\
\hline Accumulation of external arrears ${ }^{2}$ & 0.0 & 0.0 & 0.0 & 0.0 & 0.0 \\
\hline \multicolumn{6}{|l|}{ Indicative targets } \\
\hline Government revenue & 744.7 & 168.3 & 349.5 & 521.7 & 826.0 \\
\hline Poverty-reducing social expenditures & 314.4 & 84.6 & 176.9 & 280.7 & 384.6 \\
\hline Large taxpayer non-filer rate (percent) ${ }^{4}$ & 5.0 & 5.0 & 5.0 & 5.0 & 5.0 \\
\hline Accumulation of domestic arrears & 0.0 & 0.0 & 0.0 & 0.0 & 0.0 \\
\hline \multicolumn{6}{|l|}{ Maximum upward adjustment of deficit ceiling including grants due to: } \\
\hline Shorffall in grants relative to program projections & 25.0 & 25.0 & 25.0 & 25.0 & 25.0 \\
\hline Excess in concessional loan financing relative to program projections & 15.0 & 15.0 & 15.0 & 15.0 & 15.0 \\
\hline \multicolumn{6}{|l|}{ Adjustment factors } \\
\hline Shortfall in grants relative to program projections & 0.0 & 0.0 & 0.0 & 0.0 & 0.0 \\
\hline Excess in concessional loan financing relative to program projections & 0.0 & 0.0 & 0.0 & 0.0 & 0.0 \\
\hline \multicolumn{6}{|l|}{ Memorandum items: } \\
\hline Basic primary balance (cash basis) & -217.6 & -36.8 & -89.1 & -148.9 & -126.9 \\
\hline Grants & 328.9 & 35.0 & 124.7 & 291.9 & 350.6 \\
\hline Concessional loans & 164.6 & 17.5 & 35.0 & 87.5 & 140.0 \\
\hline \multicolumn{6}{|c|}{$\begin{array}{l}\text { Sources: Burkinabè authorities; and IMF staff estimates and projections. } \\
1 \text { The ceiling on the overall fiscal deficit is to be adjusted in line with the TMU definition. It is calculated on a commitment basis. } \\
2 \text { To be observed continuously. } \\
{ }^{3} \text { Excluding treasury bills and bonds issued in CFA francs on the regional West African Economic and Monetary Union (WAEMU) market. } \\
\text { This ceiling excludes supplier credit with a maturity of one year or less. } \\
{ }^{4} \text { Applies to average over respective quarter. } \\
5 \text { Indicative target. } \\
{ }^{6} \text { Performance criteria. }\end{array}$} \\
\hline
\end{tabular}


Table 2. Structural Benchmarks, July 2011 - June 2012

Measures
Public financial management
Implement a new pricing and taxation system for
petroleum products.

Set up a one-stop window for customs clearance.

Set up an electronic system to improve merchandise valuation in two customs posts.

Installation of units in charge of expenditure control in five departments.

\section{Public service}

Complete the civil service survey and harmonize the payroll and the civil service roster.

Implement the biometric card for civil servants in three pilot institutions.

Prepare a study on the compensation system

\section{Cotton sector}

Prepare a strategy for the gradual reduction of state participation in the capital structure of SOFITEX.

\section{Financial sector}

Implement the microfinance strategy.

Prepare a strategy to enhance the quality of financial services offered by the SONAPOST.
End-Dec. 2011

(New date -

Fourth review )

End-Dec. 2011

(New date -

Fourth review)

End-Dec. 2011

(Fourth review)

End-Dec. 2011

(Fourth review)

End-March 2012

(Fifth review)

End-Dec. 2011

(Fourth review)

End-June 2012

(Fifth review)

End-Dec. 2012

(Sixth Review)

End-June 2012

(Fifth review)

End-June 2012 (Fifth review) 


\title{
APPENDIX I--ATTACHMENT II \\ TECHNICAL MEMORANDUM OF UNDERSTANDING
}

\author{
Ouagadougou, December 7, 2011
}

1. This technical memorandum of understanding (TMU) defines the quantitative performance criteria and indicative targets, as well as structural benchmarks to assess performance under the program supported by the Extended Credit Facility (ECF). It also sets deadlines for data reporting.

\section{DEFINITIONS}

2. Government. Unless otherwise indicated, "government" means the central administration of Burkina Faso and does not include any local administration, the central bank, or any other public or government-owned entity with autonomous legal personality not included in the government flow-of-funds table (TOFE).

3. Definition of debt. For the purposes of the relevant assessment criteria, the definition of debt is set out in Executive Board Decision No.6230-(79/140), Point 9, as revised on August 31, 2009 (Decision No. 14416-(09/91)).

a) the term "debt" will be understood to mean a current, i.e., not contingent, liability, created under a contractual arrangement through the provision of value in the form of assets (including currency) or services, and which requires the obligor to make one or more payments in the form of assets (including currency) or services, at some future point(s) in time; these payments will discharge the principal and/or interest liabilities incurred under the contract. Debts can take a number of forms, the primary ones being as follows:

i. loans, i.e., advances of money to the obligor by the lender made on the basis of an undertaking that the obligor will repay the funds in the future (including deposits, bonds, debentures, commercial loans and buyers' credits) and temporary exchanges of assets that are equivalent to fully collateralized loans under which the obligor is required to repay the funds, and usually pay interest, by repurchasing the collateral from the buyer in the future (such as repurchase agreements and official swap arrangements);

ii. suppliers' credits, i.e., contracts where the supplier permits the obligor to defer payments until sometime after the date on which the goods are delivered or services are provided; and

iii. leases, i.e., arrangements under which property is provided which the lessee has the right to use for one or more specified period(s) of time that are usually shorter than the total expected service life of the property, while the lessor retains the title to the property. For the purpose of the guideline, the debt is the present value (at the inception of the lease) of all lease payments expected to be made during the period of the agreement excluding those payments that cover the operation, repair or maintenance 
of the property.

b) Under the definition of debt above, arrears, penalties, and judicially awarded damages arising from the failure to make payment under a contractual obligation that constitutes debt are debt. Failure to make payment on an obligation that is not considered debt under this definition (e.g., payment on delivery) will not give rise to debt.

4. Debt guarantees. For the purposes of the relevant assessment criteria, the guarantee of a debt arises from any explicit legal obligation of the government to service a debt in the event of nonpayment by the debtor (involving payments in cash or in kind).

5. Debt concessionality. For the purposes of the relevant assessment criteria, a debt is considered concessional if it includes a grant element of at least 35 percent; $^{1}$ the grant element is the difference between the present value (PV) of debt and its nominal value, expressed as a percentage of the nominal value of the debt. The PV of debt at the time of its contracting is calculated by discounting the future stream of payments of debt service due on this debt. ${ }^{2}$ The discount rates used for this purpose are the currency specific commercial interest reference rates (CIRRs), published by OECD. ${ }^{3}$ For debt with a maturity of at least 15 years, the ten-year-average CIRR is used to calculate the PV of debt and, hence, its grant element. For debt with a maturity of less than 15 years, the sixmonth average CIRR is used. The margins for differing repayment periods $(0.75$ percent for repayment periods of less than 15 years, 1 percent for 15 to 19 years, 1.15 percent for 20 to 29 years, and 1.25 percent for 30 years or more) are added to the ten-year and sixmonth CIRR averages.

6. External debt. For the purposes of the relevant assessment criteria, external debt is defined as debt borrowed or serviced in a currency other than the CFA franc. This definition also applies to debt among WAEMU countries.

7. Reporting requirements. The government will report any new external borrowing and its terms to Fund staff as soon as external debt is contracted or guaranteed by the government, but no later than within two weeks of such external debt being contracted or guaranteed.

\section{Quantitative Performance Criteria}

8. Quantitative performance criteria are proposed for June and December 2011 for the overall deficit (commitment basis, including grants) as defined in paragraph 4;

\footnotetext{
${ }^{1}$ The following reference on the IMF website creates a link to a tool that allows for the calculation of the grant element of a broad range of financing packages: http://www.imf.org/external/np/pdr/conc/calculator.

${ }^{2}$ The calculation of concessionality will take into account all aspects of the debt agreement, including maturity, grace period, payment schedule, upfront commissions, and management fees.

${ }^{3}$ For debts in foreign currencies for which the OECD does not calculate a CIRR, calculation of the grant element should be based on the composite CIRR (weighted average) of the currencies in the SDR basket.
} 
contracting or guaranteeing of non-concessional and short-term external debt as specified below in this paragraph; and accumulation of external arrears. Programmed amounts for March and September 2011 are benchmarks. The following performance criteria will be monitored on a continuous basis: (i) the contracting or guaranteeing of new nonconcessional external debt by the government, public enterprises and other official sector entities unless excluded in Tables 1 of the Memorandum of Economic and Financial Policies (MEFP), as well as private debt for which official guarantees have been extended and which, therefore constitute a contingent liability of the government; (ii) the contracting or guaranteeing of new short-term external debt; and (iii) the accumulation of arrears on the external debt service of the government.

\section{A. Overall Deficit Including Grants}

\section{Definition}

9. For the program, the overall deficit including grants is valued on a commitment basis (base engagement). It is the sum of foreign and domestic financing (net) of the government measured from the financing side plus cash basis adjustment. Net foreign financing is the sum of foreign borrowing minus amortization. Net domestic financing is the sum of (i) net bank credit to the government, including both net bank credit to the treasury as defined below and other government claims on and debts to national banking institutions; (ii) unredeemed government bills and bonds held outside national commercial banks; and (iii) privatization receipts. Net bank credit to the treasury is the balance of the treasury's claims and debts vis-à-vis national banking institutions. Treasury claims include the cash holdings of the Burkinabè Treasury, deposits with the central bank, deposits with commercial banks, secured obligations, and government deposits with the postal system (CCP). Treasury debt to the banking system includes funding from the central bank (including statutory advances, consolidated advances, IMF financing, and refinancing of secured obligations), government securities held by the central bank, funding from commercial banks (including government securities held by commercial banks), and CNE (Caisse Nationale d'Épargne Postale)/CCP securitized deposits. Net bank credit to the government is calculated by the Central Bank of West African States (BCEAO), whose figures are recognized as valid for program purposes. The stock of treasury bills and other government debt, as well as net foreign financing, is calculated by the Ministry of Finance. Cash basis adjustment is the sum of (i) expenditure commitments not paid (engagées nonpayées); and (ii) change in treasury deposits.

10. All these items are valued according to the statement of government budgetary execution established monthly in the central government's financial operations table. This is prepared by the Permanent Secretariat for the Monitoring of Financial Policies and Programs (SP-PPF), in collaboration with the other departments of the Ministry of Economy and Finance. 


\section{Adjustment}

11. The overall deficit including grants is adjusted upward by the amount that grants fall short of what is programmed up to a maximum of CFAF 25 billion (see the MEFP Table 1). It will not be adjusted if grants are higher than programmed.

12. The overall deficit including grants will also be adjusted upward by the amount that concessional loans exceed what is programmed up to a maximum of CFAF 15 billion (see the MEFP Table 1).

\section{Reporting deadlines}

13. The Ministry of Economy and Finance will forward data to the IMF on the overall deficit excluding grants within six weeks after the end of each quarter.

\section{B. Nonaccumulation of External Arrears}

\section{Performance criterion}

14. The government's external debt is the stock of debt owed or guaranteed by the government. External arrears are external payments due but not paid on the due date. Under the program, the government undertakes not to accumulate arrears on its external debt, except those arising from government debt being renegotiated with creditors, including non-Paris Club bilateral creditors. Nonaccumulation of external arrears is a performance criterion, to be observed continuously.

\section{Reporting deadlines}

15. Data on outstanding balances, accumulation, and repayment of external arrears will be forwarded within six weeks after the end of each month.

\section{Nonconcessional External Debt Contracted or Guaranteed by the Government}

\section{Performance criterion}

16. The government undertakes not to contract or guarantee any non-concessional external debt beyond the ceiling indicated in the MEFP (Table 1). This performance criterion applies to debt as defined in paragraph 3 and to external debt as defined in paragraph 6 of this TMU; and it uses the definition of debt concessionality as defined in paragraph 5 of the same document. This performance criterion also applies to commitments contracted or guaranteed (including lease-purchase contracts) for which no value have been received. This criterion also applies to the guaranteeing of private sector debt by the government, which consequently constitutes a contingent liability of the government, as defined in section I of this memorandum. In addition, this criterion applies to public enterprises, local governments, and other official entities (including administrative, professional, and scientific and technical public agencies) unless excluded in the MEFP (Table 1). External debt excludes Treasury bills and bonds issued in CFA francs on the WAEMU regional market. This performance criterion is to be observed 
continuously. It is measured on a cumulative basis from the time of approval of the ECF by the Executive Board. No adjuster will be applied to this criterion.

\section{Reporting deadlines}

17. Details on any loan (terms and creditors) to the government or guaranteed by the government must be reported within four weeks of the end of each month. The same requirement applies to guarantees granted by the government.

\section{Government Short-Term External Debt}

18. The definitions in paragraph 11 also apply to this performance criterion. Shortterm external debt is debt with a contractual term of less than one year. Import- and export-related loans, Treasury bills issued in CFA francs on the WAEMU regional market, normal short-term supplier credits, and debt relief operations are not covered by this performance criterion.

\section{Performance criterion}

19. In the context of the program, the government undertakes not to contract or guarantee short-term nonconcessional external debt. The definition of nonconcessional in paragraph 5 applies here. The government also undertakes not to contract or guarantee any short-term external debt without having first determined its concessionality with IMF staff. This performance criterion is to be observed continuously. As of September 30, 2010, the government of Burkina Faso had no short-term external debt.

\section{OTHER QUANTITATIVE INDICATIVE TARGETS}

20. The program also includes indicative targets on total government revenue, poverty-reducing social expenditures, accumulation of domestic payment arrears, and large taxpayer nonfiler rates.

\section{A. Total Government Revenue}

\section{Definition}

21. Total government revenue is valued on a cash basis. It includes all tax and nontax revenue collected by the Directorate General of Taxation, the Directorate General of Customs, the Burkinabè Treasury, and revenue collection units at ministries and institutions. It also includes revenue from treasury checks.

\section{Reporting deadlines}

22. Details on total revenue will be sent to IMF staff by the SP-PPF of the Ministry of

Finance and Budget within six weeks after the end of each month. 


\section{B. Poverty-Reducing Social Expenditures}

\section{Definition}

23. Poverty-reducing social expenditures are defined by the PRSP priority sector programs designed to accelerate the reduction of poverty. They cover all spending categories for the following ministries: Primary Education and Literacy; Health; Social Action and National Solidarity; Promotion of Women; Labor and Social Security; Employment and Youth; Agriculture, Water and Fishing Resources; Animal Resources; and Environment and Living Conditions. They also cover rural roads and HIPC resources (Category 5) for infrastructure spending and HIPC expenditures only for the Justice Ministry and the Ministry of Economy and Development. These expenditures are monitored directly through the budget.

\section{Reporting deadlines}

24. The government will report within six weeks after the end of each month the monthly data on poverty-reducing social expenditures.

\section{Nonaccumulation of Domestic Payment Arrears}

\section{Definition}

25. The government will not accumulate any arrears on domestic government obligations during the program period. This is a benchmark to be observed continuously.

\section{Reporting deadlines}

26. Data on balances, accumulation, and repayment of arrears on domestic government obligations will be reported within four weeks after the end of each month.

\section{Large Taxpayer Nonfiler Rate}

\section{Definition}

27. The large taxpayer nonfiler rate is the ratio of late and nonfilers in the Large Taxpayer Office (LTO) relative to the total number of taxpayers obligated to file in LTO. A late filer is anyone who files a tax return after the deadline. A nonfiler is anyone in the database who did not file taxes. The main tax categories are the VAT (TVA), the corporate income tax (BIC), and the tax on wage income (IUTS). Filing deadlines for the main tax categories are set in the tax code.

\section{Reporting deadlines}

28. The government will report within two weeks after the end of each quarter the total number of late and nonfilers as well as the total number of taxpayers obligated to file in LTO for the main tax categories. 


\section{IV.STRUCTURAL BENCHMARKS}

29. The program incorporates structural benchmarks (see the MEFP Table 2).

\section{AdDitional Program Monitoring InFORMATION}

\section{A. Public Finance}

30. The government will report the following to Fund staff:

- The monthly government flow-of-funds table (TOFE) and the customary appendix tables, to be forwarded within six weeks after the end of each month; if data on actual investment financed by external grants and loans are not available in time, a linear implementation estimate based on the annual projections will be used;

- Complete monthly data on domestic budgetary financing (net bank credit to the government and stock of unredeemed treasury bonds and bills), to be provided within six weeks after the end of each month;

- Quarterly data on implementation of the public investment program, including details on financing sources, to be sent within six weeks after the end of each quarter;

- Quarterly data on external debt stock, external debt service, signing of external loans, and disbursements of external loans, to be sent within six weeks after the end of each quarter;

- Monthly data in the table on the monitoring of poverty-reducing expenditures that will be submitted with the same transmission delay as for the above-defined TOFE table;

- Monthly data on prices and taxation of petroleum products, including (i) prices prevailing during the month; (ii) detailed calculation of the price structure, from the f.o.b.-MED price to the retail price; (iii) volumes purchased and made available for consumption by the petroleum distributor (SONABHY); and (iv) a breakdown of receipts from the taxation of petroleum products - customs duties, tax on petroleum products (TPP), and value-added tax (VAT) — and of subsidies, to be provided within four weeks after the end of each month;

- A monthly statement of the status of accounts with the treasury, classified by major category (administrative services, state enterprises, mixed enterprises, public administrative enterprises, international organizations, private depositors, and others), to be provided within six weeks after the end of each month;

- Quarterly data for the large taxpayer office on (for TVA, BIC, IUTS) the numbers of: register taxpayers, statements received, and reminder letters sent to late and non filers; and 
- These quarterly statistics are to be provided within two weeks after the end of each quarter. Similarly, quarterly data on the following are to be sent within two weeks of the end of the quarter: total number of customs statements, number of statements selected by channel, and number of statements by channel subject to non-standard treatment.

\section{B. Monetary Sector}

31. The government will provide the following information within six weeks after the end of each month:

○ The consolidated balance sheet of monetary institutions;

- Provisional data on the monetary survey provided six weeks after the end of each month (with final data provided ten weeks after the end of each month);

○ Borrowing and lending interest rates; and

- Customary banking supervision indicators for bank and nonbank financial institutions, if necessary.

\section{Balance of Payments}

32. The government will report the following to Fund staff:

- Any revision of balance of payments data (including services, private transfers, official transfers, and capital transactions), as they occur;

- Foreign trade statistics compiled by the National Statistics Institute, within three months after the end of the month concerned; and

- Preliminary annual balance of payments data within nine months after the end of the year concerned.

\section{Real Sector}

33. The government will report the following to Fund staff:

- Disaggregated monthly consumer price indices, within two weeks after the end of each month;

- Provisional national accounts; and

- Any revision of the national accounts.

\section{E. Structural Reforms and Other Data}

34. The government will also report the following: 
○ Any study or official report on Burkina Faso's economy, within two weeks after its publication and

- Any decision, order, law, decree, ordinance, or circular that has economic or financial implications as soon as it is published or at the latest when it enters into force. 


\section{APPENDiX II-EXChange RATE ASSESSMENT ${ }^{1}$}

The exchange rate assessment suggests that Burkina Faso's real effective exchange rate was broadly in line with economic fundamentals with a misalignment in the range of -0.1 to 8.4 percent. REERs analysis based on price indices that accounts for producers' costs and profitability shows mixed results and volatility over the last decade.

\section{Effective Exchange Rate Developments}

1. The exchange rate has fluctuated in recent years, reflecting developments in the euro, to which the CFA Franc is pegged. ${ }^{2}$ In 2007-2009, the nominal effective exchange rate (NEER) and the real effective exchange rate (REER) appreciated by about 9.3 percent and 8.3 percent, respectively, reflecting the strengthening of the euro against the U.S. dollar. Because the euro weakened somewhat in 2010, and inflation declined, the REER depreciated by 8.4 percent (Text Figure 1).

2. Recent exchange rate developments in Burkina Faso were similar to those in other WAEMU countries. Except for Mali and Niger, other WAEMU countries experienced a REER appreciation in 2005-08, which was subsequently reversed in 2009 and 2010 (Text Figure 2).

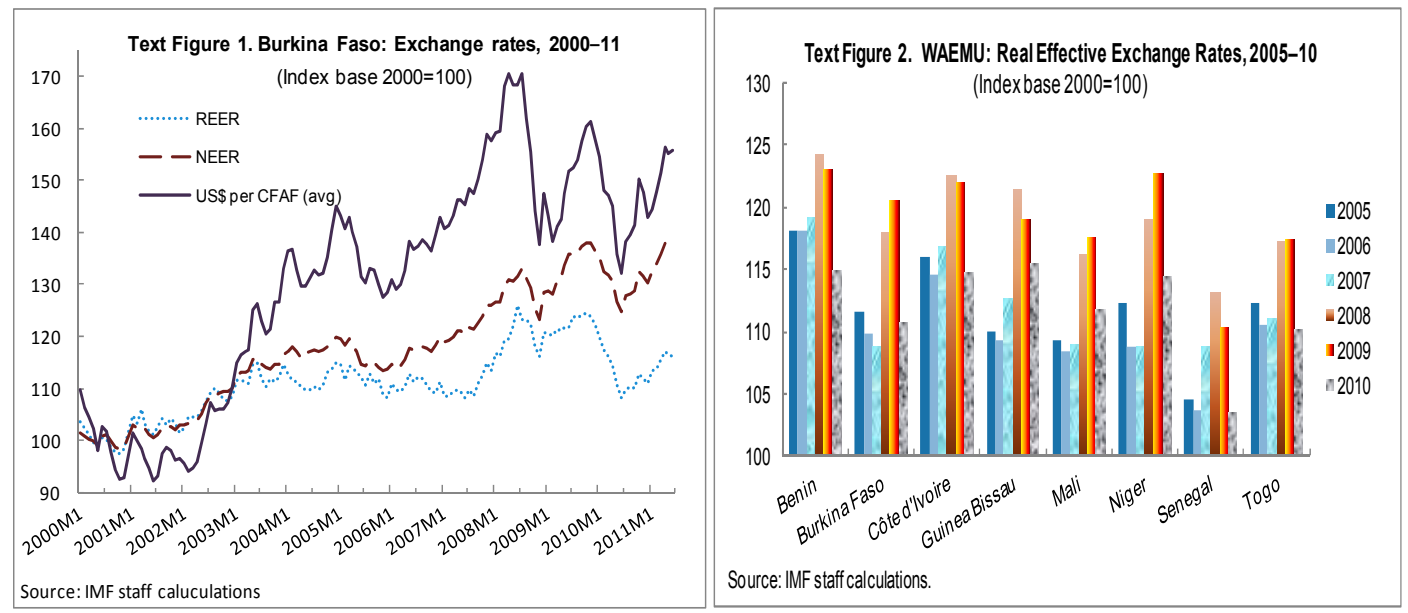

\footnotetext{
${ }^{1}$ Prepared by Mame Astou Diouf with contributions from Anita Anoevna Niangoran and David Corvino.

${ }^{2}$ Movements in the Cedi, the currency of Ghana-Burkina Faso's main trading partner with 20 percent of its trade flows - is closely linked to those in the U.S. dollar. Moreover, the United States is Burkina Faso's fifth trading partner with 7 percent of the country's trade flows.
} 


\section{Exchange Rate Assessment with CGER Methodologies ${ }^{3}$}

\section{A. Macroeconomic Balance Approach}

3. The macroeconomic approach assesses external sustainability based on a current account norm consistent with medium-term economic fundamentals. It suggests an overvaluation of 1.3 percent. Using this approach, the model estimates the exchange rate adjustment needed to close the gap between the current account (CA) norm, defined as the estimated equilibrium $\mathrm{CA}$, and the $\mathrm{CA}$ balance projected over the medium term. The results show that the $\mathrm{CA} \mathrm{norm}{ }^{4}$ is narrower than the projected CA deficit for 2015 by about $1 / 2$ percent of GDP. Hence, accounting for the elasticity ${ }^{5}$ of the CA to the REER, a REER depreciation of 1.3 percent would be needed to restore the balance (Table 1).

\begin{tabular}{|c|c|c|c|c|c|}
\hline & \multicolumn{3}{|c|}{ Current account/GDP } & \multirow{2}{*}{$\begin{array}{l}\text { CAREER } \\
\text { elasticity }\end{array}$} & \multirow{2}{*}{$\begin{array}{c}\text { REER } \\
\text { misalignment }^{1}\end{array}$} \\
\hline & Norm & Underlying & Gap & & \\
\hline Macroeconomic balance & -5.22 & -5.74 & -0.53 & -0.42 & 1.25 \\
\hline External sustainability & -2.23 & -5.74 & -3.52 & -0.42 & 8.37 \\
\hline Equilibrium real ER for 2009 & $\ldots$ & $\ldots$ & $\ldots$ & $\ldots$ & 3.2 \\
\hline Equilibrium real ER for 2010 & $\ldots$ & $\ldots$ & $\ldots$ & $\ldots$ & -0.1 \\
\hline
\end{tabular}

\section{B. The External Sustainability Approach}

4. The external sustainability (ES) approach assesses external stability using the current account balance that would stabilize net foreign assets at a benchmark level. This approach comes to an overvaluation of 8.4 percent. Under the ES approach, the model estimates the difference between the medium-term CA balance and the CA balance that would stabilize the country's net foreign assets (NFA) at a benchmark level. Simulation results show that the CA deficit projected for 2015 is larger than the NFA-

\footnotetext{
${ }^{3}$ The exchange rate is assessed using the three approaches advocated by the IMF Consultative Group on Exchange Rate Issues (CGER): the Macroeconomic Balance approach; the External Sustainability Approach, and the Equilibrium Real Effective Exchange Rate.

${ }^{4}$ To estimate the CA norm, we use the model and coefficients from Lee and others (2008). Results show that the main contributors to Burkina Faso's CA norm are the lagged value of current account deficit (with a contribution to the norm of -1.8 percent), the medium-term oil balance (-1.42 percent), and the mediumterm income differential ( -1.9 percent).

${ }^{5}$ Estimated by Tokarick (2010).
} 
stabilizing CA deficit by 3.5 percent of GDP, leading to an estimated overvaluation of the REER of 8.4 percent $^{6}$ (Table 1).

\section{Equilibrium Real Exchange Rate Approach}

\section{The reduced-form equilibrium real} exchange rate approach (ERER) calculates the difference between the equilibrium exchange rate and the actual exchange rate. Comparing the paths of the REER and the estimated long-term equilibrium REER shows that the CFAF was overvalued in the 1980s, and then became undervalued from 1994 - when it

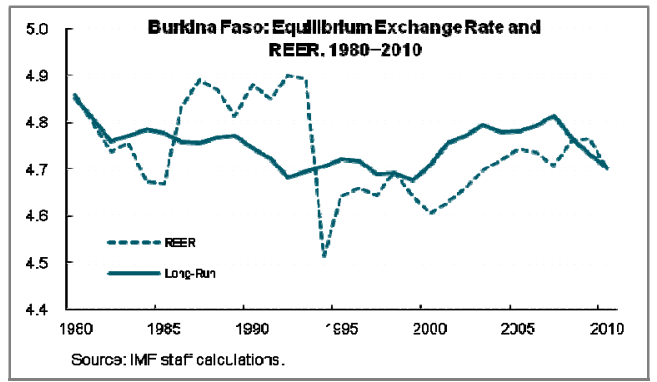
was devaluated by 50 percent compared to the French Franc. The figure above shows that the REER remained undervalued until 2009.

\section{The ERER approach suggests an overvaluation of about 3.2 percent in 2009} and a moderate undervaluation in 2010. Estimates indicate that in 2009, the ERER was 113.6 while the average REER stood at 117.3, leading to an estimated overvaluation of about 3.2 percent. The depreciation that took place from mid-2010 to mid-2011 brought the REER near equilibrium in 2010 with an ERER at 110.17 compared with an average REER of 110.06; hence a slight undervaluation of 0.1 percent. $^{7}$

\footnotetext{
${ }^{6}$ The note uses Burkina Faso's 2009 NFA from the updated and extended version of the Lane and MilesiFerretti (2007) dataset provided by the IMF research department.

${ }^{7}$ The ERER is estimated using Burkina Faso's specific model based on the country's productivity proxied by its real GDP per capita relative to trading partners, terms of trade, government consumption, and the country's openness proxied by the ratio of trade flows to GDP. The assessment at end-2009 shows an overvaluation whereas the one at end-2010 shows an undervaluation because the REER depreciated in 2010 more than the ERER (7.2 percentage points vs. 3.4). The main positive contributor to the ERER is terms of trade.
} 


\section{Assessment Using REERs Based on Other Price Indices}

\section{The REER assessment using price indices other than the consumer price} index, confirms the CGER ${ }^{8}$-based methodology results. This method uses price indices better suited in capturing some aspects of producers' profitability than the consumer price index (CPI), ${ }^{9}$ notably costs structure and profit margins: unit labor cost (ULC), labor productivity (LP), and internal terms of trade (TT). The results point to an appreciation of the exchange rate in recent years. In addition, producers' competitiveness was eroded by an increase in unit labor costs and terms of trade, as well as slow improvement in labor productivity in Burkina Faso compared with its trading partners (Figure 1).

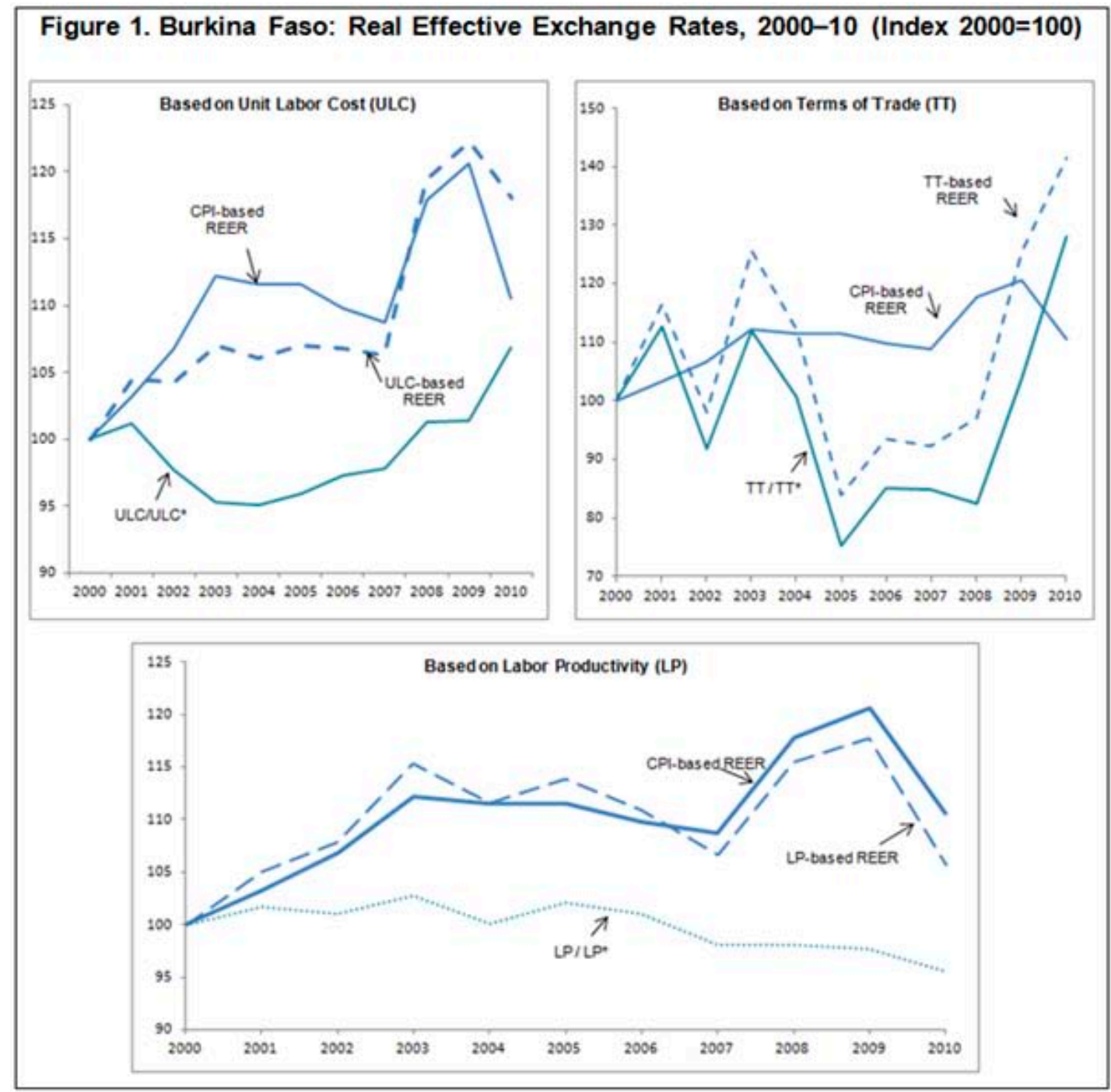

\footnotetext{
${ }^{8}$ The Consultative Group on Exchange Rate issues (IMF).

${ }^{9}$ The CGER-based assessment presented above makes use of a CPI-based REER, which is the most popular REER.
} 
8. During the last five years, Burkina Faso's price competitiveness and labor productivity remained broadly in line with the WAEMU standards. While unit labor costs, terms of trade, and the GDP deflator increased in all WAEMU countries, for Burkina Faso, these indicators were lower than in most countries in the region. In addition, Burkina Faso had the second highest labor productivity of the region (Figure 2). ${ }^{10}$

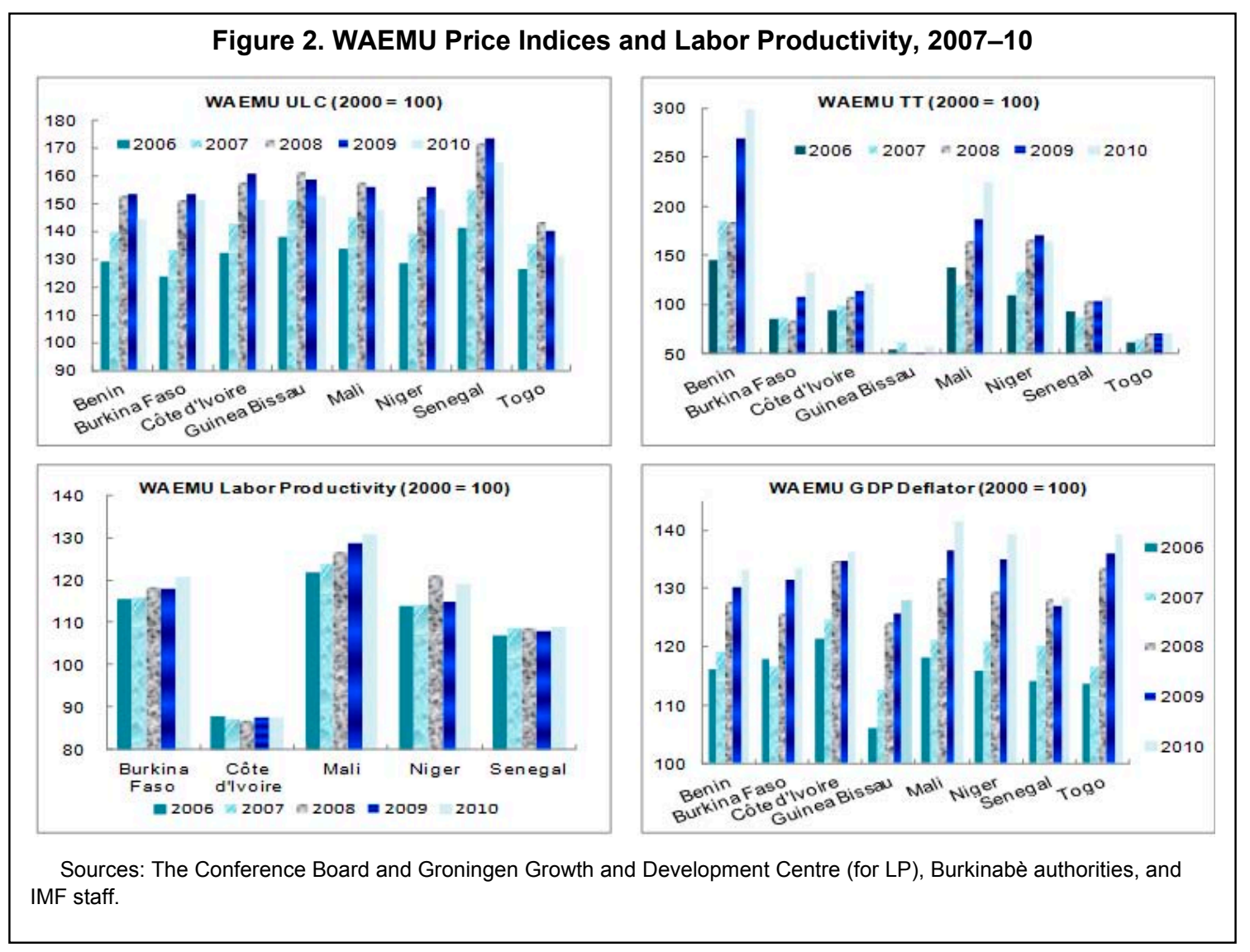

\section{Non-Price Competitiveness}

9. Despite the abovementioned results, Burkina Faso needs to further structural reforms to address non-price competitiveness impediments to private sector development. With its currency pegged to the euro and monetary policy conducted by the regional central bank, continued efforts are needed to reduce transaction costs and improve the business environment further. Although there has been progress on some of the World Bank Doing Business indicators, ${ }^{11}$ Burkina Faso was ranked 134 out of 139 in the 2010-11 Global Competitiveness Index. Inadequate access to finance, poor

\footnotetext{
${ }^{10}$ Excluding Benin, Togo, and Guinea-Bissau for which data are not available.

${ }^{11}$ Burkina Faso' s ranking improved from 154 under the 2010 Doing Business indicators to 150 under the 2012 indicators (out of 183 countries). In the 2012 survey, the country ranked $24^{\text {th }}$ in Sub-Saharan Africa and second in WAEMU after Mali (which ranked $22^{\text {nd }}$ in Sub-Saharan Africa).
} 
infrastructure, an unskilled workforce, weak regulation, and the country's limited absorptive capacity are among the main factors identified as hindering private sector development. Similarly, the country's scores under the World Governance Indicators generally fall below the $50^{\text {th }}$ percentile, though higher than the WAEMU countries' scores and the Sub-Saharan Africa average scores. ${ }^{12}$

\section{Conclusion}

10. The ER assessment using CGER methodologies suggests that the exchange rate is broadly in line with fundamentals for Burkina Faso, with a misalignment in the range of $-\mathbf{0 . 1}$ to 8.4 percent. REER assessment using other price indices indicates that competitiveness has been eroded by the nominal appreciation of the NEER, an increase in Burkina Faso's relative unit labor costs and terms of trade, and a slower improvement in labor productivity compared to trading partners. REERs developments based on indices capturing producer profitability and non-price competitiveness indicators point to the need for continued structural reforms to support private sector development.

\footnotetext{
${ }^{12}$ Compared to a range of $[-0.25,+0.25]$, Burkina Faso scored -0.24 for voice and accountability, -0.11 for political stability, -0.58 for government effectiveness, -0.11 for regulatory quality,-.21 for rule of law, and 0.37 for corruption control in the 2010 World Governance Indicators.
} 


\section{References}

International Monetary Fund, 2010, "Updated and Extended Version of the Lane and Milesi-Ferretti (2007) Dataset”, Research Department, Washington D.C.

IMF, 2008, SPR note: "How to Apply CGER Methodologies to Non-CGER Countries: A Guide for Desk Economists”, Washington D.C.

Lee, J., G.M. Milesi-Ferretti, J. Ostry, A. Prati, L.A. Ricci, 2008, “Exchange Rate Assessments: CGER Methodologies”, IMF Occasional Paper No. 261, Washington D.C.

Lane, P.R., and G.M, Milesi-Ferretti, “The External Wealth of Nations Mark II: Revised and Extended Estimates of Foreign Assets and Liabilities, 1970-2004”, Journal of International Economics 73, November 2007, pp. 223-250.

Tokarick S., 2010, “A Method for Calculating Export Supply and Import Demand Elasticities” IMF Working Paper 10/180, Washington D.C. 


\section{APPENDIX III-PUbLIC INVESTMENT SCALING UP, GROWTH AND DEBT SUSTAINABILITY IN BURKINA FASO ${ }^{1}$}

\section{Introduction}

1. This note examines the link between public investment, growth and debt sustainability for the Burkina Faso economy. It uses an open-economy Dynamic General Equilibrium (DGE) model developed by Buffie and others (2011) to simulate the macroeconomic implications of investment scaling-up, based on the assumption in the authorities' new PRSP.

2. Simulation results from the model are consistent with results from the 2011 DSA analysis based on the IMF/World Bank Low Income Debt Sustainability

Framework. The note discusses them under two external financing options, and the fiscal adjustment (tax policy) needed to safeguard long-term debt sustainability. The discussion takes into account Burkina Faso's particular circumstances, namely the country's membership to a customs and monetary union - which limits the scope for unilateral adjustment in the Value-Added Tax (VAT) rate; the high risk of debt distress; and the economy's vulnerability to exogenous shocks.

\section{Calibration}

3. The model is calibrated to match salient features of the Burkinabe economy. While all steady state ratios - based on recent National Accounts and fiscal data - are specific to Burkina Faso, "deep" parameters are calibrated to the average LIC as in Buffie and others (2011) where relevant information was not available for Burkina Faso.

4. The efficiency of public investment drives the model's quantitative results. To account for various weaknesses in the investment process we assume that 70 cents out of each dollar spent in public investment increases the stock of productive infrastructure. This parameter's value is also slightly above the 60 cents per dollar benchmark assumed in Buffie and others (2011), reflecting Burkina Faso's relatively good score in the recent "Public Investment Management Index" (PMI) developed by Dabla-Norris and others (2011), which ranked Burkina Faso in the fourth quartile of the PMI distribution in a sample of 71 developing countries.

5. Public investment is assumed to yield an annual gross return of 25 percent. This value appears appropriate because it applies to effective infrastructure, thus netting out inefficiencies in the capital accumulation process. The assumed return on infrastructure is in line with the relevant literature (see, e.g., Dalgaard and Hansen (2005), and Briceno-Garmendia (2010), among others).

\footnotetext{
${ }^{1}$ Prepared by Constant Lonkeng Ngouana, and Malangu Kabedi-Mbuyi (All AFR). This note has benefited from valuable contributions from the Burkina Faso team, and from Felipe Zanna and Salifou Issoufou (both RES).
} 


\section{Simulation Results and Policy Implications}

\section{Combining concessional borrowing with immediate and unlimited fiscal} adjustment appears compatible with long-term debt sustainability, but requires a drastic change in tax policy. This scenario is based on the investment scaling-up contemplated in the authorities' new PRSP, which includes a doubling of the public investment budget to US\$2.2 billion over a 5-year period. The results indicate that the long-run effects of investment scaling-up are positive. In particular, economic growth increases significantly, particularly in the medium-term, benefitting from higher and efficient public investment and increased private sector investment; and external debt declines to about 20 percent of GDP in the long-term, after an initial increase at the beginning of the period. In the fiscal area, however, taking as given the projected path of official grants ${ }^{2}$, the adjustment needed to supplement concessional loans to cover scaledup investment leads to an increase in the consumption tax rate of more than 10 percentage points in five years, also reflecting the assumed rising cost of infrastructure (Figure 1). For Burkina Faso, this implies that the Value-added Tax (VAT) rate would rise to almost 30 percent, which is neither feasible nor desirable from the macroeconomic viewpoint.

\section{Additional concessional borrowing with delayed and limited fiscal} adjustment leads to an unsustainable level of public. To correct for the abovementioned results on fiscal adjustment, the model was simulated on the assumption that the VAT rate remains unchanged for the first five years, and is subsequently raised by about 2 percentage points. Under this scenario, additional concessional borrowing is needed to cover the same level of scaled-up public investment as in the baseline scenario. Simulation results point to a positive macroeconomic impact similar to the baseline scenario, with less pronounced negative impact in private investment and consumption in the initial years - as the tax rate does not rise immediately. However, the additional borrowing raises external public debt to almost 60 percent of GDP in the medium term (Figure 2). Although the ratio declines subsequently, it remains elevated, and raises concerns in view of the high risk of debt distress facing Burkina Faso under current policies. The impact of the debt profile is even stronger with a staggered increase in the VAT

\section{A staggered increase in the VAT rate lessens the impact of the fiscal} adjustment, and but deteriorate the long-term debt profile. Simulation results indicate that a stagger increase in the VAT rate could help achieve a smoother fiscal adjustment in the medium term. However, if the scaled-up investment is financed with the additional revenue, and borrowing on commercial terms, the stock of external public debt rises to unsustainable levels in the medium to long-term, reaching some 80 percent of GDP after a 30-year period (up from less than 20 percent of GDP at the beginning of the simulation period). As shown in empirical studies, such a build-up of external debt may hamper long-term growth prospects.

\footnotetext{
${ }^{2}$ Based on the macroeconomic framework under the ECF-supported program.
} 
FiguRE 1. BURKINA FASO-SCALING UP INVESTMENT FINANCED WITH CONCESSIONAL LOANS AND UNLIMITED FisCAL ADJUSTMENT
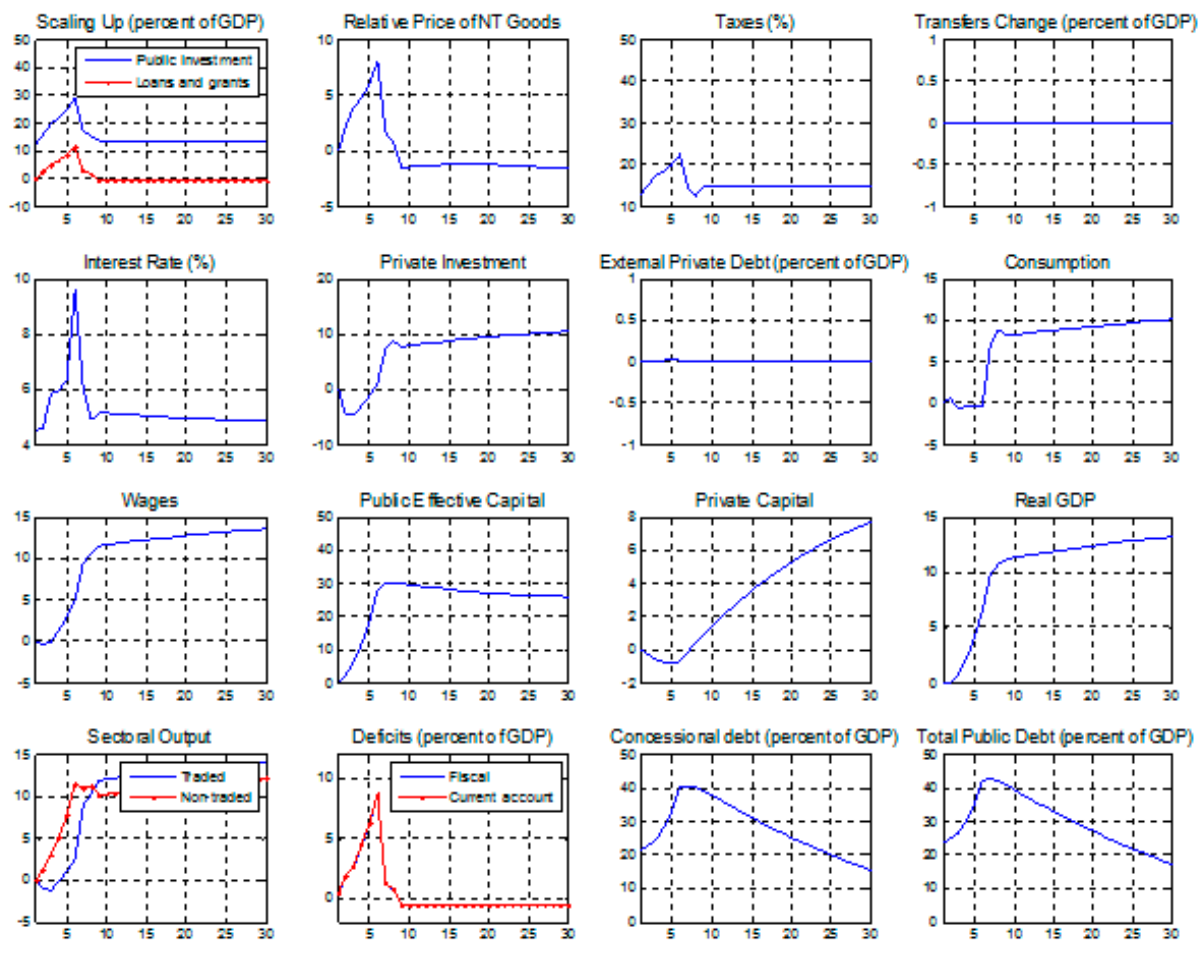

Defcits (percento fGDP)

Concessio ral debt (percent of GDP)

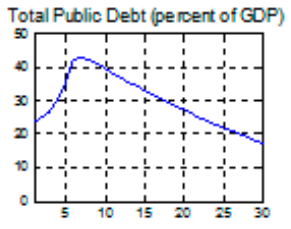

FiguRE 2. BURKINA FASO-SCALED-UP INVESTMENT WITH HIGHER CONCESSIONAL LOANS AND LIMITED FISCAL ADJUSTMENT
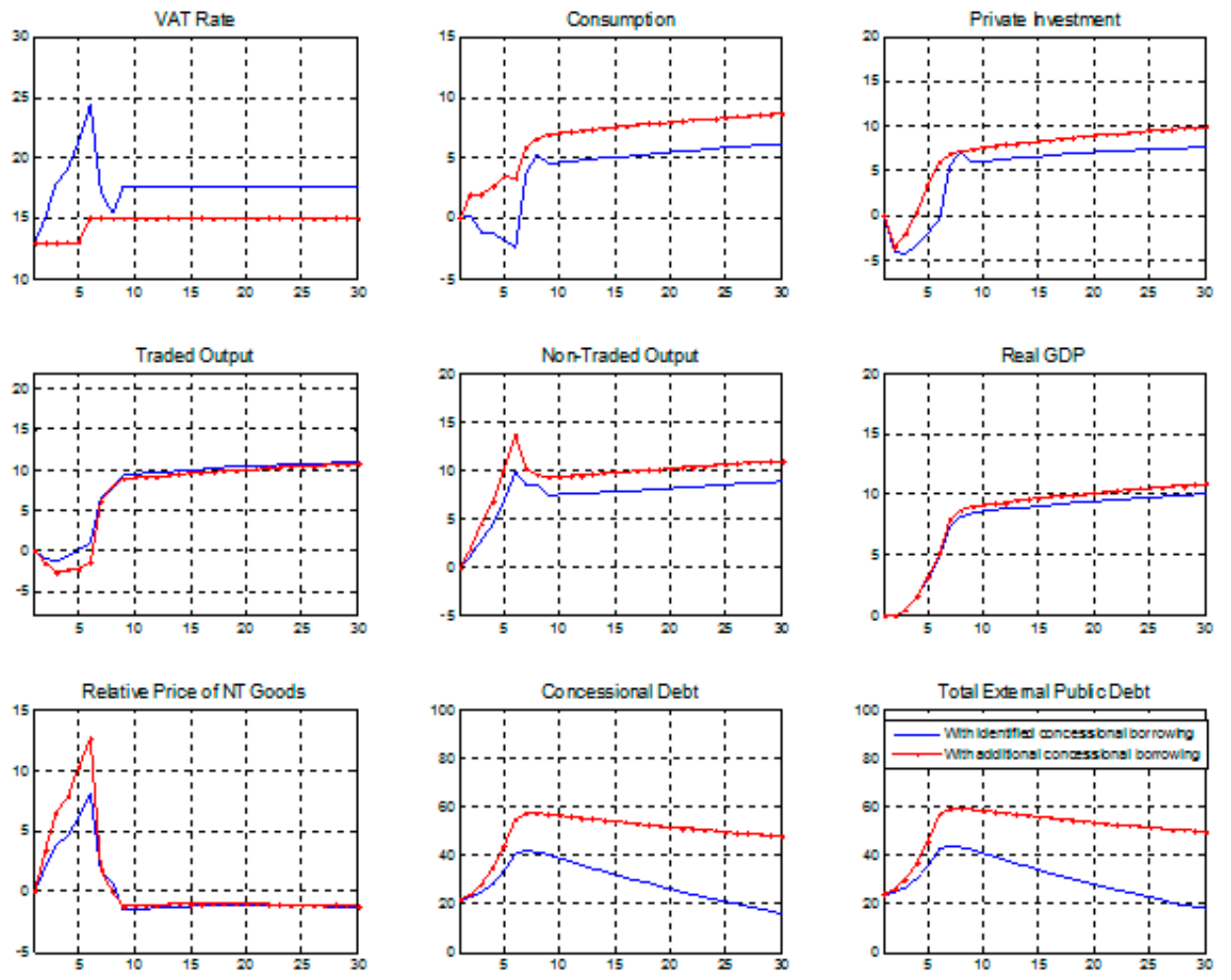
9. Access to nonconcessional borrowing to complement concessional financing of scaled-up investment under the new PRSP seems incompatible with long-term debt sustainability. Under this scenario (Figure 3), commercial loans are assumed to accrue a nominal interest rate of 9.9 percent, based on available estimates for Burkina Faso in Gueye and Sy (2010). Imposing a 20 percent cap on the VAT to smooth the fiscal adjustment, simulation results show that, compared with the baseline scenario, there is a new stock of commercial debt reaching almost 10 percent of GDP after five years and the total stock of public debt rises above 50 percent of GDP before returning to historical levels. The impact on growth is, however, similar to the baseline scenario, while access to commercial borrowing increases external debt obligations, which may prove challenging for Burkina Faso considering the country's narrow export base and vulnerability to terms of trade shocks.

\section{FiguRE 3. BURKINA FASO-SCALED-UP INVESTMENT: CONCESSIONAL BORROWING IS COMPLEMENTED WITH COMMERCIAL LOANS AND LIMITED FISCAL AdJUSTMENT}
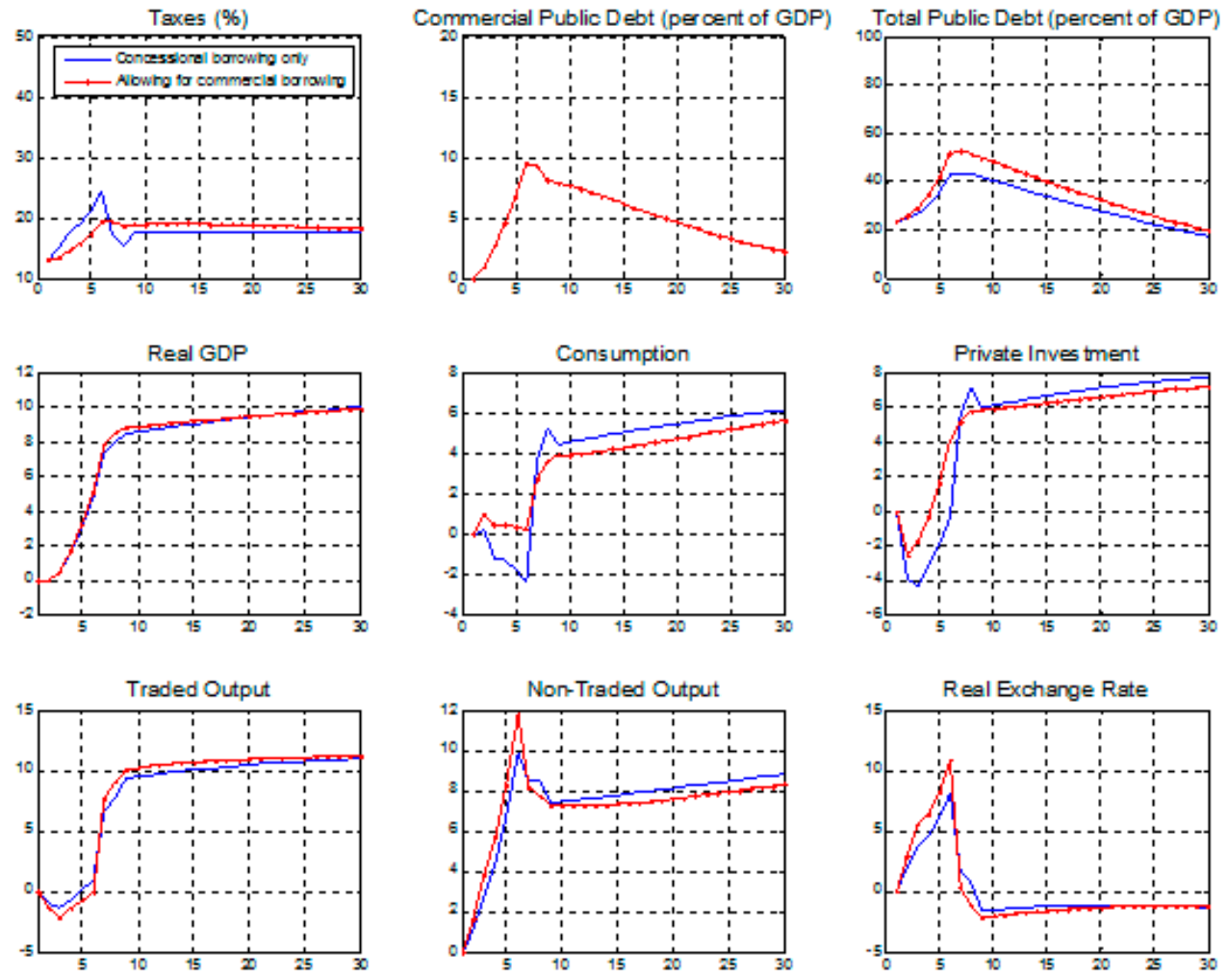

10. Scaling up investment at a modest and continued pace, while improving collection of user fees for infrastructure services, may support debt sustainability and fiscal objectives. Simulation results with public investment scaling-up assumptions under the ECF-supported program suggest that, while the long-term impact of growth is somewhat lower than in scenarios based on the investment scaling-up under the new PRSP, the additional concessional borrowing is compatible with long-term debt sustainability. However, the required fiscal adjustment remains strong, although less 
drastic than in the baseline scenario. Simulations show that a staggered increase in the VAT rate could correct for this effect and provide a smoother fiscal adjustment path. Hence, financing modest increases in public investment through additional revenueunder a staggered tax structure - and concessional borrowing could help contain the impact of the fiscal adjustment and support long-term debt sustainability (Figure 4). Simulations also show that an increase in user fees collection from the current 40 percent in Burkina Faso to about 80 percent would reduce the fiscal adjustment needed to safeguard debt sustainability by about a percentage point.

\section{FigURE 4. BURKINA FASO-MODERATE INVESTMENT SCALING-UP WITH CONCESSIONAL BORROWING AND A STAGgered TAX ADJUSTMENT}
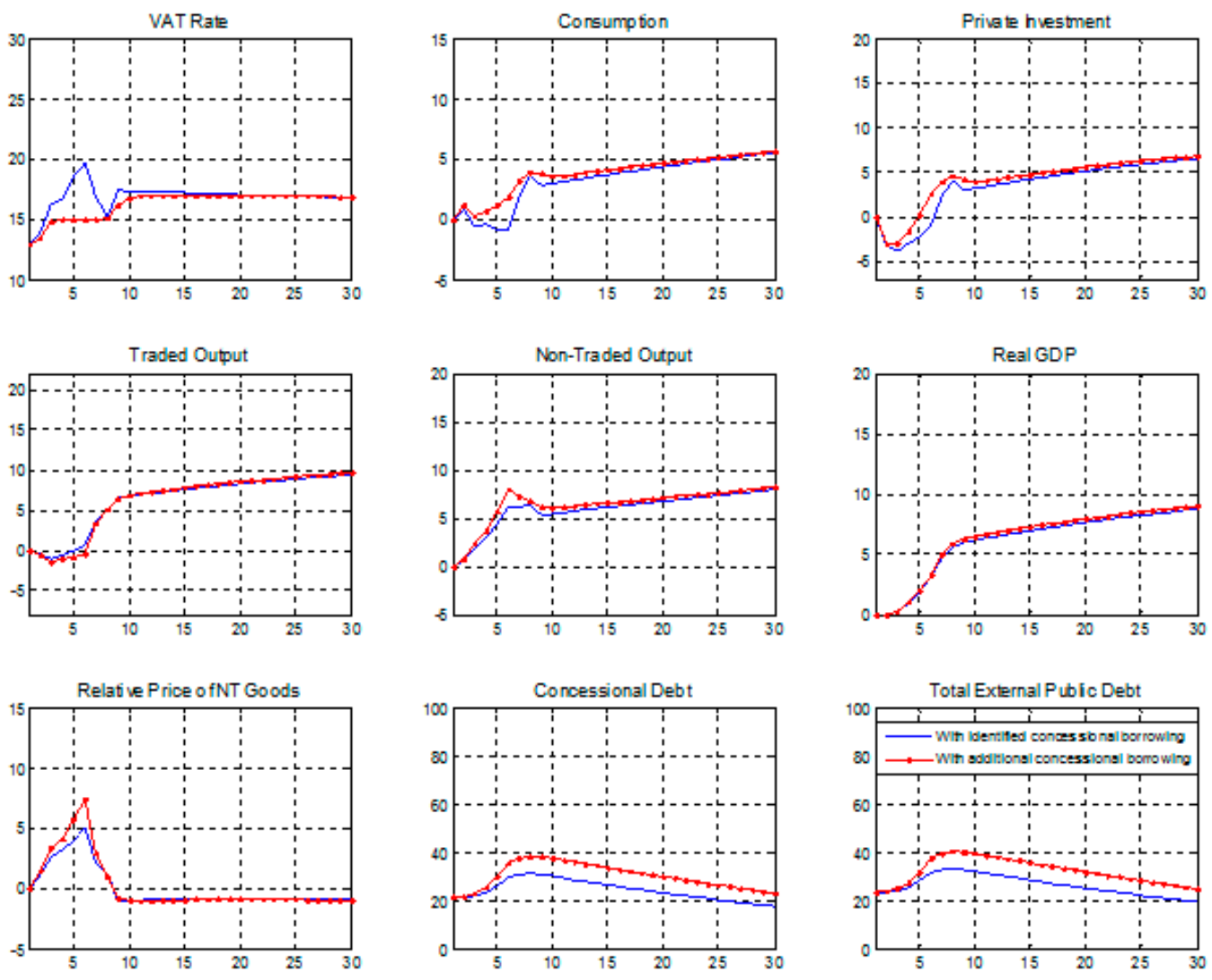

\section{Caveats}

11. The model in buffie and others (2011) is an interesting tool for assessing the impact of scaled-up public investment on growth and on the implications of financing options on debt and fiscal sustainability. Results from the simulations can inform policy decisions on the speed and magnitude of scaled-up investment and implications for financing options, and the needed fiscal adjustment. It is worth noting, however, that as is the case with any such exercise, the results depend on the assumptions. 
Nevertheless, the main policy conclusions appear quite robust to reasonable changes in parameter values.

\section{Conclusion and the Authorities' Views}

\section{Despite a strong long-term macroeconomic impact, scaling-up public} investment may have adverse implications for debt sustainability and require a drastic short-term fiscal adjustment. Results from the application of a DGE model to Burkina Faso's economy show that, under certain conditions, scaling-up investment to levels envisioned in the authorities' new PRSP would raise economic growth substantially in the medium to long-term, boost private investment, and increase consumption. The results also highlight that the choice of financing options for the scaled-up investment should be guided by their implications for long-term debt sustainability, and the resultant fiscal adjustment. In particular, simulation results suggest that scaling-up public investment with insufficient fiscal adjustment may lead to unsustainable levels of external public debt, which, as show in empirical studies, may crowd out private sector investment and hamper long-term growth prospects. Similarly, unlimited fiscal adjustment to finance higher investment may have undesirable macroeconomic effects. Taking into account Burkina Faso's particular circumstances, the results seem to indicate that a better macroeconomic outcome would be achieved if the investment scaling-up is moderate, and financed with higher grants and concessional loans, as well as increased government revenue. The latter could be achieved through a staggered increase in the VAT rate and enhanced collection of user fees on infrastructure services.

\section{The authorities welcomed the analysis and broadly agreed with the policy}

recommendations. They found that the financing option with higher grants and concessional loans was consistent with their approach for financing the new PRSP. In this vein, they expressed interest in using the model's results for the upcoming donors' conference scheduled for early 2012. In the discussion, they found that under all simulation scenarios, the tax adjustment was neither realistic nor feasible because of Burkina Faso's obligations on VAT harmonization as a member of a monetary and customs union. They concurred with staff, however, that it was important to raise revenue to create fiscal space for higher investment, regardless of the policy instrument used to this effect. 


\section{Selected References}

Berg, A., J. Gottschalk, R. Portillo, and F. Zanna (2010), "The Macroeconomics of Medium-Term Aid Scaling-Up Scenarios,” IMF Working Paper WP/10/160, Washington, D.C.

Briceño-Garmendia, C., K. Smits, and V. Foster, 2008, "Financing Public Infrastructure in Sub-Saharan Africa: Patterns and Emerging Issues.” AICD Background Paper 15, World Bank.

Buffie, E.; Berg, A.; Patillo, C.; Portillo, R.; and Zanna, L. F. (2011) "Public Investment, Growth and Debt Sustainability: Putting Together the Pieces", IMF, mimeo, March.

Dabla-Norris, E., Brumby, J., Kyobe, A., Mills, Z. and Papageorgiou, C. (2011) "Investing in Public Investment: An Index of Public Investment Efficiency" IMF Working Paper WP/11/37, February, Washington, DC.

Diouf, A. and C., Lonkeng (2011), “The Macroeconomics of Scaling-Up Aid: The Case of Burkina Faso", IMF, mimeo.

Gueye, C., A. Sy, (2010), "Beyond Aid: How Much Should African Countries Pay to Borrow?” IMF Working Paper WP/10/140, June, Washington, DC.

IMF Country Report No. 11/240, Appendix III: "Linking Public Investment, Growth and Debt Sustainability in Togo", August, Washington, DC. 


\title{
INTERNATIONAL DEVELOPMENT ASSOCIATION AND INTERNATIONAL MONETARY FUND
}

\author{
BURKINA FASO
}

\section{Joint World Bank/IMF Debt Sustainability Analysis}

\author{
Prepared by the staffs of the International Monetary Fund \\ And the International Development Association
}
Approved by Michael Atingi-Ego and Thomas Dorsey (IMF) and Jeffrey D. Lewis and Marcelo Giugale (IDA)

December 8, 2011

The results of the Debt Sustainability Analysis (DSA) are similar to those of the previous $D S A$. Burkina Faso's risk of debt distress is high, because the present value (PV) of debtto-exports ratio is projected to breach its policy-dependent indicative threshold under the baseline scenario and under the stress tests. ${ }^{1}$ However, the breach is projected to occur about 10 years later than in the previous DSA, reflecting better exports prospects over the period. Other debt burden indicators remain below their policy-dependent indicative thresholds under the baseline and stress tests scenarios. In the context of the new PRSP adopted in late 2010, Burkina Faso plans to scale up investment, particularly in infrastructure, to accelerate growth and reduce poverty. The DSA results indicate that financing needs for higher public investment would have to be met mostly with grants and concessional loans to support long-term debt sustainability.

\section{INTRODUCTION}

\section{Burkina Faso's stock of debt comprises public and publicly guaranteed} external debt and domestic debt. At end-2010, external debt amounted to 23.9 percent of GDP with some 80 percent owed to multilateral creditors (Figure 1) and about a third

\footnotetext{
${ }^{1}$ Under the LIC DSF, it is expected that better policies and stronger institutions help countries manage higher levels of debt. Hence, the thresholds for the DSA are policy-dependent and determined based on the World Bank's Country Policy and Institutions Assessment (CPIA) classification. Based on the average CPIA score in 2008-10, Burkina Faso is ranked as a "medium performer". The relevant indicative thresholds for countries in this category are: 40 percent for the present value (PV) of debt-to-GDP ratio; 150 percent for the PV of debt-to-exports ratio; 250 percent for the PV of debt-to-revenue ratio; 20 percent for the PV of debt service-to-exports ratio; and 30 percent for the PV of debt service-to-revenue ratio.
} 
denominated in Euro, which mitigates the impact of exchange rate fluctuations. ${ }^{2}$ Government bonds (Text Table 1) dominate the domestic debt.

2. External debt policy has remained prudent. Burkina Faso has systematically sought grants and concessional loans to cover financing needs. Hence, under the Fund-supported program, the 35 percent grant element requirement for public and publicly-guaranteed external debt is strictly enforced, and investment projects are consistently analyzed by a National Public Debt Committee before loan negotiations are initiated. The DSA assumes that during 2017-31, the structure of Burkina Faso's external debt would not change (see Figure 1), and therefore, the average grant element would remains above 35 percent.

Text Figure 1. Burkina Faso-External Debt Composition by Creditor, 2010

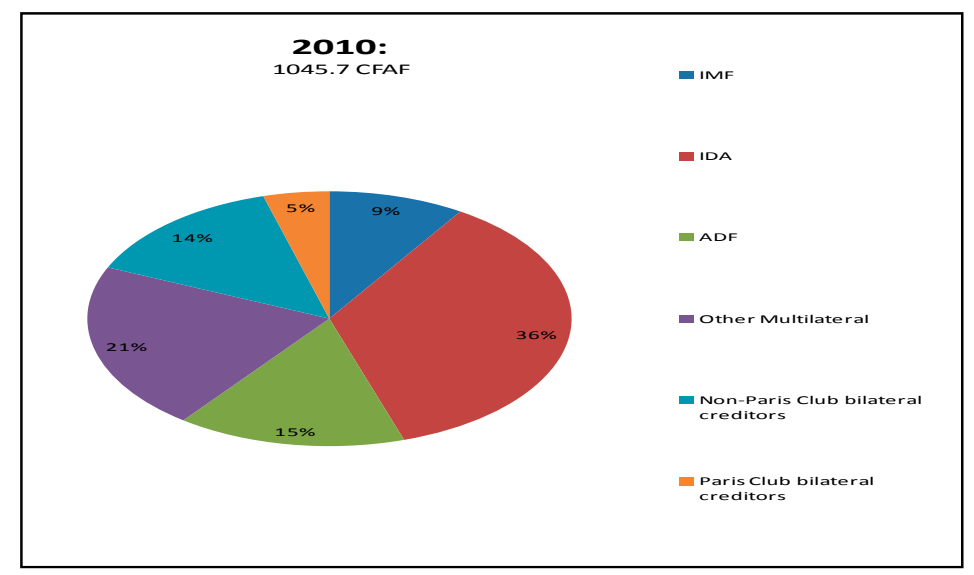

\footnotetext{
${ }^{2}$ Burkina Faso's currency, the CFA Franc which is common to 6 other members of the West African
} Economic and Monetary Union, is pegged to the Euro at a fixed exchange rate. 


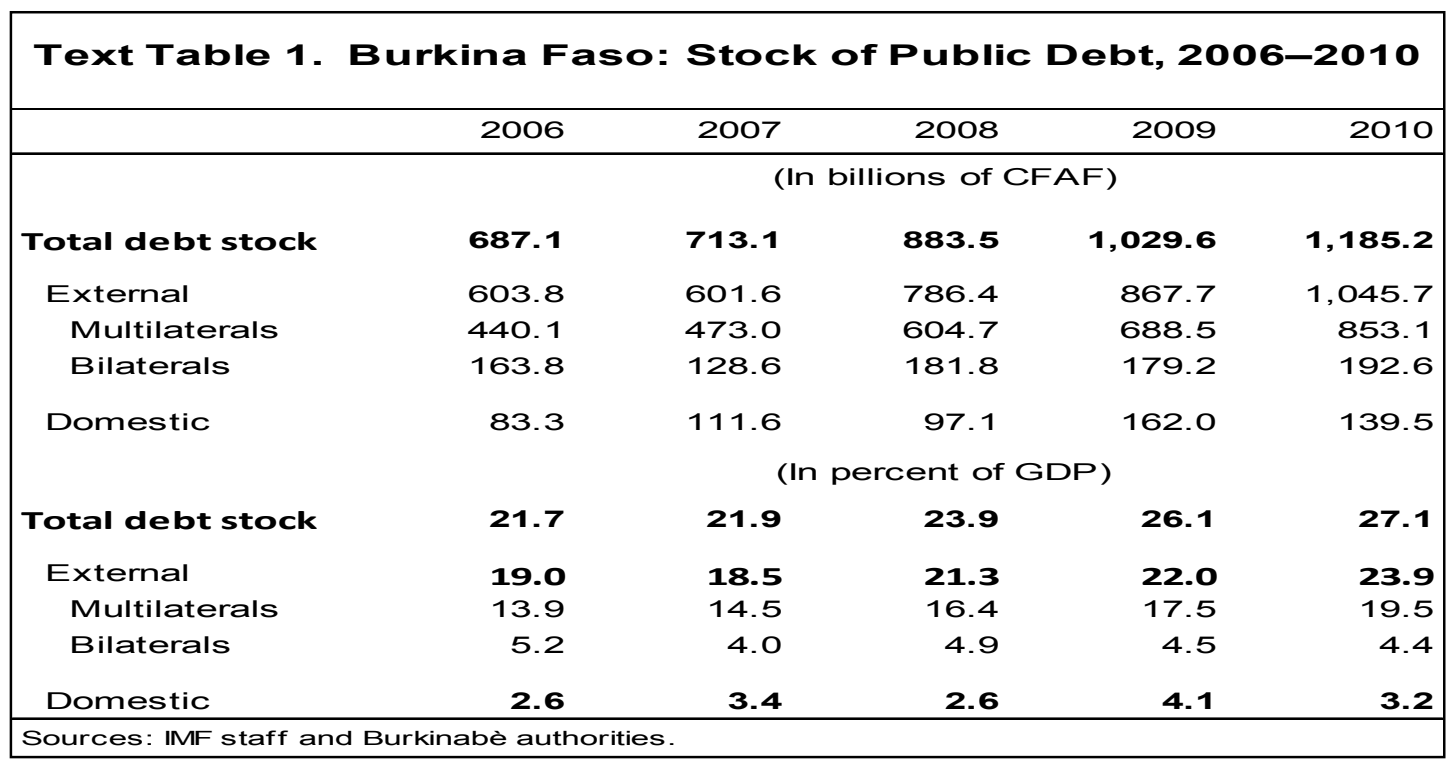

\section{This DSA is carried out with a macroeconomic outlook reflecting the} expected improvement in economic prospects over the medium to long term (Box 1 , Table 1). The outlook underpinning the DSA accounts for the impact of the projected increase in public investment, particularly in infrastructure to achieve growth and poverty reduction objectives outlined in the authorities' new PRSP adopted in December 2010. The outlook reflects also the projected expansion in the mining sector, through higher gold production and the development of mines for other minerals, better prospects in the cotton sector, and increased diversification in the agriculture sector. Consequently, real GDP growth is projected to average 7.3 percent in 2017-31, compared with 6.2 percent in the previous DSA. The noninterest current account deficit, although remaining moderate, is forecast to be higher than in the 2010 DSA because demand for oil and capital goods imports is expected to remain strong, in line with the projected increase in public investment, and improved economic prospects. Similarly, the external debt path is less favorable than in the previous DSA, with the rate of debt accumulation increasing steadily during 2011-20, before stabilizing over the long-term. Fiscal consolidation efforts are expected to be intensified to increase the domestic resource contribution to investment financing: tax revenue is forecast to increase from 15.6 percent of GDP in 2017 to 17.3 percent of GDP in 2031 thanks to a combination of increased revenue from mining and private sector activities and efficiency gains in tax administration; and the overall fiscal balance (including grants) is projected to improve more markedly than under the previous DSA. The macroeconomic framework also assumes that foreign aid would be consistent with historical trends in the medium-term and gradually decline as revenue performance strengthens. 


\section{Box 1. Burkina Faso: Macroeconomic Assumptions Underlying the DSA}

Real GDP is projected to average 6.4 percent in the medium term, supported by the expected increase in gold production and global prices, improved production in the cotton sector, notably thanks to higher productivity with the planned extended use of genetically modified cotton seeds, and the projected buoyant activity in the services sector. Growth projections are higher than in the 2010 DSA, reflecting a more positive outlook: the 2010 DSA outlook, which was marked by uncertainties and downside risks following the 2008-09 terms of trade and climatic shocks that adversely affected economic activity. In the longer term, growth prospects are expected to be enhanced through: (i) higher and more efficient public investment, particularly in infrastructure. Key projects under the PRSP include the Samendeni dam, the Bagre growth pole, and the Donsin airport; (ii) increased energy supply as planned investments in the sector are completed; (iii) implementation of diversification initiatives scheduled in the new PRSP with greater participation from the private sector and; (iv) continued implementation of growth-enhancing structural reform measures. In this vein, an efficient implementation of the financial sector strategy will be critical in broadening access to financial services and supporting private sector development. Real GDP is forecast to expand by 7.4 percent on average during 2017-31, despite a projected deceleration in export growth, as explained below, thanks to the expected impact of higher public investment on infrastructure and public works, and the anticipated growth in the services sector.

Inflation is expected to remain moderate and in the low-single digits, as the authorities plan to intensify measures initiated in recent years to support agriculture production, which have resulted in increased supply of agricultural food products and helped contain inflationary pressures. On this basis, and assuming moderate increase in import prices, as well as continued prudent regional monetary policy, inflation is forecast to remain below 3 percent during the projection period.

The external current account deficit, excluding grants, is forecast at about 10 percent of GDP on average in the medium to long term. Under the baseline scenario, higher export growth assumptions compared with the previous DSA reflect the expected improvement for gold and cotton export earnings as WEO projections show that gold and cotton prices will on average remain at the current high levels for the next two decades. Over the long term, export growth is projected to remain strong, but decelerating towards the end of the period. These projections reflect conservative assumptions on prospective production in the agriculture, and cotton sectors in view of uncertainties on weather conditions over the long term; and a moderate increase in gold export volume taking into account the lifespan of existing mines. Imports are expected to remain strong as investment increases and oil prices are projected to remain high. The external current account (excluding official transfers) is projected to widen from 9.9 percent of GDP in 2012 to about 11 percent of GDP in 2016, before declining to 8 percent in 2027 and 61/2 percent of GDP in 2031.

The basic primary fiscal deficit is expected to average 1.4 percent of GDP during 2012-16, and to decline over the long term. This mainly reflects a projected strong revenue mobilization based on increased efficiency in revenue collecting agencies, measures to curb fraud and tax evasion, and to modernize tax administrations. These assumptions are more optimistic than under the previous DSA. They take into account the impact of the 2010 tax reform strategy and prospects for higher taxes in the mining sector. The anticipated higher revenue mobilization would create additional fiscal space for increased government investment; and externally financed investment would average 5.8 percent of GDP in 2017-30, thus strengthening the authorities' efforts to accelerate growth. The DSA macroframework assumes that current transfers would average about 4 percent of GDP during 2017-31, while investment outlays would reach some 13 percent of GDP over the medium to long term, compared with about 11 percent in the last 10 years. External budget support is assumed to average 3.6 percent of GDP during 2017-31 
4. Debt dynamics are positively affected by the higher growth and export assumptions. DSA results show that under the baseline scenario, at the end of the projection period, the PV of debt-to-GDP ratio deteriorates only marginally compared with the previous DSA, despite a higher rate of external debt accumulation. In the external sector, the PV of the debt-to-exports ratio breaches the policy-dependent threshold nearly 10 years later than in the previous DSA thanks to the robust performance of the export sector, and decelerates thereafter. Nevertheless, those improvements could be jeopardized by terms of trade and weather-related shocks that could affect Burkina Faso's GDP and export growths.

\section{External Debt Sustainability Analysis}

5. The external debt sustainability analysis shows that the risk of debt distress is high because the PV of debt-to-exports ratio deteriorates during the projection period (Table 2 and Figure 1). In the baseline scenario, it is projected to increase from 71 percent in 2011 to 114 percent by 2021, and 176 percent in 2031, well-above the 150 percent threshold. The DSA shows comparable results under alternative scenarios. In particular, the PV of debt-to-exports ratio would reach 273 percent by 2031 under the most extreme shock, which assumes less favorable borrowing conditions for new debt (an increase in interest rate of 2 percentage points). These results suggest that Burkina Faso's long-term debt profile would deteriorate significantly if investment-financing needs were covered with nonconcessional loans. An alternative scenario assuming a lower grant element over the long term produces similar results (Figure 2). The PV of debt-to-exports ratio would also breach the policy-dependent indicative threshold in the case of a shock that would prevent the projected improvement in exports earnings, or other key macroeconomic variables.

\section{The DSA results indicate that other external debt indicators would remain} below their policy-dependent thresholds. Under the baseline and alternative scenarios, the PV of debt-to-GDP ratio and the PV of debt-to-revenue ratio increase somewhat, without breaching their respective indicative thresholds during the projection period. For both indicators, the standard stress tests do not point to particular vulnerability to shocks (Table 2). In particular, under the assumption of less favorable borrowing conditions for new loans, the PV of debt-to-GDP ratio increases from 17 percent in 2011 to about 24 percent in 2031 (with a 40 percent threshold); and the PV of debt-to-revenue ratio increases from 108 percent in 2011 to 123 percent in 2031 (with an indicative threshold of 250 percent).

\section{Results from DSA stress tests are consistent with downside risks to Burkina}

Faso's medium-term outlook, which are related to the economy's vulnerability to terms of trade shocks and fluctuations in climatic conditions that may affect economic growth and export earnings. While these shocks may affect exports and growth and increase the PV of debt-to-exports ratio, sensitivity analysis shows that a positive shock leading to an 
export growth of about 8 percent during 2017-31 (compared with 5.3 percent in the DSA framework) would lower the risk of debt distress to moderate levels.

\section{Public Debt Sustainability Analysis}

\section{The DSA results do not change with the inclusion of domestic debt in the} analysis (Table 3). Burkina Faso's stock of domestic debt amounted to about 3.2 percent of GDP at end- 2010. It comprises government bonds ( 82 percent) and consolidated liabilities to the banking system. Since the stock of domestic debt is low, and projected to decline based on repayment schedules, ${ }^{3}$ DSA results on public debt are similar to the above-mentioned results on external debt.

\section{Debt Management Issues}

9. Debt management capacity needs further improvement. The authorities have taken measures in recent years to enhance debt management capacity. The World Bank mission (March 2011) on Debt Management Performance Assessment (DeMPA), concluded that Burkina Faso had made significant progress on most debt management indicators, compared with the 2008 DeMPA assessment. However, some weaknesses remained, covering mostly: (i) the lack of a well-articulated medium-term debt management strategy (MTDS); (ii) weak auditing procedures; (iii) lack of procedures to take into account the cost and risks of prospective loans; (iv) inadequate controls of the filing system and; (iv) weak procedures for database access rights. The authorities are continuing efforts to strengthen debt management capacity, notably through training and increased Information Technology resources. They are also planning to request technical assistance from the IMF and the World Bank for the preparation of a MTDS in 2012.

10. Burkina Faso is classified as a "low debt management capacity" country under the IMF/World Bank Debt Limits Framework. The authorities are hopeful that further progress on debt management in 2011-12, would support an upgrade to a "higher capacity", leading to some flexibility on borrowing conditions.

\section{Authorities Views}

11. The authorities concurred with the DSA results and reaffirmed commitments to prudent debt policies. They stressed, however, that while maintaining an overall prudent borrowing policy, some flexibility was needed under the current IMF/WB LICs debt limits framework. They believe that access to nonconcessional borrowing would support their efforts to mobilize increased financing and scale-up investment under the new PRSP.

\footnotetext{
${ }^{3}$ Although financing from the WAEMU regional bond market is a financing option in the medium to long term, the DSA assumes that the authorities would not contract new domestic debt over the projection period. This assumption is consistent with the fact that so far bonds issuance are done on an annual basis.
} 


\section{CONCLUSION}

12. Burkina Faso is subject to a high risk of debt distress. DSA results indicate that while other debt burden indicators are well-below their policy-dependent indicative thresholds, the PV of debt-to-exports ratio is projected to breach its policy threshold in the long term. In addition, Burkina Faso's external debt is vulnerable to shocks that may adversely affect export earnings. The results highlight the need for continued prudent borrowing policies, fiscal consolidation, and economic diversification. 


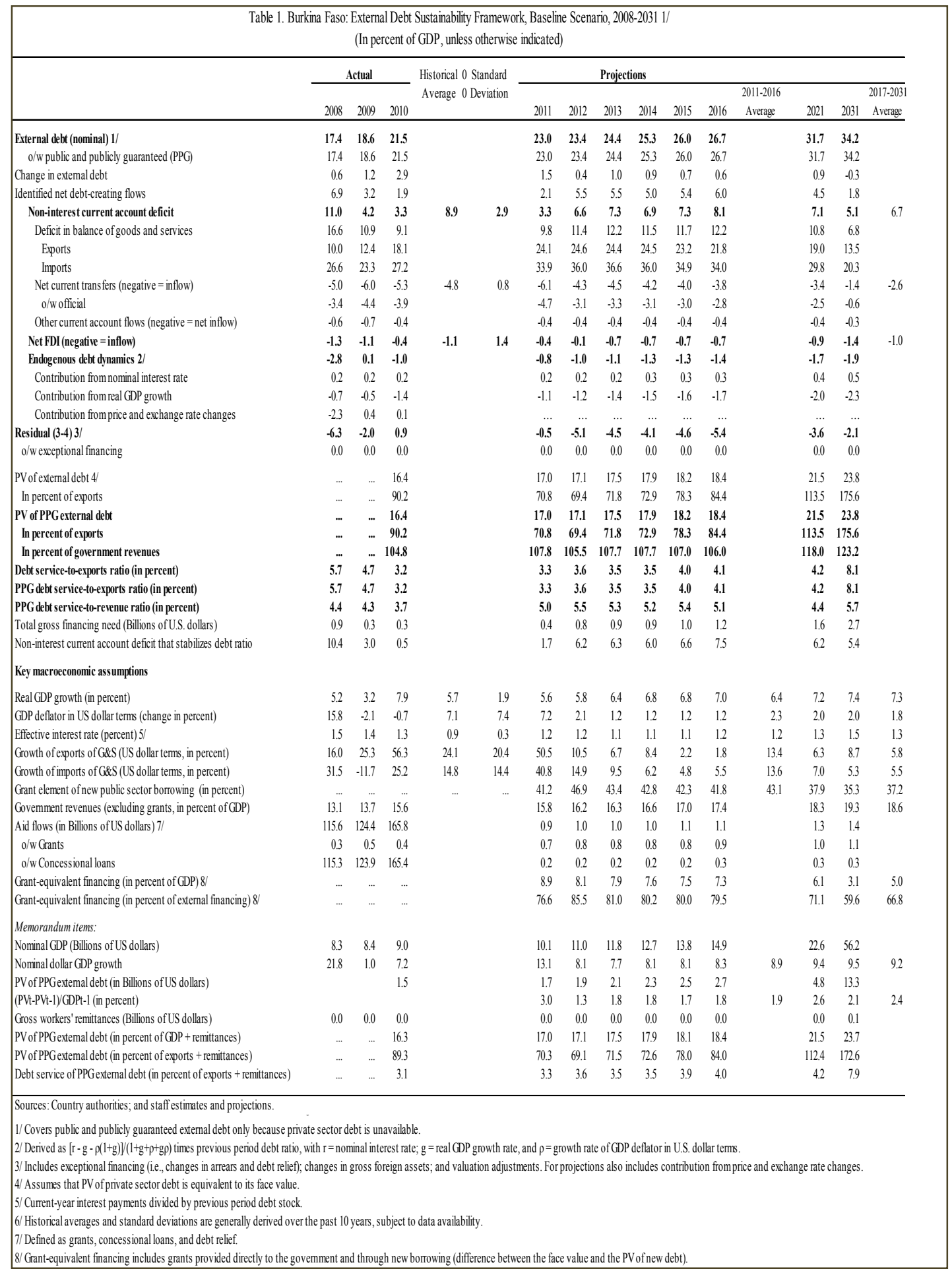

\section{CInternational Monetary Fund. Not for Redistribution}




\begin{tabular}{|c|c|c|c|c|c|c|c|c|}
\hline & \multicolumn{8}{|c|}{ Projections } \\
\hline & 2011 & 2012 & 2013 & 2014 & 2015 & 2016 & 2021 & 2031 \\
\hline \multicolumn{9}{|c|}{ PV of debt-to GDP ratio } \\
\hline Baseline & 17 & 17 & 18 & 18 & 18 & 18 & 22 & 24 \\
\hline \multicolumn{9}{|l|}{ A. Alternative Scenarios } \\
\hline A1. Key variables at their historical averages in 2011-2031 1/ & 17 & 17 & 18 & 18 & 18 & 18 & 23 & 30 \\
\hline A2. New public sector loans on less favorable terms in 2011-20312 & 17 & 18 & 19 & 20 & 22 & 23 & 30 & 37 \\
\hline \multicolumn{9}{|l|}{ B. Bound Tests } \\
\hline B1. Real GDP growth at historical average minus one standard deviation in 2012-2013 & 17 & 17 & 18 & 19 & 19 & 19 & 22 & 25 \\
\hline B2. Export value growth at historical average minus one standard deviation in 2012-2013 3/ & 17 & 18 & 20 & 20 & 20 & 20 & 23 & 24 \\
\hline B3. US dollar GDP deflator at historical average minus one standard deviation in 2012-2013 & 17 & 17 & 18 & 19 & 19 & 19 & 22 & 25 \\
\hline B4. Net non-debt creating flows at historical average minus one standard deviation in 2012-2013 4/ & 17 & 18 & 19 & 19 & 19 & 20 & 22 & 24 \\
\hline B5. Combination of B1-B4 using one-half standard deviation shocks & 17 & 16 & 15 & 16 & 16 & 16 & 20 & 23 \\
\hline B6. One-time 30 percent nominal depreciation relative to the baseline in $20125 /$ & 17 & 24 & 25 & 25 & 26 & 26 & 30 & 34 \\
\hline \multicolumn{9}{|c|}{ PV of debt-to-exports ratio } \\
\hline Baseline & 71 & 69 & 72 & 73 & 78 & 84 & 114 & 176 \\
\hline \multicolumn{9}{|l|}{ A. Alternative Scenarios } \\
\hline A1. Key variables at their historical averages in 2011-2031 1/ & 71 & 70 & 72 & 74 & 79 & 84 & 119 & 224 \\
\hline A2. New public sector loans on less favorable terms in 2011-2031 2 & 71 & 73 & 79 & 83 & 93 & 104 & 158 & 273 \\
\hline \multicolumn{9}{|l|}{ B. Bound Tests } \\
\hline B1. Real GDP growth at historical average minus one standard deviation in 2012-2013 & 71 & 69 & 72 & 73 & 78 & 84 & 113 & 175 \\
\hline B2. Export value growth at historical average minus one standard deviation in 2012-2013 3/ & 71 & 78 & 89 & 90 & 96 & 102 & 132 & 196 \\
\hline B3. US dollar GDP deflator at historical average minus one standard deviation in 2012-2013 & 71 & 69 & 72 & 73 & 78 & 84 & 113 & 175 \\
\hline B4. Net non-debt creating flows at historical average minus one standard deviation in 2012-2013 4/ & 71 & 71 & 77 & 78 & 83 & 90 & 117 & 177 \\
\hline B5. Combination of B1-B4 using one-half standard deviation shocks & 71 & 64 & 58 & 59 & 64 & 69 & 97 & 156 \\
\hline B6. One-time 30 percent nominal depreciation relative to the baseline in $20125 /$ & 71 & 69 & 72 & 73 & 78 & 84 & 113 & 175 \\
\hline \multicolumn{9}{|c|}{ PV of debt-to-revenue ratio } \\
\hline Baseline & 108 & 105 & 108 & 108 & 107 & 106 & 118 & 123 \\
\hline \multicolumn{9}{|l|}{ A. Alternative Scenarios } \\
\hline A1. Key variables at their historical averages in 2011-2031 1/ & 108 & 106 & 108 & 109 & 109 & 105 & 124 & 157 \\
\hline A2. New public sector loans on less favorable terms in 2011-2031 2 & 108 & 111 & 118 & 123 & 127 & 131 & 164 & 191 \\
\hline \multicolumn{9}{|l|}{ B. Bound Tests } \\
\hline B1. Real GDP growth at historical average minus one standard deviation in 2012-2013 & 108 & 107 & 112 & 112 & 111 & 110 & 123 & 128 \\
\hline B2. Export value growth at historical average minus one standard deviation in 2012-2013 3/ & 108 & 111 & 121 & 121 & 119 & 117 & 125 & 125 \\
\hline B3. US dollar GDP deflator at historical average minus one standard deviation in 2012-2013 & 108 & 108 & 111 & 112 & 111 & 110 & 122 & 127 \\
\hline B4. Net non-debt creating flows at historical average minus one standard deviation in 2012-2013 4/ & 108 & 108 & 116 & 115 & 114 & 112 & 122 & 124 \\
\hline B5. Combination of B1-B4 using one-half standard deviation shocks & 108 & 101 & 94 & 95 & 95 & 95 & 110 & 119 \\
\hline B6. One-time 30 percent nominal depreciation relative to the baseline in 20125 / & 108 & 149 & 152 & 152 & 151 & 150 & 166 & 174 \\
\hline
\end{tabular}

\section{CInternational Monetary Fund. Not for Redistribution}


Table 2.Burkina Faso: Sensitivity Analysis for Key Indicators of Public and Publicly Guaranteed External Debt, 2011-2031 (continued) (In percent)

Debt service-to-exports ratio

Baseline

\section{A. Alternative Scenarios}

A1. Key variables at their historical averages in 2011-2031 1/

A2. New public sector loans on less favorable terms in 2011-2031 2

\section{Debt service-to-exports ratio}

B. Bound Tests

B1. Real GDP growth at historical average minus one standard deviation in 2012-2013

B2. Export value growth at historical average minus one standard deviation in 2012-2013 3/

B3. US dollar GDP deflator at historical average minus one standard deviation in 2012-2013

B4. Net non-debt creating flows at historical average minus one standard deviation in 2012-2013 4/

B5. Combination of B1-B4 using one-half standard deviation shocks

B6. One-time 30 percent nominal depreciation relative to the baseline in 20125 /

$\begin{array}{lllllll}3 & 4 & 4 & 4 & 4 & 4 & 4 \\ 3 & 3 & 3 & 3 & 3 & 3 & 4 \\ 3 & 4 & 3 & 4 & 4 & 5 & 6\end{array}$

4

4

$6 \quad 14$

\section{Debt service-to-revenue ratio}

Baseline

A. Alternative Scenarios

A1. Key variables at their historical averages in 2011-2031 1/

A2. New public sector loans on less favorable terms in 2011-2031 2

$\begin{array}{llllllll}3 & 4 & 4 & 4 & 4 & 4 & 4 & 8 \\ 3 & 4 & 4 & 4 & 5 & 5 & 5 & 9 \\ 3 & 4 & 4 & 4 & 4 & 4 & 4 & 8 \\ 3 & 4 & 4 & 4 & 4 & 4 & 4 & 8 \\ 3 & 4 & 3 & 3 & 3 & 4 & 3 & 7 \\ 3 & 4 & 4 & 4 & 4 & 4 & 4 & 8\end{array}$

\section{B. Bound Tests}

B1. Real GDP growth at historical average minus one standard deviation in 2012-2013

B2. Export value growth at historical average minus one standard deviation in 2012-2013 3/

B3. US dollar GDP deflator at historical average minus one standard deviation in 2012-2013

B4. Net non-debt creating flows at historical average minus one standard deviation in 2012-2013 4/

B5. Combination of B1-B4 using one-half standard deviation shocks

B6. One-time 30 percent nominal depreciation relative to the baseline in 2012 5/

Memorandum item:

Grant element assumed on residual financing (i.e., financing required above baseline) 6/

Sources: Country authorities; and staff estimates and projections.

1/ Variables include real GDP growth, growth of GDP deflator (in U.S. dollar terms), non-interest current account in percent of GDP, and non-debt creating flows.

2/ Assumes that the interest rate on new borrowing is by 2 percentage points higher than in the baseline., while grace and maturity periods are the same as in the baseline.

3/ Exports values are assumed to remain permanently at the lower level, but the current account as a share of GDP is assumed to return to its baseline level after the shock

(implicitly assuming an offsetting adjustment in import levels).

4/ Includes official and private transfers and FDI.

5 / Depreciation is defined as percentage decline in dollar/local currency rate, such that it never exceeds 100 percent.

6/ Applies to all stress scenarios except for A2 (less favorable financing) in which the terms on all new financing are as specified in footnote 2. 


\begin{tabular}{|c|c|c|c|c|c|c|c|c|c|c|c|c|c|c|c|}
\hline \multicolumn{16}{|c|}{$\begin{array}{l}\text { Table 3.Burkina Faso: Public Sector Debt Sustainability Framework, Baseline Scenario, 2008-2031 } \\
\text { (In percent of GDP, unless otherwise indicated) }\end{array}$} \\
\hline & \multicolumn{3}{|c|}{ Actual } & \multirow[b]{2}{*}{ Average } & \multirow[b]{2}{*}{$\begin{array}{r}\text { Standard } \\
\text { Deviation }\end{array}$} & \multicolumn{4}{|l|}{ Estimate } & \multicolumn{3}{|c|}{ Projections } & & \\
\hline & 2008 & 2009 & 2010 & & & 2011 & 2012 & 2013 & 2014 & 2015 & 2016 & $\begin{array}{l}2011-16 \\
\text { Average }\end{array}$ & 2021 & 2031 & $\begin{array}{l}2017-31 \\
\text { Average }\end{array}$ \\
\hline Public sector debt 1 / & 20.1 & 22.7 & 24.7 & & & 26.5 & 26.0 & 26.2 & 26.4 & 26.7 & 27.0 & & 31.7 & 34.2 & \\
\hline Change in public sector debt & -0.2 & 2.7 & 2.0 & & & 1.8 & -0.5 & 0.2 & 0.2 & 0.3 & 0.3 & & 0.9 & -0.3 & \\
\hline Identified debt-creating flows & 3.0 & 1.6 & 4.6 & & & 1.1 & 1.2 & 0.7 & 0.3 & 0.0 & -0.2 & & 1.0 & -0.4 & \\
\hline Primary deficit & 4.1 & 4.3 & 5.1 & 2.2 & 6.5 & 3.5 & 2.5 & 2.2 & 1.9 & 1.7 & 1.5 & 2.2 & 3.3 & 2.2 & 2.8 \\
\hline Revenue and grants & 17.1 & 19.6 & 20.1 & & & 22.8 & 23.1 & 22.8 & 22.8 & 23.1 & 23.3 & & 22.8 & 21.3 & \\
\hline of which: grants & 4.0 & 5.9 & 4.6 & & & 7.0 & 6.9 & 6.5 & 6.2 & 6.1 & 5.9 & & 4.6 & 2.0 & \\
\hline Primary (noninterest) expenditure & 21.2 & 23.9 & 25.3 & & & 26.3 & 25.6 & 24.9 & 24.8 & 24.8 & 24.8 & & 26.1 & 23.5 & \\
\hline Automatic debt dynamics & -1.0 & -1.9 & -0.4 & & & -2.3 & -1.3 & -1.5 & -1.6 & -1.7 & -1.7 & & -2.3 & -2.5 & \\
\hline Contribution from interest rate/growth differential & -2.1 & -0.8 & -1.8 & & & -1.3 & -1.5 & -1.6 & -1.8 & -1.8 & -1.9 & & -2.3 & -2.5 & \\
\hline of which: contribution from average real interest rate & -1.1 & -0.2 & -0.1 & & & 0.0 & 0.0 & -0.1 & -0.1 & -0.2 & -0.2 & & -0.2 & -0.2 & \\
\hline of which: contribution from real GDP growth & -1.0 & -0.6 & -1.7 & & & -1.3 & -1.5 & -1.6 & -1.7 & -1.7 & -1.7 & & -2.1 & -2.4 & \\
\hline Contribution from real exchange rate depreciation & 1.1 & -1.1 & 1.4 & & & -1.0 & 0.2 & 0.2 & 0.2 & 0.2 & 0.2 & & $\ldots$ & $\ldots$ & \\
\hline Other identified debt-creating flows & -0.1 & -0.8 & -0.2 & & & 0.0 & 0.0 & 0.0 & 0.0 & 0.0 & 0.0 & & 0.0 & 0.0 & \\
\hline Privatization receipts (negative) & -0.1 & -0.8 & -0.2 & & & 0.0 & 0.0 & 0.0 & 0.0 & 0.0 & 0.0 & & 0.0 & 0.0 & \\
\hline Recognition of implicit or contingent liabilities & 0.0 & 0.0 & 0.0 & & & 0.0 & 0.0 & 0.0 & 0.0 & 0.0 & 0.0 & & 0.0 & 0.0 & \\
\hline Debt relief (HIPC and other) & 0.0 & 0.0 & 0.0 & & & 0.0 & 0.0 & 0.0 & 0.0 & 0.0 & 0.0 & & 0.0 & 0.0 & \\
\hline Other (specify, e.g. bank recapitalization) & 0.0 & 0.0 & 0.0 & & & 0.0 & 0.0 & 0.0 & 0.0 & 0.0 & 0.0 & & 0.0 & 0.0 & \\
\hline Residual, including asset changes & -3.2 & 1.0 & -2.6 & & & 0.6 & -1.7 & -0.5 & -0.1 & 0.3 & 0.5 & & -0.1 & 0.0 & \\
\hline \multicolumn{16}{|l|}{ Other Sustainability Indicators } \\
\hline PV of public sector debt & $\ldots$ & $\ldots$ & 19.5 & & & 20.5 & 19.7 & 19.4 & 19.0 & 18.8 & 18.7 & & 21.5 & 23.8 & \\
\hline o/w foreign-currency denominated & $\ldots$ & $\ldots$ & 16.4 & & & 17.0 & 17.1 & 17.5 & 17.9 & 18.2 & 18.4 & & 21.5 & 23.8 & \\
\hline o/w external & $\ldots$ & $\ldots$ & 16.4 & & & 17.0 & 17.1 & 17.5 & 17.9 & 18.2 & 18.4 & & 21.5 & 23.8 & \\
\hline PV of contingent liabilities (not included in public sector debt) & $\ldots$ & $\ldots$ & $\ldots$ & & & ... & $\ldots$ & $\ldots$ & $\ldots$ & $\ldots$ & $\ldots$ & & $\ldots$ & $\ldots$ & \\
\hline Gross financing need $2 /$ & 5.0 & 5.4 & 6.5 & & & 5.0 & 4.3 & 3.7 & 3.4 & 3.0 & 2.7 & & 4.1 & 3.3 & \\
\hline $\mathrm{PV}$ of public sector debt-to-revenue and grants ratio (in percent) & $\ldots$ & $\ldots$ & 97.0 & & & 89.8 & 85.2 & 85.0 & 83.3 & 81.5 & 80.3 & & 94.4 & 111.7 & \\
\hline PV of public sector debt-to-revenue ratio (in percent) & $\ldots$ & $\ldots$ & 125.3 & & & 129.5 & 121.4 & 118.8 & 114.6 & 111.1 & 107.8 & & 118.0 & 123.2 & \\
\hline o/w external $3 /$ & $\ldots$ & $\ldots$ & 104.8 & & & 107.8 & 105.5 & 107.7 & 107.7 & 107.0 & 106.0 & & 118.0 & 123.2 & \\
\hline Debt service-to-revenue and grants ratio (in percent) 4 / & 5.4 & 5.2 & 6.7 & & & 6.7 & 7.6 & 6.9 & 6.5 & 5.8 & 5.4 & & 3.5 & 5.1 & \\
\hline Debt service-to-revenue ratio (in percent) $4 /$ & 7.1 & 7.4 & 8.6 & & & 9.6 & 10.8 & 9.6 & 8.9 & 7.9 & 7.2 & & 4.4 & 5.7 & \\
\hline Primary deficit that stabilizes the debt-to-GDP ratio & 4.3 & 1.7 & 3.2 & & & 1.7 & 3.0 & 1.9 & 1.7 & 1.4 & 1.2 & & 2.4 & 2.5 & \\
\hline \multicolumn{16}{|l|}{ Key macroeconomic and fiscal assumptions } \\
\hline Real GDP gowth (in percent) & 5.2 & 3.2 & 7.9 & 5.7 & 1.9 & 5.6 & 5.8 & 6.4 & 6.8 & 6.8 & 7.0 & 6.4 & 7.2 & 7.4 & 7.3 \\
\hline Average nominal interest rate on forex debt (in percent) & 1.5 & 1.4 & 1.3 & 0.9 & 0.3 & 1.2 & 1.2 & 1.1 & 1.1 & 1.1 & 1.2 & 1.2 & 1.3 & $1.5^{\prime \prime}$ & 1.3 \\
\hline Average real interest rate on domestic debt (in percent) & -3.5 & 4.8 & 2.8 & 2.9 & 3.7 & 5.2 & 5.9 & 4.1 & 4.0 & 3.9 & $3.9^{\prime \prime}$ & 4.5 & $\ldots$ & $\ldots$ & 3.4 \\
\hline Real exchange rate depreciation (in percent,+ indicates depreciation) & 7.0 & -6.7 & 8.3 & -3.2 & 10.3 & -5.0 & $\ldots$ & $\ldots$ & $\ldots$ & $\ldots$ & $\ldots$ & $\ldots$ & $\ldots$ & $\ldots$ & $\ldots$ \\
\hline Inflation rate (GDP deflator, in percent) & 7.9 & 3.4 & 2.8 & 3.0 & 2.5 & 2.1 & 2.2 & 2.0 & 2.0 & 2.0 & 2.0 & 2.0 & 2.0 & 2.0 & 2.0 \\
\hline Growth of real primary spending (deflated by GDP deflator, in percent) & -0.1 & 0.2 & 0.1 & 0.1 & 0.1 & 0.1 & 0.0 & 0.0 & 0.1 & 0.1 & 0.1 & 0.1 & 0.1 & 0.1 & 0.1 \\
\hline Grant element of new external borrowing (in percent) & ... & $\ldots$ & $\ldots$ & $\ldots$ & $\ldots$ & 41.2 & 46.9 & 43.4 & 42.8 & 42.3 & 41.8 & 43.1 & 37.9 & 35.3 & $\ldots$ \\
\hline $\begin{array}{l}\text { Sources: Country authorities; and staff estimates and projections. } \\
1 / \text { Public sector debt is defined as gross debt for the general government an } \\
\text { 2/ Gross financing need is defined as the primary deficit plus debt service } \\
\text { 3/Revenues excluding grants. } \\
\text { 4/ Debt service is defined as the sum of interest and amortization of medi } \\
\text { 5/ Historical averages and standard deviations are generally derived over th }\end{array}$ & $\begin{array}{l}\text { nonfinancial } \\
\text { us the stock } \\
\text { and long-ter } \\
\text { past } 10 \text { year }\end{array}$ & $\begin{array}{l}\text { I public sec } \\
\text { sof short-tc } \\
\text { rs, sebt. }\end{array}$ & tor. & end of the $\mathrm{k}$ & st period. & & & & & & & & & & \\
\hline
\end{tabular}

\section{CInternational Monetary Fund. Not for Redistribution}




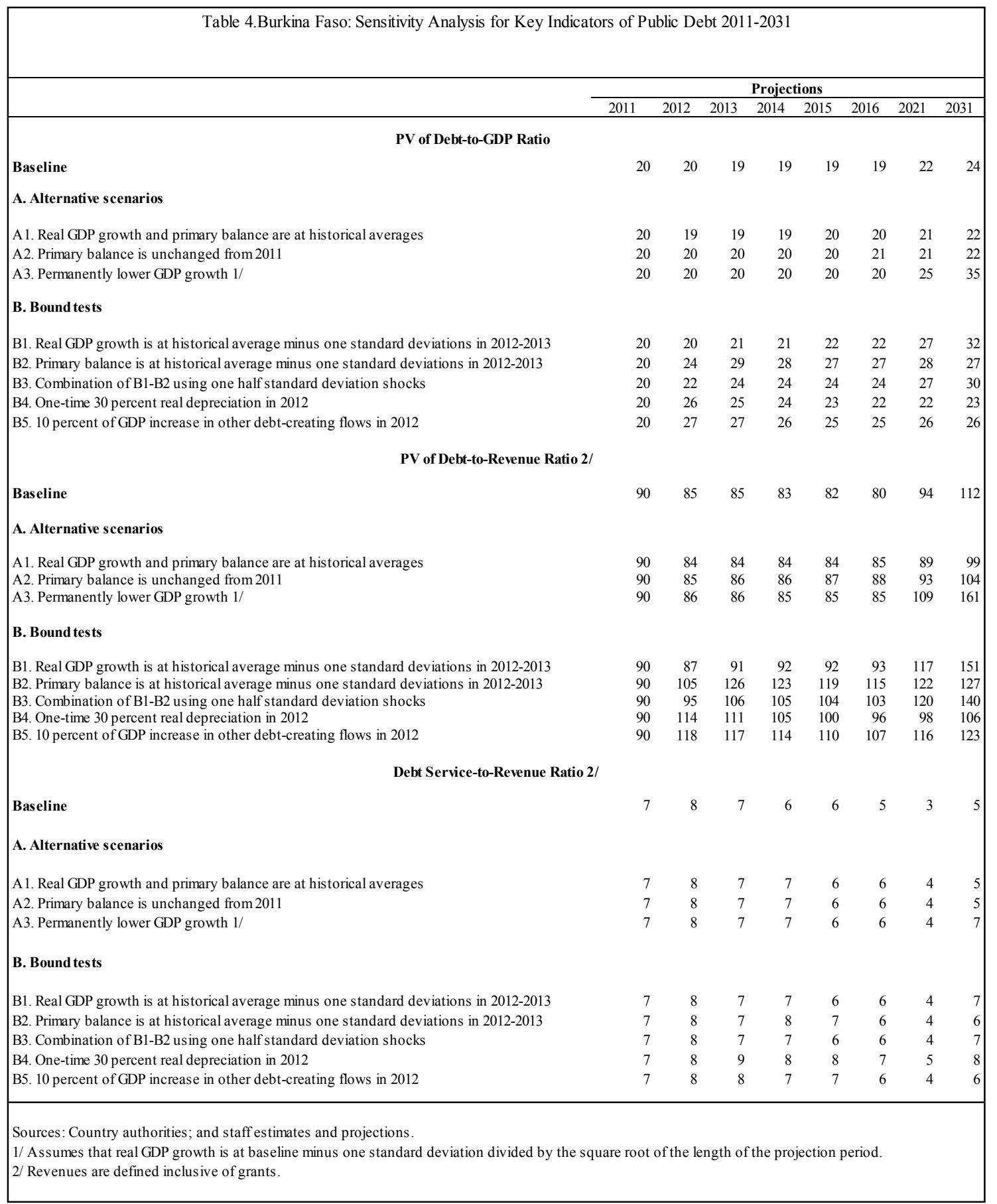

\section{CInternational Monetary Fund. Not for Redistribution}




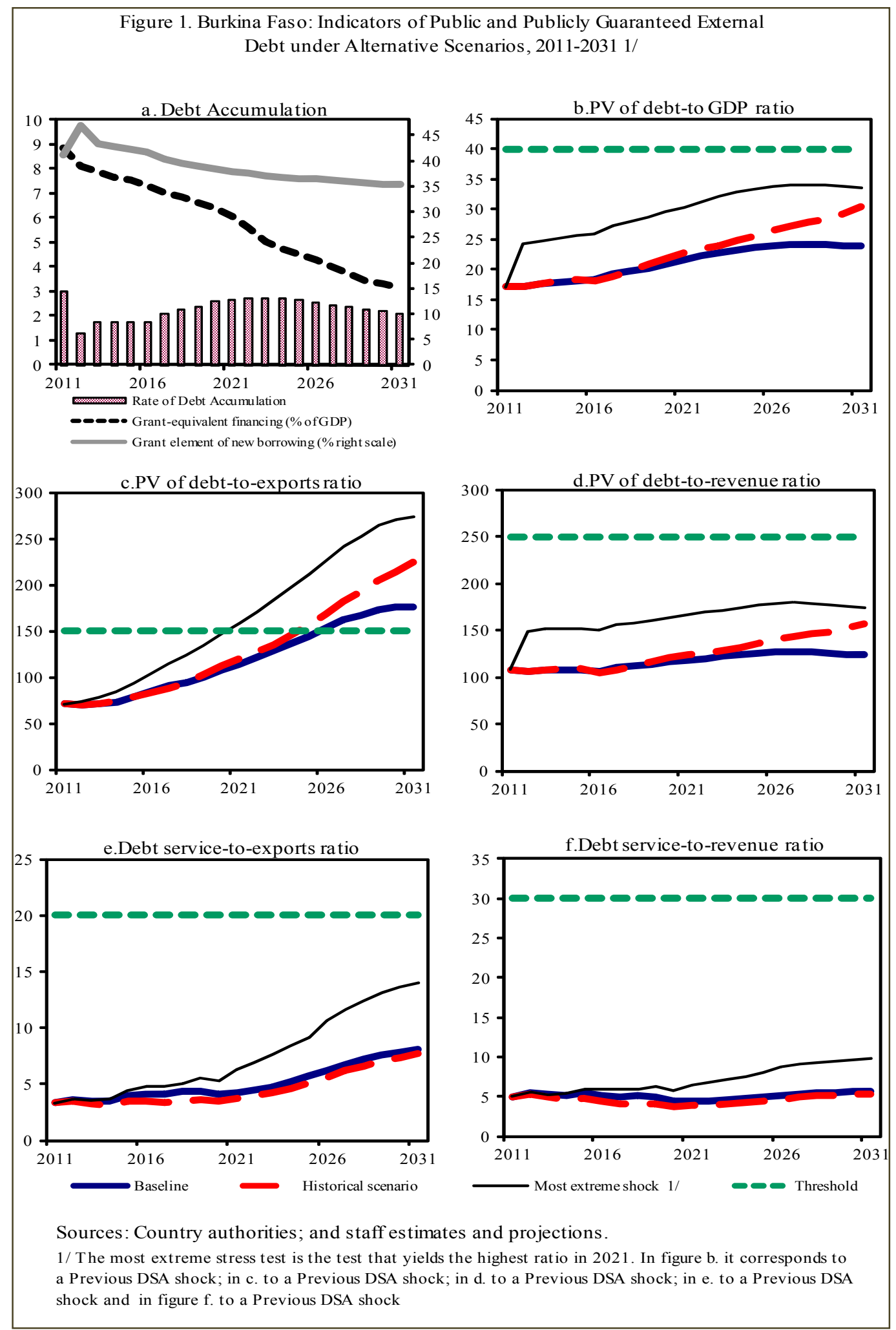

CInternational Monetary Fund. Not for Redistribution 


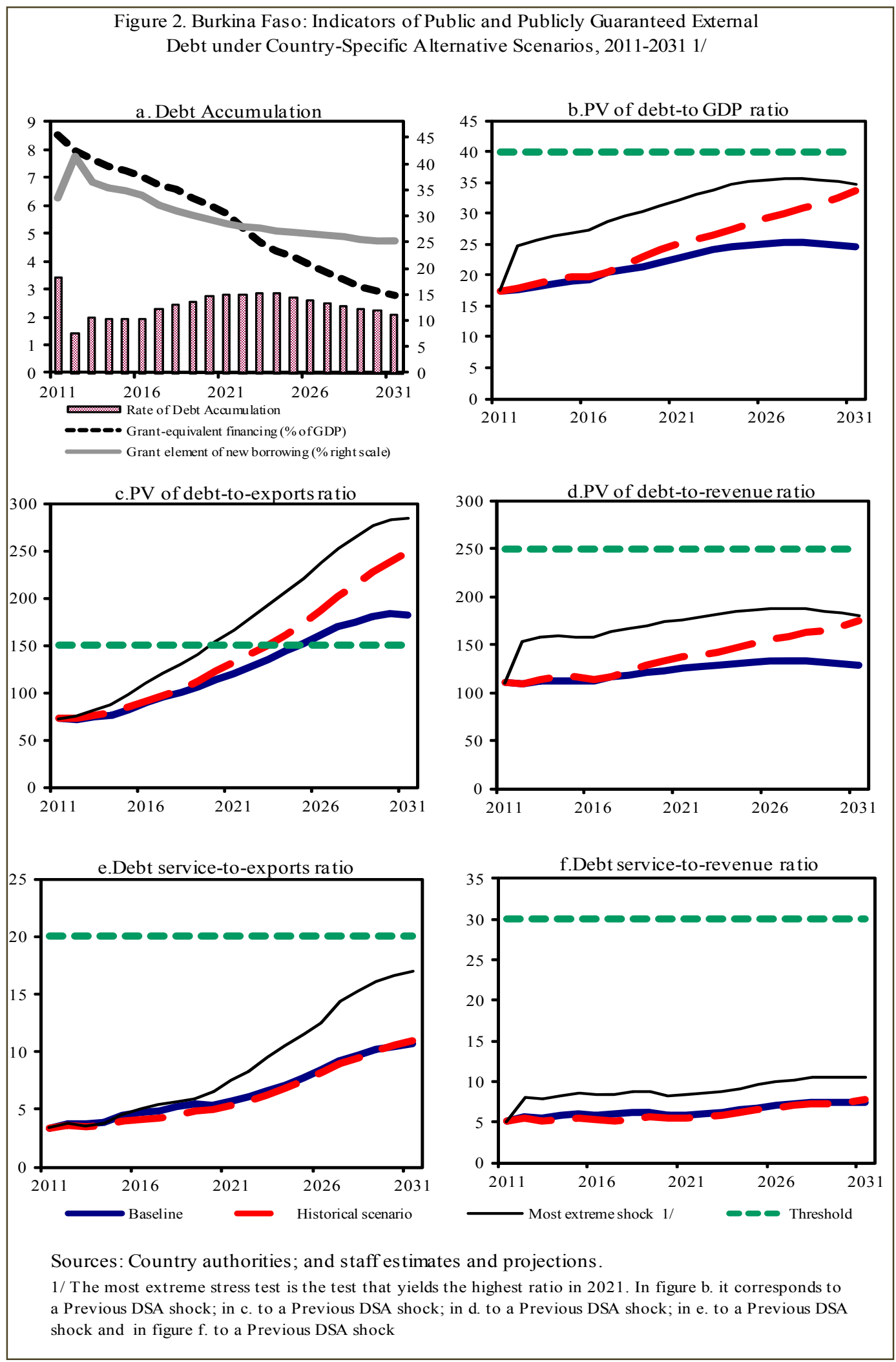

CInternational Monetary Fund. Not for Redistribution 
Figure 3.Burkina Faso: Indicators of Public Debt Under Alternative Scenarios, 2011-2031 1/
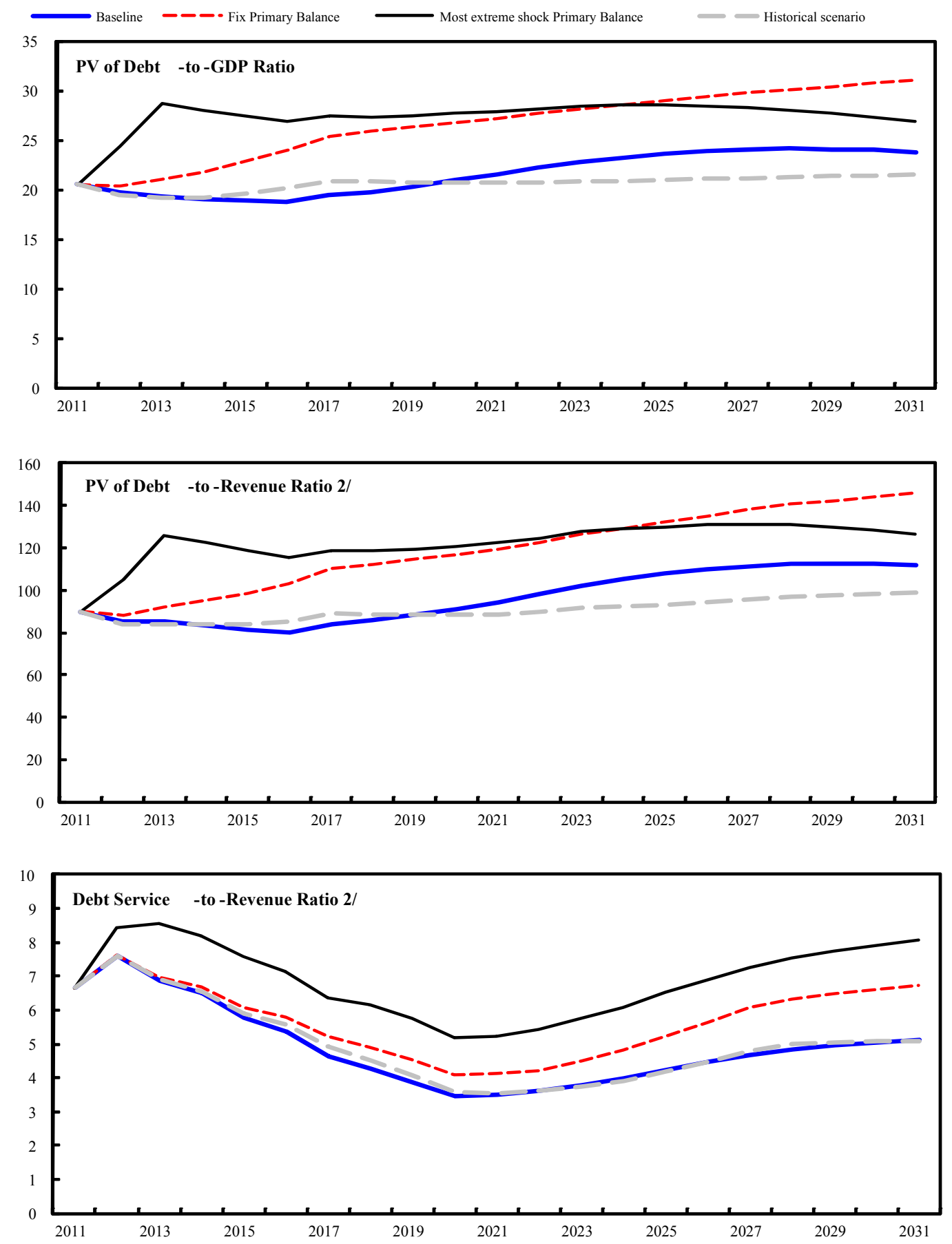

Sources: Country authorities; and staff estimates and projections.

1/ The most extreme stress test is the test that yields the highest ratio in 2021 .

2/ Revenues are defined inclusive of grants. 


\section{INTERNATIONAL MONETARY FUND}

BURKINA FASO

\section{Staff Report for the 2011 Article IV Consultation and the Third Review Under the Extended Credit Facility-Informational Annex}

Prepared by the African Department

Approved by Michael Atingi Ego and Thomas Dorsey

December 8, 2011

- $\quad$ Relations with the Fund. Describes financial and technical assistance from the Fund and provides information on the safeguards assessment and exchange rate system. Outstanding purchases and loans amounted to SDR 87.63 million (145.57 percent of quota) at end-May 2011.

- JMAP Implementation. Describes Bank-Fund collaboration.

- $\quad$ Statistical Issues. Assesses the quality of statistical data. Weaknesses in a broad range of economic statistics are hampering the analyses of economic developments in the country. 


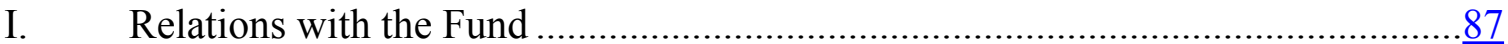

II. Joint Management Action Plan (JMAP) Implementation..............................100

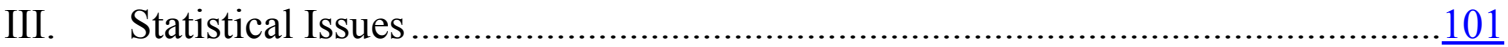




\section{Relations with the Fund}

(As of October 20, 2011)

I. Membership Status: Joined: May 2, 1963;

II. General Resources Account:

SDR Million

Quota

60.20

Fund holdings of currency (Exchange Rate)

52.7

Reserve Tranche Position

7.52

SDR Million

57.58

48.15

Article VIII

III. SDR Department:

Net cumulative allocation

Holdings

SDR Million

87.63

\%Quota

100.00

87.55

12.50

\%Allocation

100.00

83.62

IV. Outstanding Purchases and Loans:

ECF Arrangements

\%Quota

145.57

V. Latest Financial Arrangements:

Date of

Expiration

Amount Approved Amount Drawn

Type

Arrangement

Date

ECF

Jun 14, 2010

Jun 13, 2013

(SDR Million)

(SDR Million)

$\mathrm{ECF}^{1 /}$

Apr 23, 2007

Apr 22, 2010

46.15

20.35

$\mathrm{ECF}^{1 /}$

Jun 11, 2003

Sep 30, 2006

48.16

47.16

30.10

30.10

${ }^{1 /}$ Formerly PRGF.

\section{Projected Payments to Fund ${ }^{1 /}$}

(SDR Million; based on existing use of resources and present holdings of SDRs):

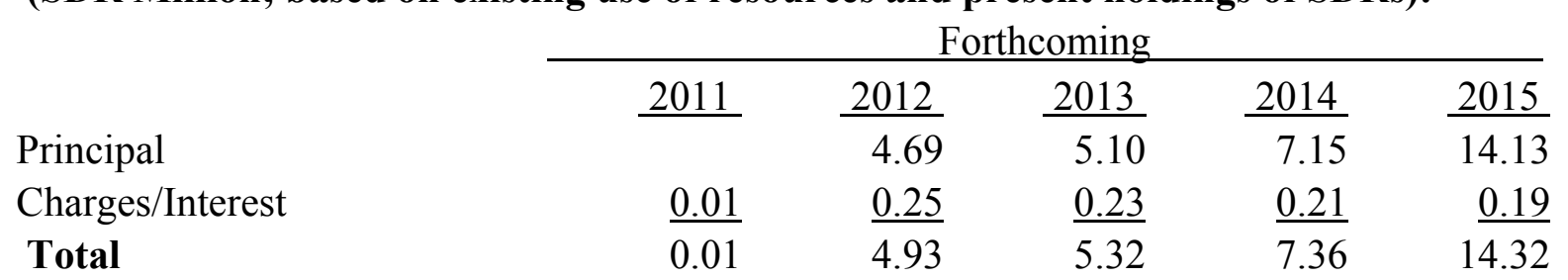

${ }^{1 /}$ When a member has overdue financial obligations outstanding for more than three months, the amount of such arrears will be shown in this section. 
VII. Implementation of HIPC Initiative:

Original Enhanced

I. Commitment of HIPC assistance

Framework Framework

$\underline{\text { Total }}$

Decision point date

Sep 1997 Jul 2000

Assistance committed

by all creditors (US\$ Million) ${ }^{1 /}$

229.00

324.15

Of which: IMF assistance (US\$ million)

$21.70 \quad 35.88$

(SDR equivalent in millions)

$16.30 \quad 27.67$

Completion point date

Jul 2000 Apr 2002

II. Disbursement of IMF assistance (SDR Million)

Assistance disbursed to the member

$16.30 \quad 27.67$

43.97

Interim assistance

$\begin{array}{ll}-- & 4.15\end{array}$

Completion point balance

16.30

23.52

39.82

Additional disbursement of interest income ${ }^{2 /}$

Total disbursements

$--\quad 2.01$

2.01

$16.30 \quad 29.68$

45.98

${ }^{1 /}$ Assistance committed under the original framework is expressed in net present value (NPV) terms at the completion point, and assistance committed under the enhanced framework is expressed in NPV terms at the decision point. Hence these two amounts can not be added.

${ }^{2 /}$ Under the enhanced framework, an additional disbursement is made at the completion point corresponding to interest income earned on the amount committed at the decision point but not disbursed during the interim period.

\section{Implementation of Multilateral Debt Relief Initiative (MDRI):}

I. MDRI-eligible debt (SDR Million) ${ }^{1 /}$

Financed by: MDRI Trust

Remaining HIPC resources

II. Debt Relief by Facility (SDR Million)

Eligible Debt

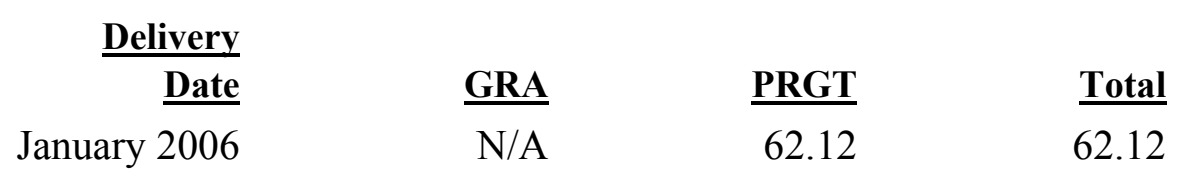

${ }^{1 /}$ The MDRI provides 100 percent debt relief to eligible member countries that qualified for the assistance. Grant assistance from the MDRI Trust and HIPC resources provide debt relief to cover the full stock of debt owed to the Fund as of end-2004 that remains outstanding at the time the member qualifies for such debt relief. 


\section{Implementation of Post-Catastrophe Debt Relief (PCDR):}

Not Applicable

\section{Safeguards Assessments:}

The Central Bank of West African States (BCEAO) is a common central bank of the countries of the West African Economic and Monetary Union (WAMU). The most recent safeguards assessment of the BCEAO was completed on March 1, 2010. The 2010 update assessment found that the BCEAO continues to have controls in place at the operational level. The overall governance framework needed nonetheless to be strengthened by the addition of an audit committee to ensure that the Board of Directors exercises appropriate oversight over the control structure, including the audit mechanisms and financial statements. The Institutional Reform of the WAMU and the BCEAO completed after the approval of the safeguards report stipulated creation of the Audit Committee, which should now start working. Efforts to implement fully the International Financial Reporting Standards reporting framework should also be pursued.

\section{Exchange Rate Arrangement:}

Burkina Faso is a member of the West African Economic and Monetary Union (WAEMU) and has no separate legal tender. The union's common currency, the CFA franc, is pegged to the euro at a rate of CFAF $655.957=$ EUR 1, consistent with the official conversions rate of the French franc to the Euro and the previous fixed rate of the CFA franc to the French franc of CFAF $100=$ F 1 . On December 8, 2011, the rate of the CFA franc in terms of SDR was CFAF $877.85=$ SDR 1.0. Effective January 1, 2007, the exchange arrangement of the WAEMU countries has been reclassified to the category of conventional pegged arrangement from the category of exchange arrangement with no separate legal tender. The new classification is based on the behavior of the common currency, whereas the previous classification was based on the lack of a separate legal tender. The new classification thus only reflects a definitional change, and is not based on a judgment that there has been a substantive change in the exchange regime or other policies of the currency union or its member. The exchange system is free of restrictions on the making of payments and transfers on current international transactions. 


\section{Article IV Consultations:}

The periodicity of Burkina Faso's Article IV consultation is set in accordance with the July 15, 2002 Executive Board Decision on consultation cycles. Discussions on the 2011 Article IV consultation were held between September 29-October 14, 2011 in Ouagadougou. The staff report for the 2011 Article IV consultation was considered by the Executive Board on December XX, 2011. The staff report on the previous Article IV consultation was considered by the Executive Board on December 14, 2009. The next Article IV consultation is scheduled for September 2013.

\section{ROSC/AAP:}

An FAD mission visited Ouagadougou during May 7-18, 2001 to assist the authorities undertake a draft fiscal module of a Report on the Observance of Standards and Codes (ROSC). The final report, which was issued in July 2002, found that Burkina Faso was making good progress in a number of areas to increase the transparency and accountability of government. Additional efforts are needed to bring a number of improvements to the point of implementation, particularly with regard to expenditure tracking at the local level and external audit functions. Initial discussions indicated that the authorities broadly concurred with the mission assessment. On July 31, 2002, the authorities formally adopted an action plan based on the recommendations of the final ROSC.

An STA mission during May 8-21, 2003 assisted the authorities in preparing a data ROSC. The report was published in March 2004. The mission found that most of the methodologies used in the compilation of macroeconomic statistics are in broad conformity with internationally accepted guidelines. However, most datasets are affected by limited or impaired source data arising from irregularity in the conduct of surveys (national accounts), use of outdated weights (CPI), or low response rate to surveys (balance of payments). For CPI and government finance statistics, data dissemination meets the SDDS requirement, but for other macroeconomic datasets, timeliness falls short of GDDS recommendations. The authorities broadly concurred with the main findings of the mission as well as the recommendations made to address them.

The team, jointly with World Bank staff, also discussed a HIPC Initiative Assessment and Action Plan (AAP) with the authorities. The aim was to assess the capacity of the public expenditure management system to track poverty-reducing public expenditures under the HIPC Initiative and the need for technical assistance to enhance that capacity. The mission secured the officials' approval of the jointly prepared preliminary assessment; identified the main needs for technical assistance on upgrading the capacity to track such expenditures; and drew up a draft outline action plan. This plan identifies the main needs for further technical 
assistance to improve tracking of poverty-reducing expenditures. The AAP has been endorsed by the authorities. 


\section{Technical Assistance:}

Significant technical assistance has been provided since 1989 , more recently especially in the fiscal area:

\begin{tabular}{|c|c|c|c|}
\hline Department & $\begin{array}{l}\text { Type of } \\
\text { Assistance }\end{array}$ & Time of Delivery & Purpose \\
\hline AFRITAC & Tax Advisor & $\begin{array}{l}\text { February } 7-11 \text {, } \\
2005\end{array}$ & $\begin{array}{l}\text { Review the progress made on: } \\
\text { (1) the setup of the Large Taxpayer } \\
\text { Unit and the Medium Taxpayers } \\
\text { Office; (2) the steps to strengthen } \\
\text { the fiscal control; and (3) the } \\
\text { corporate registry reform. }\end{array}$ \\
\hline AFRITAC & $\begin{array}{l}\text { Customs } \\
\text { Advisor }\end{array}$ & $\begin{array}{l}\text { February } 14-18 \\
2005\end{array}$ & $\begin{array}{l}\text { Provide assistance to control transit } \\
\text { merchandises in the country and } \\
\text { travelers at Ouagadougou airport. }\end{array}$ \\
\hline AFRITAC & $\begin{array}{l}\text { Customs, short- } \\
\text { term Expert }\end{array}$ & $\begin{array}{l}\text { February } 14-23, \\
2005\end{array}$ & $\begin{array}{l}\text { Implement customs valuation code } \\
\text { and establish a database for } \\
\text { indicative import prices. }\end{array}$ \\
\hline AFRITAC & $\begin{array}{l}\text { Microfinance } \\
\text { Advisor }\end{array}$ & March 21-25, 2005 & $\begin{array}{l}\text { Assess the TA need of the Cellule } \\
\text { responsible of the supervision of } \\
\text { microfinance institutions and } \\
\text { prepare a capacity-building } \\
\text { program. }\end{array}$ \\
\hline AFRITAC & $\begin{array}{l}\text { Short-term } \\
\text { Expert }\end{array}$ & April 18-29, 2005 & $\begin{array}{l}\text { Training of auditors of the Tax } \\
\text { administration. }\end{array}$ \\
\hline AFRITAC & PEM Advisor & $\begin{array}{l}\text { June } 27 \text {, July } 1 \text {, } \\
2005\end{array}$ & $\begin{array}{l}\text { Review of the public finance } \\
\text { directives of WAEMU. }\end{array}$ \\
\hline AFRITAC & $\begin{array}{l}\text { STA Advisor } \\
\text { and Short-term } \\
\text { Expert }\end{array}$ & $\begin{array}{l}\text { June 27-July 5, } \\
2005\end{array}$ & $\begin{array}{l}\text { Assist in setting up database for the } \\
\text { TOFE (first or two scheduled } \\
\text { missions) and expand further the } \\
\text { scope of the TOFE (last of three } \\
\text { scheduled missions). }\end{array}$ \\
\hline AFRITAC & $\begin{array}{l}\text { Customs } \\
\text { Advisor visits }\end{array}$ & July 10-16, 2005 & $\begin{array}{l}\text { Advise on customs enforcement and } \\
\text { assessment of further TA needs. }\end{array}$ \\
\hline AFRITAC & Tax Advisor & August 8-12, 2005 & $\begin{array}{l}\text { (1) Review the status of } \\
\text { implementation of the } 2003 \text { FAD } \\
\text { mission's recommendations; }\end{array}$ \\
\hline
\end{tabular}




\begin{tabular}{llll}
\hline Department & $\begin{array}{l}\text { Type of } \\
\text { Assistance }\end{array}$ & Time of Delivery & Purpose \\
\hline
\end{tabular}

\begin{tabular}{|c|c|c|c|}
\hline & & & $\begin{array}{l}\text { (2) update the tax directorate's } \\
\text { action plan; and ( } 3 \text { ) asses the DGI } \\
\text { TA's needs. }\end{array}$ \\
\hline AFRITAC & $\begin{array}{l}\text { STA Short-term } \\
\text { Expert }\end{array}$ & $\begin{array}{l}\text { August 22-26, } \\
2005\end{array}$ & $\begin{array}{l}\text { Assist with putting in place the } \\
\text { database of public finances. }\end{array}$ \\
\hline AFRITAC & $\begin{array}{l}\text { Customs } \\
\text { Advisor }\end{array}$ & $\begin{array}{l}\text { August 28- } \\
\text { September 1,2005 }\end{array}$ & $\begin{array}{l}\text { Advise on customs enforcement and } \\
\text { assessment of further TA needs. }\end{array}$ \\
\hline AFRITAC & $\begin{array}{l}\text { STA Short-term } \\
\text { Expert }\end{array}$ & $\begin{array}{l}\text { August 29- } \\
\text { September 2, } 2005\end{array}$ & $\begin{array}{l}\text { Assist and set up database for the } \\
\text { TOFE (last of the two scheduled } \\
\text { missions). }\end{array}$ \\
\hline AFRITAC & $\begin{array}{l}\text { Microfinance } \\
\text { Advisor }\end{array}$ & $\begin{array}{l}\text { September 19-23, } \\
2005\end{array}$ & $\begin{array}{l}\text { Strengthen operational systems for } \\
\text { the surveillance of microfinance } \\
\text { institutions. }\end{array}$ \\
\hline AFRITAC & $\begin{array}{l}\text { STA Short-term } \\
\text { Expert }\end{array}$ & $\begin{array}{l}\text { September 19-23, } \\
2005\end{array}$ & $\begin{array}{l}\text { Assist and setting up database for } \\
\text { the TOFE (additional mission). }\end{array}$ \\
\hline AFRITAC & PEM Advisor & $\begin{array}{l}\text { October 10-14, } \\
2005\end{array}$ & $\begin{array}{l}\text { Review the status of } \\
\text { implementation the January } 2004 \\
\text { mission recommendations and } \\
\text { assess the technical assistance } \\
\text { needs. }\end{array}$ \\
\hline AFRITAC & $\begin{array}{l}\text { Microfinance } \\
\text { Advisor and } \\
\text { Short-term } \\
\text { Expert }\end{array}$ & $\begin{array}{l}\text { November } 21- \\
\text { December } 16,2005\end{array}$ & Coach in microfinance inspections. \\
\hline AFRITAC & STA Advisor & $\begin{array}{l}\text { December 6-15, } \\
2005\end{array}$ & $\begin{array}{l}\text { Review the WAEMU directives on } \\
\text { budgetary nomenclature. }\end{array}$ \\
\hline AFRITAC & $\begin{array}{l}\text { Customs } \\
\text { Advisor }\end{array}$ & $\begin{array}{l}\text { January } 23-25 \text {, } \\
2006\end{array}$ & $\begin{array}{l}\text { Strengthen the dialogue between the } \\
\text { customs administration and the } \\
\text { private sector (regional workshop). }\end{array}$ \\
\hline AFRITAC & STA Advisor & March 11-25, 2006 & Review the directive on the TOFE. \\
\hline
\end{tabular}


AFRITAC PEM Advisor March 13-17, 2006 Review the directive on the TOFE.

AFRITAC Tax

administration;

Short term

Expert

AFRITAC Customs

Advisor

FAD

Revenue

administration

mission

AFRITAC Custom Advisor April 4-14, 2006

AFRITAC Tax

administration;

Short term Expert

AFRITAC Tax Advisor

AFRITAC Microfinance

Advisor

AFRITAC Real statistic

sector Advisor

AFRITAC

Microfinance,

Short term

Expert

AFRITAC Public

expenditure

Advisors

April 17-28, 2006

July $24-28,2006$ 2006 2006

October 20, 2006
March 14-28, 2006 Assist in strengthening

(1) operations of the LTU; and

(2) tax auditing.

March 14-28, 2006 Assist in defining an action plan to improve revenue mobilization.

March 14-28, 2006 Advise on tax and customs administration reform strategy (including improvement of the large tax payer unit, and strengthening of the tax and customs organization and operations).

Strengthen the control of goods valuation.

Strengthen the management of the most important taxpayers.

Follow up the implementation of the recommendations by the FAD mission in March 2006.

July 31-August 4,

Identify the follow-up indicators from a distance.

September 11-20,

Take stock of the implementation of the recommendations by the ROSC mission in March 2004.

Accompany the agents of the Cell S-IFD.

October 2-12, 2006

Review and follow up the implementation of the priority action plan in the PF strengthening strategy. 
AFRITAC Microfinance; October 2-20, 2006 Develop agent's abilities in

Short term

Expert

AFRITAC Customs

November 20-

administration,

December 1, 2006

Short-term

Expert

AFRITAC Tax Advisor

November 20-

December 1, 2006

inspection and accompany them in the field.

Assess the implementation of preview recommendations relating to the control of goods valuation in the customs.

Strengthen capacities of the tax administration to fight tax evasion.

AFRITAC Macroeconomic March 5-9, 2007 statistics Advisor

AFRITAC Debt Advisor

March 5-16, 2007

Training in Government Statistics Manual 2001.

AFRITAC Customs

March 12-23, 2007

Advisor

Study the situation of the administrative management of the internal and external debts.

Follow up the implementation of the recommendations by the FAD mission in March 2006, and assess the implementation of the goods valuation control in the customs.

AFRITAC Macroeconomic March 19-23, 2007 statistics

Training in Government finance statistics framework.

Advisor

AFRITAC Tax Advisor

March 26-30, 2007

Assist in the implementation of the tax administration strengthening and modernization measures. 


$\begin{array}{llll}\text { AFRITAC } & \text { Tax Advisor } & \begin{array}{l}\text { May 22-June 4, } \\ 2007\end{array} & \begin{array}{l}\text { Follow up on fiscal administration. } \\ \text { AFRITAC }\end{array} \\ \text { Custom Advisor } & \text { July 16-27, 2007 } & \begin{array}{l}\text { Computerization of customs } \\ \text { procedures. }\end{array} \\ \text { Bank } & \text { July 23-27, 2007 } & \begin{array}{l}\text { Technical assistance needs } \\ \text { assessment and evaluation on bank } \\ \text { supervision. }\end{array} \\ \text { FAD } & \begin{array}{l}\text { Budget } \\ \text { management }\end{array} & \text { June 26-July 9, } & \begin{array}{l}\text { Advise on tax and customs } \\ \text { administration reform strategy } \\ \text { (including improvement of the large } \\ \text { tax payer unit, and strengthening of } \\ \text { the tax and customs organization } \\ \text { and operations). }\end{array} \\ & 2007 & & \end{array}$

STA Macroeconomic November 26statistics December 7, 2007

Support in setting up fiscal accounts for the Treasury.

FAD

Tax policy

November 27-

Review and simplification of tax reform December 12, 2007 system.

FAD/ Public financial

AFRITAC management

AFRITAC

Debt

January $28-$

Sustainability

February 1, 2008

Workshop

AFRITAC

Revenue administration

February 11-22, 2008

Assist in the implementation of the authorities' reform agenda in public financial management.

To assist the authorities in the implementation of the Debt sustainability Analysis framework.

AFRITAC Micro finance February 11-15, supervision 2008

Segmentation of taxpayers, functionality of Syntax system and its implementation in the medium taxpayer Office.

Support personnel of microfinance supervision. 


\begin{tabular}{|c|c|c|c|}
\hline STA/PEM & $\begin{array}{l}\text { UEMOA } \\
\text { Directives }\end{array}$ & $\begin{array}{l}\text { February } 25-29, \\
2008\end{array}$ & $\begin{array}{l}\text { Support the preparation of the } \\
\text { revision of UEMOA directives. }\end{array}$ \\
\hline STA & $\begin{array}{l}\text { National } \\
\text { Accounts }\end{array}$ & April 14-25, 2008 & $\begin{array}{l}\text { Train staff in national accounts } \\
\text { software and improved compilation } \\
\text { techniques and tabulation } \\
\text { procedures. }\end{array}$ \\
\hline FAD & $\begin{array}{l}\text { Tax and } \\
\text { Customs } \\
\text { Administration } \\
\text { reforms }\end{array}$ & $\begin{array}{l}\text { June 1, 2008-April } \\
2009\end{array}$ & $\begin{array}{l}\text { Advise on tax and customs } \\
\text { administration reform strategy. }\end{array}$ \\
\hline FAD & $\begin{array}{l}\text { Modernization } \\
\text { of revenue } \\
\text { administration }\end{array}$ & May 1,2008 & $\begin{array}{l}\text { Advise on the modernization of } \\
\text { revenue administration. }\end{array}$ \\
\hline STA & $\begin{array}{l}\text { Real Sector } \\
\text { Statistics } \\
\text { Advisor }\end{array}$ & $\begin{array}{l}\text { December 26, } \\
\text { 2007-December } \\
31,2008\end{array}$ & $\begin{array}{l}\text { Advise on the compilation of real } \\
\text { sector statistics. }\end{array}$ \\
\hline FAD & $\begin{array}{l}\text { Public } \\
\text { Financial } \\
\text { Management }\end{array}$ & $\begin{array}{l}\text { April 29-May 11, } \\
2009\end{array}$ & $\begin{array}{l}\text { Advise on elaborating a strategy to } \\
\text { operationalize program budgeting. }\end{array}$ \\
\hline FAD & Tax Policy & $\begin{array}{l}\text { April 21-May 05, } \\
2009\end{array}$ & $\begin{array}{l}\text { Review and simplification of tax } \\
\text { system. }\end{array}$ \\
\hline AFRITAC & $\begin{array}{l}\text { Financial } \\
\text { Supervision }\end{array}$ & April 20-24, 2009 & $\begin{array}{l}\text { Improve the supervision of } \\
\text { microfinance institutions. }\end{array}$ \\
\hline $\mathrm{MCM}$ & $\begin{array}{l}\text { Sovereign Asset } \\
\text { and Liability } \\
\text { Management }\end{array}$ & $\begin{array}{l}\text { April 28-May 5, } \\
2009\end{array}$ & $\begin{array}{l}\text { Reinforcement of the capacity of } \\
\text { the national debt committee. }\end{array}$ \\
\hline AFRITAC & $\begin{array}{l}\text { Public } \\
\text { Expenditure } \\
\text { Management }\end{array}$ & $\begin{array}{l}\text { April 28-May 5, } \\
2009\end{array}$ & $\begin{array}{l}\text { Advise on public financial } \\
\text { management and public financial } \\
\text { statistics }\end{array}$ \\
\hline
\end{tabular}


STA

FAD

MCM

$\mathrm{MCM}$

Debt

Management

Tax Policy

Debt

management
December 7-14, 2009

February 8-12,

2010

March 15-19, 2010

January 18-22,

2010

AFRITAC

Public financial management

FAD

STA

FAD

FAD Tax

administration

Program

budgeting

Statistics

Public Financial April 26-May 13, Management 2010

2010

April 26-30, 2010
Assist in extending global Financial statistics coverage

Technical assistance in fiscal policy
TA Needs Assessment \& Evaluation of public debt management capacity

Improve public debt management capacity

March 15-26, 2010 Improve treasury cash management 


\begin{tabular}{|c|c|c|c|}
\hline FAD & $\begin{array}{l}\text { Public Financial } \\
\text { Management }\end{array}$ & $\begin{array}{l}\text { October } 25- \\
\text { November 5, } 2010\end{array}$ & $\begin{array}{l}\text { Improve the management of the } \\
\text { expenditure chain }\end{array}$ \\
\hline STA & Statistics & $\begin{array}{l}\text { December 13-17, } \\
2010\end{array}$ & Improve WAEMU statistics \\
\hline FAD & Customs & March 7-11, 2011 & Regional Workshop on customs \\
\hline FAD & $\begin{array}{l}\text { Tax } \\
\text { administration }\end{array}$ & June 1-14, 2011 & Taxation of the mining sector \\
\hline STA & $\begin{array}{l}\text { Public Financial } \\
\text { Management }\end{array}$ & $\begin{array}{l}\text { September 5-9, } \\
2011\end{array}$ & $\begin{array}{l}\text { Improve the processing of the Table } \\
\text { of Government Fiscal Operations }\end{array}$ \\
\hline AFRITAC & $\begin{array}{l}\text { Debt Strategy \& } \\
\text { Management }\end{array}$ & $\begin{array}{l}\text { October 17-21, } \\
2011\end{array}$ & $\begin{array}{l}\text { Establish a debt management } \\
\text { strategy }\end{array}$ \\
\hline AFRITAC & $\begin{array}{l}\text { Public } \\
\text { Expenditure } \\
\text { Management }\end{array}$ & $\begin{array}{l}\text { November 21, } \\
\text { December 2, } 2011\end{array}$ & $\begin{array}{l}\text { Strengthen expenditure } \\
\text { management }\end{array}$ \\
\hline
\end{tabular}

\section{Resident Representative:}

Ms. Isabell Adenauer took up the post of Resident Representative in June 2008. 


\section{Joint Management Action Plan (JMAP) Implementation}

(October 2011)

\begin{tabular}{|c|c|c|c|}
\hline Title & Products & $\begin{array}{l}\text { Provisional } \\
\text { timing of missions }\end{array}$ & $\begin{array}{l}\text { Expected } \\
\text { delivery date }\end{array}$ \\
\hline \multicolumn{4}{|c|}{ A. Mutual information on relevant work programs } \\
\hline \multirow{9}{*}{$\begin{array}{l}\text { Bank work program } \\
\text { in next } 12 \text { months }\end{array}$} & - Poverty Assessment & & March 2011 \\
\hline & - Public Expenditure Review (transport) & & February 2012 \\
\hline & - Mining sector study & & April 2012 \\
\hline & $\begin{array}{l}\text { - Policy Note on Growth and } \\
\text { Competitiveness }\end{array}$ & & June 2012 \\
\hline & - Poverty Assessment & ongoing & June 2012 \\
\hline & Technical Assistance & & \\
\hline & $\begin{array}{l}\text { - Support to the AICB to develop a weather } \\
\text { risk management strategy }\end{array}$ & & April-May 2012 \\
\hline & - Road map for decentralization (TA) & & $\begin{array}{l}\text { December } 2010- \\
\text { June } 2012\end{array}$ \\
\hline & $\begin{array}{l}\text { - Global Legal Information Network } \\
\text { implementation }\end{array}$ & & May 2012 \\
\hline \multirow{4}{*}{$\begin{array}{l}\text { IMF work program } \\
\text { in next } 12 \text { months }\end{array}$} & IMF-supported program: & & \\
\hline & - Third ECF review and Art IV. Mission & September 2011 & December 2011 \\
\hline & Technical Assistance & & \\
\hline & $\begin{array}{l}\text { - TA on tax policy and administration, and } \\
\text { customs }\end{array}$ & October 2011 & December 2011 \\
\hline \multicolumn{4}{|c|}{ B. Mutual requests } \\
\hline $\begin{array}{l}\text { Fund request to } \\
\text { Bank }\end{array}$ & $\begin{array}{l}\text { - Periodic update on progress with PRSC } \\
\text { - PER to provide quantitative inputs for } \\
\text { fiscal consolidation } \\
\text { - TA on windfall revenue management } \\
\text { - TA on parastatal restructuring } \\
\text { - TA on civil service reform }\end{array}$ & & \\
\hline $\begin{array}{l}\text { Bank request to } \\
\text { Fund }\end{array}$ & 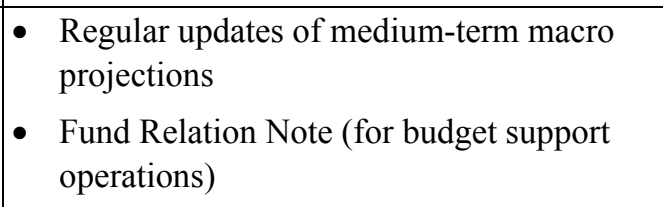 & & \\
\hline \multicolumn{4}{|c|}{ C. Agreement on joint products and missions } \\
\hline $\begin{array}{l}\text { Joint products in } \\
\text { next } \\
12 \text { months }\end{array}$ & $\begin{array}{l}\text { JSAN of the progress report of the } \\
\text { SCADD }\end{array}$ & March/April 2012 & June 2012 \\
\hline
\end{tabular}




\section{Statistical Issues}

\section{Burkina Faso-Statistical Issues Appendix (October 2011)}

\section{Assessment of Data Adequacy for Surveillance}

General: Data provision has some shortcomings, but is broadly adequate for surveillance. The most affected areas are: national accounts and price statistics. Burkina Faso has received technical assistance (TA) from the IMF; the TA has been partially financed by Japan.

National accounts: Annual GDP estimates are compiled by economic activity, by institutional sector accounts and by expenditure categories at current and constant prices $(1999=100)$. The quality of the national accounts estimates is affected by the scarcity of suitable data sources and by deficiencies in statistical practices. The informal sector is not properly captured - estimates are derived from limited surveys of the informal sector conducted in 1989 and 1996. An updating survey was envisaged in early 2011 but postponed because of the social unrest and funding requirements that could not be met. Most medium and small enterprises in the "modern sector" fall short of submitting accounting statements or tax declarations. Private household consumption is estimated as the residual and is not adequately validated with supply-use tables. These estimates are refined using results from the household budget-consumption surveys.

Price statistics: The CPI $(2008=100)$ only covers households living in the capital; it excludes non-African households, various types of purchased goods and services, and services of owner-occupied dwellings. The prices of unavailable products are presumed unchanged for a period of up to three months - best practice would impute a price change for these items based on the recorded prices changes for closely related products. Though the software package used for calculating the CPI has been overhauled in 2011, the authorities are planning for further improvements. The producer price index and the wholesale price index are not compiled and the development of these indices is still not envisaged because of budgetary constraints.

Government finance statistics: A committee was put in place to oversee the compilation of government finance statistics and strengthen coordination among fiscal agencies. The provision of expenditure data has also improved with the adoption of functional presentation of expenditure. The remaining areas for improvement include mainly the extension of the TOFE coverage to the general government and basing its compilation on the Treasury ledger.

Monetary finance statistics: Most of the problems in monetary statistics are not specific to Burkina Faso but affect all member countries of the WAEMU. The BCEAO has encountered difficulties in estimating currency in circulation in each WAEMU member country due to large backlogs of unsorted banknotes held by the central bank in its various national agencies. 
Balance of payments (BOP): The coverage of informal trade is incomplete. Improvements in the coverage of services and transfers (especially workers' remittances) depend on the intensification of contacts with reporting bodies. While the 2003 data ROSC mission found that the response rate for the survey among industrial and commercial enterprises was only 40 percent. Annual surveys, reporting foreign direct investment transactions, are conducted yearly, in line with requirements under the $6^{\text {th }}$ revision to the manual for the compilation of the BOP. To improve the quality of the BOP reports, the BCEAO authorities also plan to integrate two additional data sources: the regional stock exchange transactions and the firms' balance sheet database. However, the attempt to include data from regional stock exchanges was abandoned because of technical difficulties in monitoring intraday inflows and outflows by foreign nationals. The BCEAO authorities have indicated that quarterly data, derived from banking settlement reports, is used to assess BOP reports. BOP compilers receive payment statements every ten days. However, the information is not used in the compilation of the annual BOP statements, but rather to support data quality controls and to provide early information to the BCEAO authorities. The BCEAO will start publishing data on the international investment position of Burkina Faso with the adoption of the $6^{\text {th }}$ revision to the manual for the compilation of the BOP, and is therefore revising its surveys design and adapting its software accordingly. The launch of the new tools and procedures is expected for 2013.

\section{Data Standards and Quality}

Burkina Faso participates in the General Data

Dissemination Standard since December 28, 2001.
A data ROSC mission visited

Burkina Faso during May 8-21, 2003.

\section{Reporting to STA (Optional)}

Since October 2010, annual data and quarterly data covering budgetary central government are reported to STA for publication in International Financial Statistics and the Government Finance Statistics yearbook. The latest reported data cover 2010. The BCEAO reports monetary data to STA with a lag of at most three months. Despite requests, BOP and IIP data have not been reported to STA for publication in IFS and the BOPSY since 2001 


\section{Burkina Faso: Table of Common Indicators Required for Surveillance (October 2011)}

\begin{tabular}{|c|c|c|c|c|c|c|c|}
\hline & \multirow{2}{*}{$\begin{array}{c}\text { Date of } \\
\text { latest } \\
\text { observatio } \\
n\end{array}$} & \multirow{2}{*}{$\begin{array}{l}\text { Date } \\
\text { received }\end{array}$} & \multirow{2}{*}{$\begin{array}{c}\text { Frequency } \\
\text { of } \\
\text { Data }^{7}\end{array}$} & \multirow{2}{*}{$\begin{array}{l}\text { Frequency } \\
\quad \text { of } \\
\text { Reporting }^{7}\end{array}$} & \multirow{2}{*}{$\begin{array}{l}\text { Frequency } \\
\quad \text { of } \\
\text { Publication }^{7}\end{array}$} & \multicolumn{2}{|c|}{ Memo Items: ${ }^{8}$} \\
\hline & & & & & & $\begin{array}{l}\text { Data Quality - } \\
\text { Methodological } \\
\text { soundness }^{9}\end{array}$ & $\begin{array}{l}\text { Data Quality - } \\
\text { Accuracy and } \\
\text { reliability }^{10}\end{array}$ \\
\hline Exchange Rates & Current & Current & D & D & D & & \\
\hline $\begin{array}{l}\text { International Reserve Assets and Reserve } \\
\text { Liabilities of the Monetary Authorities }{ }^{1}\end{array}$ & $8 / 2011$ & 9/2011 & M & M & M & & \\
\hline Reserve/Base Money & $8 / 2011$ & 9/2011 & M & M & M & \multirow{4}{*}{ LO, LO, LNO, O } & \multirow{4}{*}{ LO, O, O, O, O } \\
\hline Broad Money & $8 / 2011$ & 9/2011 & M & M & M & & \\
\hline Central Bank Balance Sheet & $8 / 2011$ & 9/2011 & M & M & M & & \\
\hline $\begin{array}{l}\text { Consolidated Balance Sheet of the Banking } \\
\text { System }\end{array}$ & $8 / 2011$ & 9/2011 & M & M & M & & \\
\hline Interest Rates ${ }^{2}$ & $8 / 2011$ & 9/2011 & M & $M$ & M & & \\
\hline Consumer Price Index & $8 / 2011$ & 9/2011 & M & M & M & O, LNO, O, O & LNO, O, O, O, NA \\
\hline $\begin{array}{l}\text { Revenue, Expenditure, Balance and } \\
\text { Composition of Financing }^{3}-\text { General } \\
\text { Government }{ }^{4}\end{array}$ & 9/2011 & $10 / 2011$ & I & 1 & 1 & & \\
\hline $\begin{array}{l}\text { Revenue, Expenditure, Balance and } \\
\text { Composition of Financing }{ }^{3}-\text { Central Government }\end{array}$ & 9/2011 & $10 / 2011$ & M & M & M & O, LO, O, O & $\mathrm{O}, \mathrm{LO}, \mathrm{O}, \mathrm{O}, \mathrm{LNO}$ \\
\hline $\begin{array}{l}\text { Stocks of Central Government and Central } \\
\text { Government-Guaranteed Debt }{ }^{5}\end{array}$ & 9/2011 & $10 / 2011$ & A & A & A & & \\
\hline External Current Account Balance & 2009 & $10 / 2011$ & A & A & A & & \\
\hline Exports and Imports of Goods and Services & 2009 & $10 / 2011$ & A & A & A & $\mathrm{O}, \mathrm{O}, \mathrm{O}, \mathrm{O}$ & LO, O, LO, O, O \\
\hline GDP/GNP & 2009 & $10 / 2011$ & A & A & A & $\begin{array}{l}\text { LO, LNO, LNO, } \\
\text { LO }\end{array}$ & $\begin{array}{l}\text { LNO, LNO, LO, } \\
\text { LO, LNO }\end{array}$ \\
\hline Gross External Debt & 9/2011 & $10 / 2011$ & A & A & A & & \\
\hline International Investment Position ${ }^{6}$ & $12 / 2009$ & $3 / 2010$ & A & A & $A$ & & \\
\hline
\end{tabular}


${ }^{1}$ Any reserve assets that are pledged or otherwise encumbered should be specified separately. Also, data should comprise short-term liabilities linked to a foreign currency but settled by other means as well as the notional values of financial derivatives to pay and to receive foreign currency, including those linked to a foreign currency but settled by other means.

${ }^{2}$ Both market-based and officially-determined, including discount rates, money market rates, rates on treasury bills, notes and bonds.

${ }^{3}$ Foreign, domestic bank, and domestic nonbank financing.

${ }^{4}$ The general government consists of the central government (budgetary funds, extra budgetary funds, and social security funds) and state and local governments.

5 Including currency and maturity composition.

${ }^{6}$ Includes external gross financial asset and liability positions vis-à-vis nonresidents.

${ }^{7}$ Daily (D); weekly (W); monthly (M); quarterly (Q); annually (A); irregular (I); and not available (NA).

${ }^{8}$ These columns should only be included for countries for which Data ROSC (or a Substantive Update) has been published.

${ }^{9}$ Reflects the assessment provided in the data ROSC or the Substantive Update (published on March 10, 2004, and based on the findings of the mission that took place during

May 8-21, 2003) for the dataset corresponding to the variable in each row. The assessment indicates whether international standards concerning concepts and definitions, scope, classification/sectorization, and basis for recording, respectively, are fully observed (O); largely observed (LO); largely not observed (LNO); not observed (NO); and not available (NA).

${ }^{10}$ Same as footnote 9, except referring to international standards concerning, respectively, source data, assessment of source data, statistical techniques, assessment and validation of intermediate data and statistical outputs, and revision studies. 
Public Information Notice (PIN) No. 11/162

FOR IMMEDIATE RELEASE

December 27, 2011
International Monetary Fund

$70019^{\text {th }}$ Street, NW

Washington, D. C. 20431 USA

\section{IMF Executive Board Concludes 2011 Article IV Consultation with Burkina Faso}

On December 21, 2011, the Executive Board of the International Monetary Fund (IMF) concluded the Article IV consultation with Burkina Faso. ${ }^{1}$

\section{Background}

Sustained implementation of sound policies and reforms in recent years, as well as strong performance in key sectors driving growth helped the Burkinabè economy withstand several exogenous shocks in 2008-10. Economic growth has been robust; inflation has been trending down since the flare-up in 2008 caused by the global food and fuel prices; and the external current account deficit has narrowed, mostly reflecting the significant increase in gold exports. The authorities have maintained fiscal consolidation efforts, while mitigating the impact of exogenous shocks, and enhancing poverty reduction programs. In the later area, the authorities implemented a number of initiatives and took measures to support vulnerable groups. Key programs included school lunches, support to the elderly, and a cash transfer program. During 2001-10, the share of poverty reducing spending in total expenditure rose from 17.5 to 28 percent. These efforts were aided by progress in revenue mobilization and financial support from Burkina Faso's development partners.

\footnotetext{
${ }^{1}$ Under Article IV of the IMF's Articles of Agreement, the IMF holds bilateral discussions with members, usually every year. A staff team visits the country, collects economic and financial information, and discusses with officials the country's economic developments and policies. On return to headquarters, the staff prepares a report, which forms the basis for discussion by the Executive Board. At the conclusion of the discussion, the Managing Director, as Chairman of the Board, summarizes the views of Executive Directors, and this summary is transmitted to the country's authorities. An explanation of any qualifiers used in summings up can be found here: http://www.imf.org/external/np/sec/misc/qualifiers.htm.
} 
The authorities made important progress in implementing structural reforms in recent years, particularly in revenue collection, expenditure and Treasury cash flow management, cotton sector rehabilitation, the business environment, and the financial sector. In the later area, the authorities prepared strategies for the development of the financial and microfinance sectors, and implemented a divesture and rehabilitation program for selected banks. They continue to seek funding for the efficient implementation of the financial sector strategy. The authorities have also maintained a prudent borrowing policy, consistent with debt sustainability analysis that points to a high risk of debt distress for Burkina Faso.

In 2011, economic growth is projected at 5.6 percent, from7.9 percent in 2010 , mostly driven by an expansion in the agriculture and mining sectors, which were marginally affected by the social turmoil and exogenous shocks in the first half of the year. Thanks to a good harvest, inflation is estimated to average 1.4 percent. The external current account (including grants) is projected to stabilize around 31/2 percent of GDP, benefitting from the projected improvement in terms of trade; and the overall fiscal deficit (excluding grants) would increase to 10.9 percent of GDP, from10.1 percent of GDP in 2010, partly reflecting measures taken by the authorities to address adverse shocks in 2011.

The medium-term outlook is promising. Economic growth is forecast to reach 6.4 percent by 2013 , thanks to the programmed public investment scaling-up, particularly in infrastructure; continued structural reforms; and the projected expansion in the mining sector. Inflation is expected to remain below 3 percent, thus complying with the West African Economic and Monetary Union (WAEMU) convergence criterion. The external current account deficit is projected to widen from 8.2 percent of GDP in 2011 to 10.9 percent in 2013, mainly because imports demand is expected to remain strong and to grow faster than exports in 2012-13. With continued measures to enhance revenue mobilization and expenditure management, the fiscal position is projected to improve in 2012 and over the medium-term, with the overall deficit declining from 10.9 percent of GDP in 2011 to 9 percent in 2013, notwithstanding an increase in investment and propoor spending.

Key risks to the economic outlook are related to the economy's vulnerability to terms of trade shocks that might affect commodity prices, particularly for cotton, gold, and oil; and adverse changes to climatic conditions that would weaken growth prospects. 


\section{Executive Board Assessment}

Executive Directors welcomed the authorities' sustained implementation of sound policies and structural reforms, which has contributed to robust economic growth, low inflation, and a broadly favorable external position. They noted, however, that global uncertainties and climatic conditions pose downside risks to the near-term outlook. In addition, daunting macroeconomic challenges remain, and poverty is still widespread. Directors underscored that continued fiscal consolidation, improved social policies, and decisive implementation of structural reforms will be critical to achieve sustained, broad-based economic growth and poverty reduction.

Directors encouraged the authorities to maintain fiscal discipline within the context of a medium-term fiscal framework, while increasing investment and social spending. They welcomed the continued focus on revenue mobilization to boost domestic resource availability. Directors also emphasized the need to strengthen expenditure management, contain current spending, and increase targeted poverty-related spending. In particular, they underscored that wage policy should remain prudent and supportive of medium-term fiscal objectives, and they encouraged full pass-through of international fuel price movements to domestic fuel prices.

Directors agreed with the authorities' focus on scaling up investment to close the infrastructure gap and boost economic growth. Nevertheless, they stressed the need to improve investment efficiency, and to ensure that investment financing strategies are consistent with long-term debt sustainability. They noted that Burkina Faso remains at a high risk of debt distress, and called for continued prudent debt management anchored on grants and highly concessional loans.

Directors stressed that further progress on structural reforms will be critical to enhance competitiveness and stimulate broad-based economic growth. They highlighted the importance of reforms to improve the business environment and support private sector development, including strengthening the regulatory and judicial framework. Continued rehabilitation of the cotton sector will be crucial. Directors also urged acceleration of financial sector reforms to reduce financial sector vulnerabilities and to broaden access to financial services.

Public Information Notices (PINs) form part of the IMF's efforts to promote transparency of the IMF's views and analysis of economic developments and policies. With the consent of the country (or countries) concerned, PINs are issued after Executive Board discussions of Article IV consultations with member countries, of its surveillance of developments at the regional level, of post-program monitoring, and of ex post assessments of member countries with longer-term program engagements. PINs are also issued after Executive Board discussions of general policy matters, unless otherwise decided by the Executive Board in a particular case. 
Burkina Faso: Selected Economic Indicators, 2009-13

\begin{tabular}{|c|c|c|c|c|c|}
\hline & 2009 & 2010 & 2011 & 2012 & 2013 \\
\hline & & Est. & Proj. & Proj. & Proj. \\
\hline & \multicolumn{5}{|c|}{$\begin{array}{l}\text { (Annual percentage change; unless } \\
\text { otherwise indicated) }\end{array}$} \\
\hline \multicolumn{6}{|l|}{ GDP and prices } \\
\hline GDP at constant prices & 3.2 & 7.9 & 5.6 & 5.8 & 6.4 \\
\hline Consumer prices (annual average) & 2.6 & -0.6 & 1.9 & 2.0 & 2.0 \\
\hline \multicolumn{6}{|l|}{ Money and credit } \\
\hline Credit to the economy ${ }^{1}$ & 1.2 & 8.9 & 3.1 & 11.0 & 6.4 \\
\hline Broad money (M2) & 18.2 & 19.1 & 19.1 & 13.6 & 8.5 \\
\hline \multicolumn{6}{|l|}{ External sector } \\
\hline Terms of trade & 19.2 & 0.1 & 12.2 & 6.4 & -1.9 \\
\hline Real effective exchange rate $(-$ sign $=$ & 2.6 & -8.4 & $\ldots$ & $\ldots$ & $\ldots$ \\
\hline
\end{tabular}

Central government finances

Domestic revenue

Total expenditure (commitment basis)

$\begin{array}{rrrrr}13.7 & 15.6 & 15.8 & 16.2 & 16.3 \\ 24.4 & 25.7 & 26.7 & 26.1 & 25.3 \\ -10.7 & -10.1 & -10.9 & -9.9 & -9.0 \\ -4.8 & -5.6 & -3.9 & -3.0 & -2.6\end{array}$

Overall fiscal balance, incl. grants (commitments)

External sector and debt indicators

Exports of goods and services

Imports of goods and services

Current account balance (incl. current official

$\begin{array}{rrrrr}12.4 & 18.1 & 24.1 & 24.6 & 24.4 \\ 23.3 & 27.2 & 33.9 & 36.0 & 36.6 \\ -4.4 & -3.6 & -3.5 & -6.9 & -7.6 \\ -8.8 & -7.5 & -8.2 & -9.9 & -10.9 \\ 18.6 & 21.5 & 23.0 & 23.4 & 24.4 \\ 13.2 & 16.4 & 17.0 & 17.1 & 17.5 \\ 107.0 & 90.2 & 70.8 & 69.4 & 71.8 \\ 98.6 & 104.8 & 107.8 & 105 . & 107.7\end{array}$

Current account balance (excl. current official

External debt

NPV of external debt

NPV of external debt as percent of exports

NPV of external debt as percent of revenues

Sources: Burkinabè authorities and IMF staff estimates and projections.

${ }^{1}$ Percent of beginning-of-period broad money. 
December 21, 2011

\section{IMF Executive Board Completes Third Review Under ECF Arrangement for Burkina Faso and Approves US\$9.95 Million Disbursement}

The Executive Board of the International Monetary Fund (IMF) today completed the third review of Burkina Faso's economic performance under the program supported by the Extended Credit Facility (ECF). The completion of the review will enable the disbursement of an amount equivalent to SDR 6.45 million (about US\$9.95 million), bringing total disbursements under the arrangement to SDR 26.804 million (about US\$41.36 million).

The three-year ECF Arrangement for Burkina Faso was approved by the Board on June 14, 2010 (See Press Release No. 10/241). The Executive Board also concluded the 2011 Article IV consultation with Burkina Faso today. A Public Information Notice will be published in due course.

Following the Executive Board's discussion on Burkina Faso, Mr. Min Zhu, Deputy Managing Director and Acting Chair, issued the following statement:

"The Burkinabè authorities are to be commended for their steadfast implementation of policies and reforms supportive of macroeconomic stability and economic growth, despite a difficult social environment. Good performance in the agriculture, mining and services sectors have supported economic growth and price stability despite adverse trade and weather shocks. In addition, increased export production and prices have strengthened Burkina Faso's external position in recent years.

“The Burkinabè authorities' continued efforts to enhance revenue collection have increased fiscal space for much needed public investment and priority social spending. The authorities need to enhance these efforts and advance public financial management reforms to support medium-term fiscal consolidation.

"To build on recent progress and enhance medium-term prospects, the Burkinabè authorities will need to maintain the momentum of structural reforms to diversify economic activity and enhance competitiveness. In particular, they will need to push ahead with measures aimed at 
reducing transaction costs for the private sector, supporting financial sustainability in the cotton sector, and improving the business climate. Implementation of the financial sector development strategy should be accelerated, with a view to broadening access to financial services for small and medium-size enterprises.

"The ambitious public investment program underway, in accordance with the new Poverty Reduction Strategy Paper, is critical to reduce the infrastructure gap and support broad-based growth. However, financing options for the investment budget will have to be weighed carefully, taking into account Burkina Faso's high risk of debt distress.

"In view of the Burkinabè economy's vulnerability to exogenous shocks that affect the most vulnerable in the population, the authorities need to place special emphasis on the preparation of a social safety net." 


\section{Statement by Mr. Assimaidou on Burkina Faso \\ Executive Board Meeting \\ December 21, 2011}

On behalf of my Burkinabè authorities, I thank staff for their constructive engagement and the valuable policy advice provided during the ECF program review and 2011 Article IV discussions held in Ouagadougou in October 2011, as well as through technical assistance.

In spite of a difficult social and regional environment in the first half of the year, the authorities stayed the course in implementing the economic and financial program supported by the Fund under the Extended Credit Facility. All quantitative performance criteria and all indicative targets except the one on poverty reduction spending were met. Most structural reforms benchmarks were also achieved. Substantial progress has been made towards meeting the few unmet benchmarks.

The implementation of sound policies helped the authorities mitigate the impact of the severe exogenous shocks, including increased commodities and fuel prices, disruptions in the supply of electricity and trade, reflecting a sub-regional crisis, and social disquiet. They also made inroads in poverty reduction and growth promotion, while ensuring macroeconomic stability. Notwithstanding the progress achieved, the authorities are cognizant of the difficult challenges ahead, particularly in achieving the millennium development goals, accelerating growth, and diversifying the economy in line with their poverty reduction strategy (SCADD).

They are committed to continue the reform program, in close consultation with their development partners, and with the IMF.

\section{Recent Economic Development}

In spite of the difficult environment, the real sector registered a strong performance driven mostly by the mining and cotton sectors. Real GDP growth is projected to reach 5.6 percent in 2011, and inflation at 1.4 percent, significantly below the 3 percent regional convergence criterion. The current account position strengthened on account of improved terms of trade and aid inflows.

The authorities maintained a prudent fiscal policy stance, thus creating the fiscal space needed to mitigate the impact of the shocks and promote growth, while ensuring fiscal sustainability. The fiscal targets were achieved by improving revenue collections, strengthening expenditure controls, and through public management reforms.

The revenue enhancing measures undertaken included closer monitoring of large taxpayers, and an anti-fraud campaign in the customs offices. On spending, the authorities sought to improve the quality of expenditures and remedy weaknesses in budget execution, including through the installment of expenditure verification units in line ministries, the completion of the audit of finance and administrative units, and the implementation of an integrated monitoring system for external financing. 
While revenues collected were comfortably higher than projected, expenditure execution was under-performing, reflecting the social unrest in the first half of the year, and delays in the procurement process. A mid-year budget execution review made recommendations to address the identified weaknesses, which the authorities sought to implement. In this vein, the government deliberated this week on a capacity building strategy for procurement officers, which aims at increasing the efficiency of public spending by training procurement personnel in international best-practices.

In order to strengthen further their fiscal framework, the authorities made steadfast progress towards the adoption of program budgeting framework, and to internalize regional fiscal directives, which will increase transparency in the budget.

The authorities sough to consolidate debt sustainability by systematically seeking grants and concessional financing, and taking steps to strengthen debt management capabilities. They prepared an action plan to address the vulnerabilities identified by the March 2011 World Bank's Debt Management Performance Assessment (DeMPA), and held training sessions for the debt unit personnel in the new borrowing and debt management procedures.

On structural reforms, the authorities made progress in improving the business environment and in implementing their financial sector development strategy. Amongst others, they overhauled the supervisory framework for the insurance industry, and undertook steps towards the finalization of a microfinance strategy.

Regarding the cotton sector, they sought to strengthen the management of the main cotton ginning company SOFITEX, and implemented the main recommendations of the report on the cotton price-smoothing fund.

\section{Economic Policies for 2012}

Looking forward, the authorities will focus their efforts on addressing the pressing needs of the populations, and in implementing their SCADD strategy to accelerate growth and reduce poverty. To implement their ambitious reform agenda, they will seek to mobilize additional resources both internally and externally, with a scaling up of donors' support.

\section{Fiscal policy}

As reflected in the 2012 budget recently adopted by parliament, the authorities will intensify their efforts to mobilize revenues, and increase spending allocated to priority sectors, while ensuring of fiscal sustainability. They plan to increase revenue collections to 16.2 percent of GDP during the fiscal year 2012, notably by pursing reforms in the customs and revenues administrations units, and implementing the new taxation regime.

As regards spending, the authorities' reforms will seek to improve expenditure controls, and spending efficiency. They plan to increase spending in priority sectors, particularly on growth enhancing capital expenditure, while reducing current expenditure. Efforts to remedy the identified weaknesses in the execution of the budget will also be pursued.

The authorities will also continue the efforts to reduce poverty, through a strengthening of the social safety net, and initiate a youth and women's employment program. In line with 
the agreement reached with the labor unions following social unrests earlier this year, the authorities plan to increase the civil service base salary by 5 percent and regularize benefits in order to reduce inequities in the compensation system. Mindful of the need to preserve medium term fiscal sustainability, the authorities will accelerate their civil service reform agenda, which will help control the wage bill in the medium term.

On debt policies, the authorities are committed to the preservation of debt sustainability. They welcome the Debt Sustainability Analysis's results, which noted improvements in Burkina's debt outlook. The report also highlighted the prudent borrowing strategy pursued by the authorities, with external debt representing 20 percent of GDP, and domestic borrowing 2.6 percent of GDP. Nonetheless, the authorities plan to continue to strengthen their debt management capabilities, in line with the World Bank's DeMPA's recommendations. They will also pursue efforts to diversify the countries' exports.

\section{Financial sector reforms}

In the financial sector, the authorities plan to intensify reforms in line with their financial sector development strategy. In this vein, they will strengthen the regulation of the microfinance sector, with the view to improving SME, and household's access to financial services. They will also promote competition in the financial sector, including by reducing the state's share in the banking sector.

\section{Structural Reforms}

The authorities' structural reforms agenda will be two-pronged, seeking to broaden the sources of growth, and to build up human capital. To broaden the sources of growth and diversify the economy, the authorities will continue their efforts to eliminate infrastructure bottlenecks. They will also launch a pilot regional growth cluster project.

My Burkinabè authorities will seek to promote a private sector-led growth, by continuing to take measures to improve the climate for business, and administrative efficiency. To that purpose, a legal framework to develop public-private partnerships will be put in place, as well as an agency for the promotion of investments.

In the cotton sector, the authorities will move forward in the implementation of the sector's strategy. In light of the increasing share of natural resources in Burkina Faso's growth, the authorities plan to adopt a new mining code, and regulation in keeping with international standards, and to remain in compliance with the EITI Rules.

\section{Conclusion}

In light of the authorities continued track record of strong program implementation, and their commitment to sound policies going forward in addressing the countries poverty reduction and development challenges, I call on Director's support to the authorities request for the completion of the third review of the ECF arrangement. 